Luciana Nobre de Abreu

\title{
Textos de divulgação cientifica no ensino superior de química: funcionamento e produção de sentidos
}

Dissertação apresentada ao Instituto de Química de São Carlos, da Universidade de São Paulo para obtenção do título de Mestre em Ciências (Química Analítica)

Orientadora: Prof. Dr. Salete Linhares Queiroz 


\section{DEDICATÓRIA}

Aos meus pais, Francisco e Expedita - in memoriam -, irmãs, Lilian e

Leydiane e marido, Jerino, pelo amor e dedicação indispensáveis à minha existência.

Em especial à minha mãe Expedita, cujos valiosos ensinamentos continuam a se fazer presentes em todos os momentos de minha vida, mesmo após sua partida. 


\section{AGRADECIMENTOS}

Ao Instituto de Química de São Carlos, da Universidade de São Paulo, pela estrutura oferecida ao Mestrado.

Ao CNPq, pelo financiamento da Bolsa de Estudos.

À Profa. Dra. Salete Linhares Queiroz, pela confiança, orientação segura, generosidade intelectual e presteza em indicar os caminhos.

Ao professor Hidetake Imasato e aos alunos participantes desta pesquisa, pela paciência e disposição no decorrer da aplicação da proposta de ensino.

À Profa. Dra. Vanice Maria Oliveira Sargentini, pelas preciosas contribuições no entendimento dos referenciais teóricos que guiaram esta pesquisa.

À Profa. Dra. Ruth de Gouvêa Duarte, pela lição de vida.

Aos funcionários do Instituto de Química de São Carlos, em especial à Sílvia e Andréia, pela cordialidade no atendimento.

Aos colegas do Grupo de Pesquisa em Ensino de Química, pelas agradáveis conversas na "salinha" e pela troca fecunda de conhecimentos durante as reuniões.

Ao meu amado marido, Jerino, pelo amor, companheirismo e compreensão, não somente no período de realização deste trabalho, mas em todos os momentos de nossa vida juntos.

Ao meu pai, Francisco, minhas irmãs, Lilian e Leydiane, e minha sobrinha e afilhada Júlia, pelos reconfortantes telefonemas e e-mails nos momentos de forte saudade.

Aos amigos Rafael e Luciana Sá, pela acolhida e apoio desde a nossa chegada em São Carlos e Edjane, pela constante amizade.

À amiga Luciana Massi, pela parceria nas primeiras tentativas de análise dos dados desta dissertação.

A todos que contribuíram direta ou indiretamente para a realização deste trabalho. 
"Quando existe avanço tecnológico sem avanço social, surge quase automaticamente, um aumento da miséria humana."

Michael Harrington (1928 - 1989) 


\section{RESUMO}

A utilização de textos de divulgação científica no ensino formal tem sido discutida por pesquisadores da área de educação em ciências. Tais discussões sugerem que esses textos podem funcionar como instrumento de motivação em sala de aula, organizando explicações e estimulando debates de modo a ampliar o universo discursivo dos estudantes. Nesta perspectiva, foi aplicada uma proposta de ensino pautada no uso de textos extraídos do livro de divulgação científica Tio Tungstênio: Memórias de uma Infância Química, de Oliver Sacks. O objetivo da proposta foi investigar o funcionamento de tais textos, a produção de sentidos por eles proporcionada e suas contribuições para o ensino superior de química. A proposta, que envolveu a produção de textos e elaboração de perguntas pelos alunos sobre conteúdos presentes no livro, foi aplicada em uma disciplina oferecida a estudantes de graduação em química. Os dados obtidos foram analisados segundo a Análise do Discurso de linha francesa, como tem sido divulgada por Eni Orlandi, especialmente as noções de tipologia do discurso e autoria. A análise dos resultados com relação à tipologia revelou, nas questões formuladas pelos alunos, deslocamentos do discurso pedagógico, predominantemente autoritário, para um discurso polêmico. Quanto à autoria, na produção dos textos, foi percebida a utilização de três tipos de repetição - empírica, formal e histórica. A maioria dos alunos fez uso da repetição histórica, tipo de repetição que indica o posicionamento dos alunos como autores de seus textos. A análise dos resultados indicou que os textos de divulgação científica funcionaram como mediadores para a colocação de 
posicionamentos incomuns em aulas tradicionais do ensino superior de química, o que sugere a viabilidade da proposta neste nível de ensino. 


\section{ABSTRACT}

The use of scientific divulgation texts in formal education has been discussed by researchers in the field of Science Education. Such discussions suggest that these texts can be an instrument of motivation in the classroom organizing explanations and stimulating discussions in order to expand the students discursive universe. Thus, a teaching proposal was implemented based on the book Uncle Tungsten: Memories of a Chemical Boyhood, by Oliver Sacks. The goal of this proposal was to investigate its understanding, acceptance, and contributions to undergraduate chemistry teaching. The study involved the production of texts and questions by the students about some chapters of that book. The data were analyzed by Discourse Analysis, in its French approach, according to Eni Orlandi, especially the concepts of discourse typology and authorship. The typology results demonstrated transitions from a pedagogic discourse, predominantly authoritarian, to a polemical discourse. The authorship results indicated the use of the three different kinds of repetition (empirical, formal and historical). The historical repetition use demonstrates that the majority of the students played the role of authors. Hence, the scientific divulgation texts act as mediators for nontraditional remarks by the students in undergraduate chemistry classes, suggesting the feasibility of this proposal at this level of education. 


\section{SUMÁRIO}

\section{RESUMO}

\section{ABSTRACT}

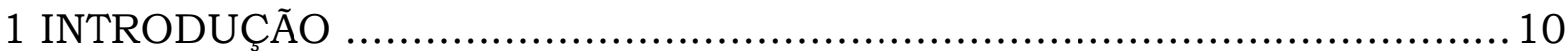

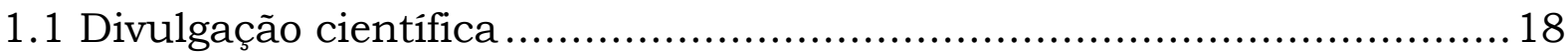

1.2 Textos de divulgação científica no ensino de ciências ........................22

1.3 Tio Tungstênio: memórias de uma infância química ...........................42

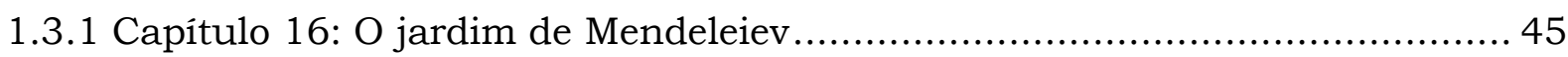

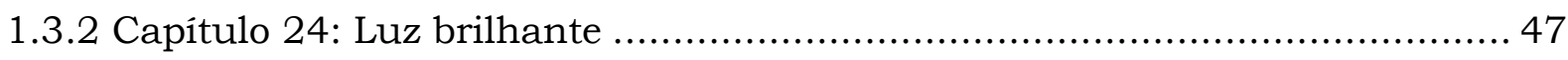

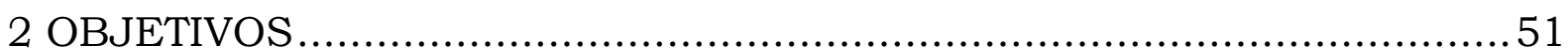

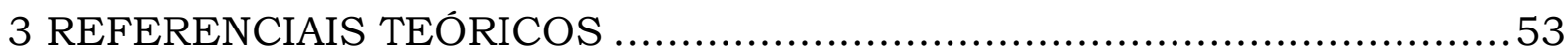

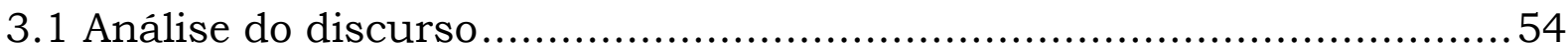

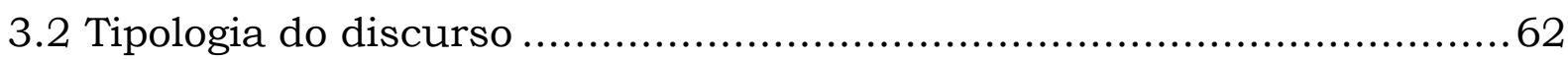

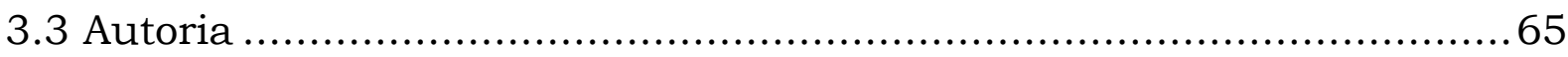

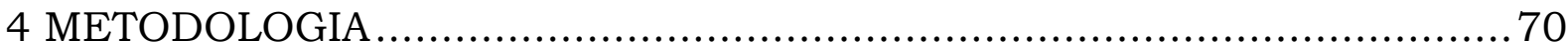

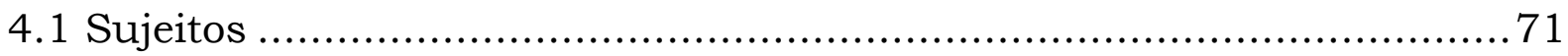

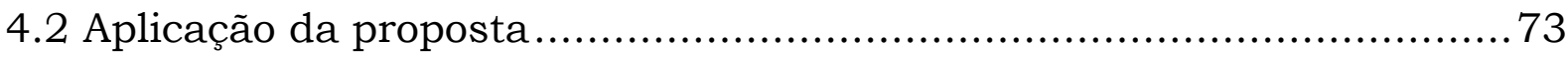

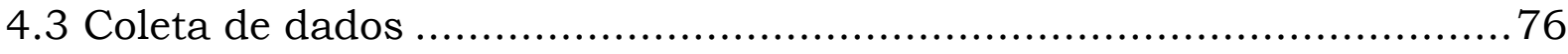

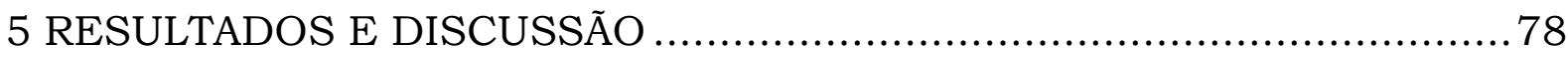

5.1 Questões formuladas pelos estudantes .............................................

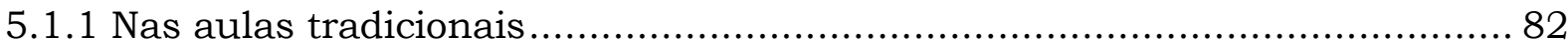

5.1.2 Nas atividades com os textos de divulgação científica................................. 85

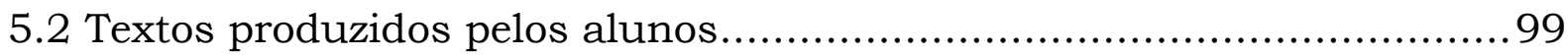

5.2.1 Análise dos textos com predominância de repetição histórica..................... 102

5.2.2 Análise dos textos com predominância de repetição formal ....................... 122

5.2.3 Considerações sobre os textos com predominância de repetição empírica .. 125

5.3 Percepções dos alunos sobre a proposta de ensino aplicada .............. 127

5.3.1 Impressões iniciais dos alunos com relação à leitura do livro ..................... 128

5.3.2 Impressões dos alunos a respeito da primeira atividade ........................... 130

5.3.3 Impressões dos alunos a respeito da segunda atividade ............................ 132

5.3.4 Impressões dos alunos com relação ao processo de aplicação da proposta . 133

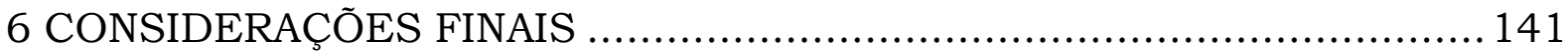

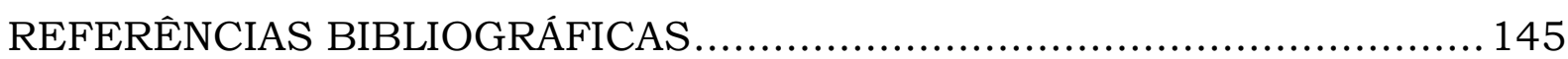

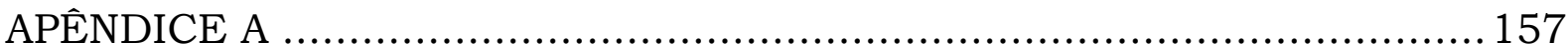




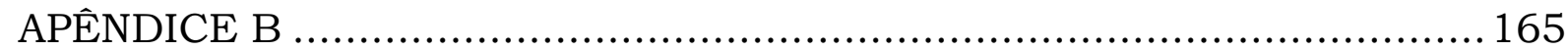

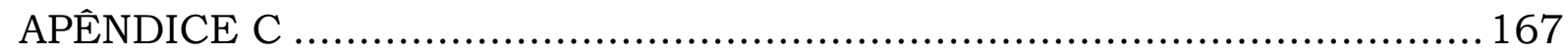

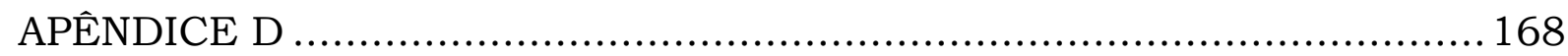

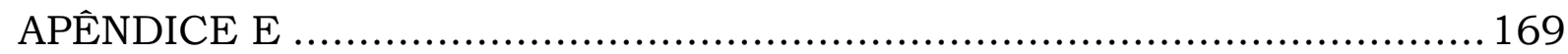

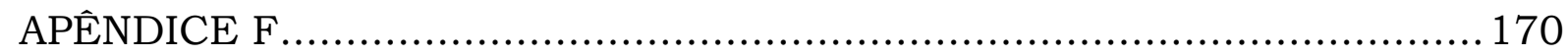

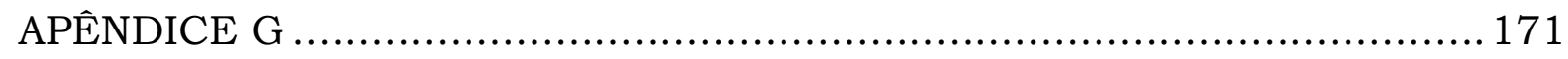

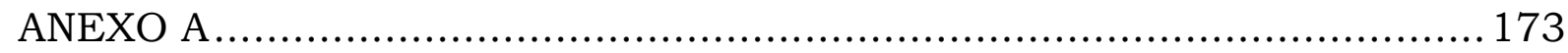

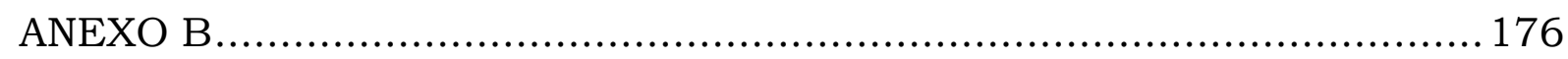

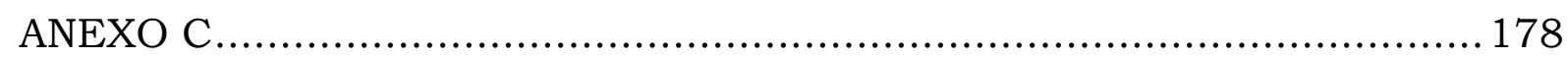

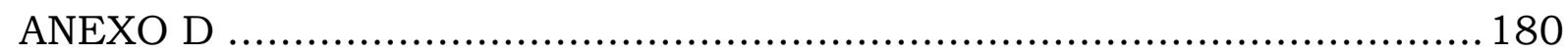

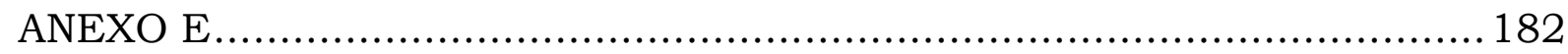

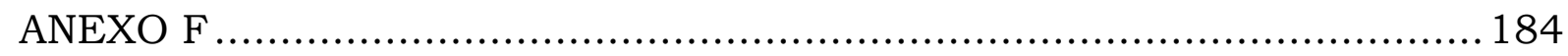

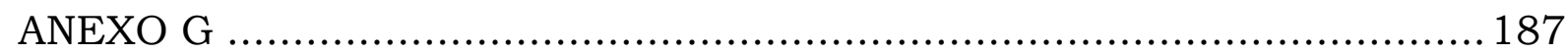

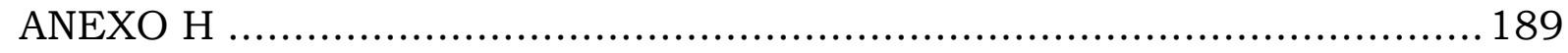

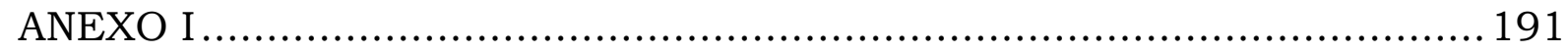

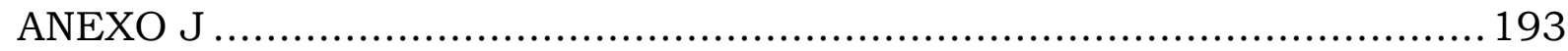

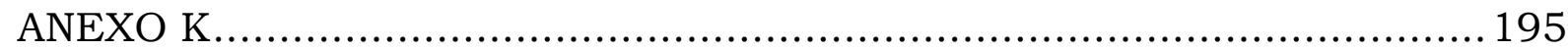

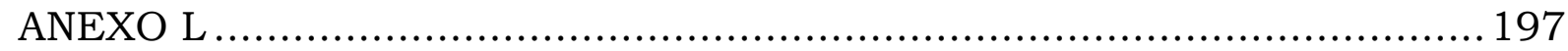

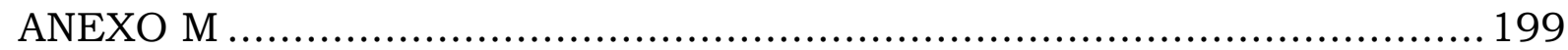

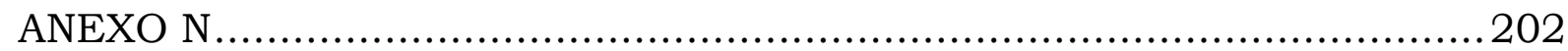

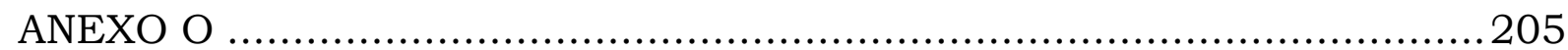

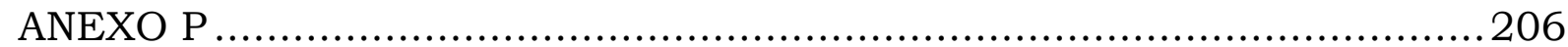




\section{INTRODUÇÃO}

Nos últimos anos tem havido crescente preocupação por parte de educadores que se dedicam ao ensino superior de química com relação à necessidade de adoção de estratégias/ações que privilegiem o papel do aluno no processo de ensino-aprendizagem dessa disciplina (WHELAN; ZARE, 2003; SÁ; QUEIROZ, 2007; ZANON; ALMEIDA; QUEIROZ, 2007). Tais preocupações, que orientam a construção e a concretização de propostas curriculares no mundo inteiro, enfatizam a importância do oferecimento de uma formação mais geral aos graduandos e a relevância do estímulo ao desenvolvimento de um caráter crítico-reflexivo dos mesmos (COPOLLA; EGE; LAWTON, 1997). No Brasil, as Diretrizes Curriculares para os Cursos de Química apontam nessa direção quando explicitam:

A necessidade de uma flexibilização curricular que, sem prejuízo de uma formação didática, científica e tecnológica sólida, avance também na direção de uma formação humanística que dê condições ao egresso de exercer a profissão em defesa da vida, do ambiente e do bem-estar do cidadão (ZUCCO; PESSINE; ANDRADE, 1999, p.454). 
Este enfoque humanista, apregoado nas Diretrizes Curriculares, caracteriza-se por centrar os estudantes no desenvolvimento de sua identidade cultural e pessoal, incentivando-os a participarem como cidadãos na sociedade e a se interessarem por dar sentido pessoal e social ao conhecimento da ciência e da tecnologia. Segundo Vázquez-Alonso, Acevedo-Diaz e Mas (2005), a educação científica deve alcançar sua integração em contextos culturais específicos e contribuir na redução da brecha entre as culturas científica e humanística. Isso implica em proporcionar uma imagem mais ajustada da realidade atual da natureza humana, cultural e social da ciência e, deste modo, desenvolver uma sensibilidade crítica acerca dos impactos sociais e ambientais causados por ela e educar para a participação pública na sua avaliação e controle.

Os mesmos autores afirmam, ainda, que a escola faz uma divisão entre matérias humanísticas e científico-tecnológicas, como se estas fossem opostas. De acordo com Donnelly (2004), as humanidades se caracterizam por quatro traços principais:

i) Educação para a autonomia pessoal e a capacidade de realizar juízos e interpretações independentes;

ii) Indeterminação da própria matéria;

iii) Busca do sentido integral no marco das relações humanas;

iv) Possibilidade de coincidências no juízo, face ao relativismo que supõe a indeterminação.

Em suas origens, a ciência formava parte das humanidades, mas sua posterior institucionalização e profissionalização deram lugar a um 
distanciamento progressivo, que fincou ainda mais as diferenças e contrastes, que foi fulminando o caráter humano da ciência (ALFONSO-GOLDFARB, 1995). Assim, considera-se somente que as ciências são, sobretudo, racionalistas e não têm em conta as emoções, os sentimentos, a moral e a história, enquanto que as humanidades estão situadas no pólo oposto. Esta separação tem contribuído para a criação do mito cientificista e da imagem autoritária e fechada da ciência, que estariam na base do ensino de ciências tradicional.

Em consonância com as idéias apresentadas anteriormente, entendemos a importância de levar esse caráter humanista ao ensino superior de química, para que os estudantes a reconheçam como uma construção humana, compreendam os aspectos históricos de sua produção e suas relações com os contextos cultural, socioeconômico e político. A partir desta premissa, compartilhamos, com um universo variado de profissionais, a preocupação em contribuir na formação do leitor. Não somente contribuir para a aquisição do hábito da leitura ou dar condições para que o leitor sinta prazer nessa atividade mas, também, e mais importante ainda é auxiliar na construção de leitores críticos. Para Gama (2005), o indivíduo só se torna cidadão quando possui consciência de sua participação social. A autora acrescenta ainda:

A linguagem inquestionavelmente permeia todas as práticas sociais e comunicativas, uma vez que essas se formam na interação entre os homens. Sendo assim, o indivíduo certamente está mais apto para as diferentes práticas sociais e para exercer a sua cidadania quando se situa nos diversos contextos e, em nossa sociedade para isso, necessariamente, é preciso saber ler. A participação nos mundos da escrita, o que implicitamente traz como fundamental os gestos da leitura, é condição básica para a concretização da cidadania (GAMA, 2005, p.1-2). 
Dentro da abrangência da questão da formação do leitor está uma mais específica e de maior interesse neste trabalho: a formação do leitor de ciência. Segundo Silva (2002), a leitura surge como um conceito fundamental na análise das interações entre textos e sujeitos; ela é vista não somente como um meio de organizar os conceitos científicos mas, também, as interações sociais entre professores, seus alunos e a comunidade escolar. Deste modo, atividades de leitura poderiam contribuir para diminuir o distanciamento entre o aluno e o conhecimento científico, o qual, muitas vezes, reflete e reforça uma falta de motivação para seu aprendizado.

Gama (2005) frisa que ao nos preocuparmos com a formação de leitores de ciência demonstramos interesse em contribuir para a formação de cidadãos que tenham conhecimento suficiente para compreender e questionar a ciência de seu tempo, conscientes da necessidade de relacionar os avanços tecnológicos ao contexto histórico-social em que vivem, entender notícias de teor científico e saber lidar com informações do campo científico como é necessário que lidem com as de qualquer outra área.

Neste contexto, destacamos as considerações de Martins, Cassab e Rocha (2001). Esses autores sugerem que estratégias didáticas - que valorizam o contato dos alunos com diferentes tipos de textos científicos e expressam uma variedade de formas de argumentação e pontos de vista podem trazer certos beneficios. Entre as contribuições geradas por este contato ressaltam-se: acesso a uma maior diversidade, e até divergência de informações; desenvolvimento de habilidades de leitura e domínio de conceitos, de formas de argumentação e de elementos de terminologia científica. Assim, passar a conhecer uma variedade de tipos de textos 
científicos, desde reportagens de mídia até originais de cientistas, é condição para tornar-se um participante da cultura científica.

Ricon e Almeida (1991) analisam o papel e o uso de textos em sala de aula com vistas a atingir um objetivo que consideram como parte do ensino da ciência: a formação do sujeito-leitor:

Bom leitor, o estudante continuará mais tarde, já fora da escola, a buscar informações necessárias à vida de um cidadão, a checar notícias, a estudar, a se aprofundar num tema, ou simplesmente, a se dedicar à leitura pelo prazer de ler (RICON; ALMEIDA, 1991, p.9).

Em um outro artigo, Almeida e Ricon (1993) - ao questionarem se não seria papel da escola propiciar condições para aumentar o número de leitores interessados em idéias físicas e filosóficas - vêem os textos de divulgação científica e também os literários como uma possibilidade de acesso a ocorrências e controvérsias da ciência e da tecnologia; um meio para obter informações sobre inovações científico-tecnológicas, de desenvolver no estudante o gosto e o interesse pela leitura e pela ciência (no caso dos autores pela física) e, conseqüentemente, sua compreensão, contribuindo para a formação de hábitos e atitudes que permanecerão após o término das atividades estudantis.

Diante destas considerações, percebemos a importância de desenvolver no contexto escolar o interesse dos estudantes pela leitura como passo importante para a formação do leitor. Nesta perspectiva, este trabalho se propõe a refletir sobre o funcionamento da leitura de divulgação científica. Acreditamos que a leitura em ambientes de ensino precisa estar associada a outras possiveis formas de leitura no dia-a-dia dos cidadãos. Assim, concordamos com Gama (2005) quando afirma que, além de considerar o 
contato dos estudantes com a ciência não restrito ao espaço escolar, a escola e a universidade necessitam aceitar a premissa que os estudantes são produtores de sentidos, dentro e fora das salas de aula, e que a circulação desses sentidos é simultânea.

A preocupação com o potencial educacional de materiais sobre ciência publicados em jornais e revistas não é recente. Em 1964, um artigo publicado por Reis na revista Ciência e Cultura tratava do assunto (SILVA; KAWAMURA, 2001). Desde então, estudos têm demonstrado o interesse da comunidade de pesquisadores em educação em ciências no funcionamento de textos de divulgação científica no ambiente escolar a partir de uma variedade de perspectivas e pontos de vista. Tal preocupação encontra respaldo em recomendações curriculares recentes que encorajam o uso de uma diversidade de textos na sala de aula de ciências e enfatizam os benefícios advindos de sua leitura para a aquisição de vocabulário e entendimento conceitual:

\begin{abstract}
Além do livro didático, outras fontes oferecem textos informativos: enciclopédias, livros para-didáticos, artigos de jornais e revistas, folhetos de campanhas de saúde, de museus, textos da mídia informatizada, etc. É importante que o aluno possa ter acesso a uma diversidade de textos informativos, pois cada um deles tem estrutura e finalidades próprias. Trazem informações diferentes, e muitas vezes divergentes, sobre um mesmo assunto, além de requererem domínio de diferentes habilidades e conceitos para sua leitura (BRASIL, 1997, p.124).
\end{abstract}

Segundo Martins, Cassab e Rocha (2001, p.1-2): “o discurso científico engloba uma série de formações discursivas (o ensino de ciências na escola, a divulgação nos meios de comunicação, a disseminação de resultados de pesquisa na comunidade de pares), cada uma delas relacionadas a um conjunto particular de textos com estruturas genéricas distintas (livros 
didáticos, reportagens, artigos científicos)". Deste modo, o uso didático desses textos representa possibilidades variadas de experiências de aprendizagem para os alunos. Porém, esses autores consideram que essa apropriação didática não se dá de forma automática, pois é preciso: "um entendimento do seu funcionamento em cada contexto, das suas condições de produção e de seus efeitos sobre suas audiências, da natureza das reelaborações discursivas envolvidas nas recontextualizações dos mesmos, em particular da natureza das adaptações de textos científicos para sua utilização em contextos educacionais" (MARTINS; CASSAB; ROCHA, 2001, p.2). Por esta razão, faz-se necessária uma leitura crítica de tais textos pelo professor, por se tratarem de materiais que não foram concebidos originalmente com objetivos didáticos.

Além do respaldo encontrado em documentos curriculares oficiais, Terrazzan e Gabana (2003) lembram, ainda, que o relatório Habilidades de Leitura para o Mundo de Amanhã - publicado em conjunto pela OCDE (Organização para a Cooperação e o Desenvolvimento Econômico) e pela UNESCO (Organização das Nações Unidas para a Educação, a Ciência e a Cultura) - indicou que os estudantes brasileiros têm tido sérias dificuldades em usar a leitura como ferramenta para avançar e estender seus conhecimentos e habilidades em outras áreas. Portanto, as diferentes disciplinas escolares podem e devem contribuir para o desenvolvimento de atividades que lhes possibilite aumento gradativo na capacidade de compreensão dos materiais lidos, também, no gosto pela leitura. Logo, o estabelecimento nos alunos do hábito da leitura - fundamental para que 
possam participar plenamente do desenvolvimento de qualquer disciplina escolar - não é tarefa exclusiva dos professores da área de linguagem.

Para que isso ocorra, é de fundamental importância que percebam o potencial didático de outros textos que estejam mais próximos da leitura espontânea de seus alunos do que os textos dos livros didáticos. Seria desejável também que essas leituras fossem organizadas em atividades didáticas que permitissem e estimulassem maior grau de discussão e participação dos alunos nas próprias aulas.

No caso de aulas da área de ciências naturais, em particular de aulas de química, os textos de divulgação científica situam-se em posição privilegiada em relação aos diversos textos possiveis para uso didático, pois esses textos provavelmente serão lidos pelas pessoas que desejam se informar sobre assuntos científicos. Em que pese o fato de a população brasileira como um todo ter pouco hábito de leitura, aliado ao fato de ter graves limitações culturais e financeiras para aquisição de jornais e revistas, ainda assim o "consumo" de revistas de divulgação científica é relativamente alto entre jovens e adolescentes, sobretudo das classes com maior poder aquisitivo (TERRAZZAN; GABANA, 2003).

Desta forma, com base nas idéias aqui apresentadas, pretendemos neste trabalho investigar como funciona a leitura do livro de divulgação cientifica "Tio Tungstênio: memórias de uma infância quimica", de Oliver Sacks (2002), em uma classe do ensino superior de química, apoiadas na linha francesa da Análise do Discurso, em especial nos trabalhos de Eni Orlandi. Tendo em vista a natureza do presente trabalho, apresentaremos a seguir o entendimento de alguns autores sobre o significado da divulgação 
científica e um levantamento bibliográfico sobre textos de divulgação científica no ensino de ciências. Apresentaremos também uma síntese sobre o livro de divulgação científica anteriormente mencionado.

\subsection{Divulgação Científica}

Como primeiro passo para discutirmos a divulgação científica, procuramos verificar como o termo é definido. Não no sentido de aí encontrar o seu real e preciso significado, pois sabemos o quanto é fugidia e abstrata esta idéia, pois as palavras em um texto, segundo Orlandi (2000), possuem diferentes modos possiveis de leitura, em função de seus diferentes contextos históricos e de suas diferentes condições de produção:

s.f. ato, processo ou efeito de tornar pública alguma coisa; difusão, propagação, vulgarização. ETIM lat. divulgatìo,ónis 'ação de espalhar, publicar, divulgar'; ver vulg(i/o)-; f.hist. 1614 divulgaçan. SIN/VAR difusão, disseminação, generalização, preconício, propagação, propaganda, propalação, publicação, publicidade, reclamo, voga, vulgarização (HOUAISS, 2001).

Para Reis ${ }^{1}$ (2002, apud GERMANO; KULESZA, 2007), mais do que contar ao público os encantos e aspectos interessantes e revolucionários da ciência, a divulgação científica é a veiculação em termos simples da ciência como processo, dos princípios nela estabelecidos, das metodologias que emprega; revelando, sobretudo, a intensidade dos problemas sociais implícitos nessa atividade.

\footnotetext{
${ }^{1}$ REIS, J. Ponto de vista: José Reis (entrevista). In: MASSARANI, L.; MOREIRA, I.C.; BRITO, F. (Orgs.) Ciência e público: caminhos da divulgação científica no Brasil. Rio de Janeiro: Casas da Ciência, UFRJ, 2002.
} 
Ainda que a ciência tenha nítida influência no cotidiano humano, transformando-o, a distância entre o mundo científico e o homem comum tem sido cada vez maior. A divulgação científica aparece como atividade de caráter informativo e formativo, como instância importante de educação científica informal, com o intuito de diminuir o abismo entre os dois mundos (ADINOLFI, 2005). De acordo com Fourez (1995):

Em uma sociedade fortemente baseada na ciência e na tecnologia, a vulgarização científica tem implicações sóciopoliticas bem importantes. Se o conjunto da população não compreende nada de ciência, ou se permanece muda de admiração diante das maravilhas que podem realizar os cientistas, ela será pouco capaz de participar dos debates relativos às decisões que lhes dizem respeito. Se, pelo contrário, a vulgarização científica der às pessoas conhecimentos suficientemente práticos para que elas possam ponderar sobre as decisões com melhor conhecimento de causa, ou pelo menos saber em que especialista elas podem confiar, essa vulgarização é uma transmissão de poder (FOUREZ, 1995, p.43).

Na perspectiva de Authier-Revuz (1998), a reformulação do discurso de especialistas em ciência em um novo discurso para leigos é a principal característica do discurso da divulgação científica:

A divulgação científica é classicamente considerada como uma atividade de disseminação, em direção ao exterior, de conhecimentos científicos já produzidos e em circulação no interior de uma comunidade mais restrita; essa disseminação é feita fora da instituição escolar-universitária e não visa à formação de especialistas, isto é, não tem por objetivo estender a comunidade de origem (AUTHIER-REVUZ, 1998, p. 107).

Segundo a autora, na atividade de divulgação científica há uma reformulação do discurso científico. Esse processo origina o que a autora denomina vulgarização, no qual os divulgadores, primeiro auditório do discurso científico, julgam e retransmitem o discurso científico original a partir de uma série de critérios próprios:

Transmissão de um discurso existente em função de um novo receptor, a divulgação científica dá-se então, imediatamente, como uma prática de reformulação de um discurso-fonte em um discurso 
segundo. Por isso, a divulgação científica inscreve-se em um conjunto que compreende tradução, resumo, resenha e, também, textos pedagógicos adaptados a este ou àquele nível, análises políticas reformuladas 'na direção de' tal ou tal grupo social, mensagens publicitárias reescritas em função do 'alvo' visado etc. (AUTHIER-REVUZ, 1998, p. 108).

Para Orlandi (2001), o discurso da divulgação científica parte de um texto que é da ordem do discurso científico e, pela textualização jornalística organiza os sentidos de modo a manter um efeito-ciência, ou seja, encena na ordem do discurso jornalístico, através de uma certa organização textual, a ordem do discurso científico. De acordo com a autora (2001, p.151), o discurso da divulgação científica "é uma articulação específica com efeitos particulares, que se produzem pelo seu modo de injunção a seu modo de circulação, estipulando trajetos para a convivência social com a ciência”.

Segundo Maingueneau (1997), o discurso da divulgação científica comporta um grupo de textos que estão submetidos a coerções comuns que são determinantes de sua organização e conteúdo. Deste modo, a divulgação científica pode ser ainda compreendida como um gênero do discurso específico. Esta consideração baseia-se no fato de que a divulgação científica consiste no resultado de uma atividade discursiva que se desenvolve em condições de produção inteiramente diferentes daquelas em que o conhecimento científico é produzido pelos cientistas.

O discurso da divulgação científica pode ser caracterizado com base nos três elementos essenciais de qualquer gênero do discurso: o tema, o estilo e a composição (BAKHTIN, 2003). Com relação ao tema, o discurso da divulgação científica veicula conteúdos próprios à temática científica englobando, de forma mais ampla, temas sobre "ciência e tecnologia" 
(NASCIMENTO, 2005). No que diz respeito ao estilo e por ser dirigido a um destinatário leigo,

o discurso da divulgação científica deve dispensar a linguagem esotérica exigida pelo discurso científico preparado por e para especialistas e abrir-se para o emprego de analogias, aproximações, comparações. Simplificações - recursos que contribuem para corporificar um estilo que vai se constituir como marca da vulgarização discursiva (ZAMBONI, 2001, p.89).

No aspecto composicional, de acordo com Nascimento (2005, p.8), as formas de estruturação do discurso da divulgação científica põem em funcionamento procedimentos discursivos diversos nos quais se incluem, entre outros, "a recuperação de conhecimentos tácitos, a segmentação de informações, fórmulas de envolvimento, a presença de procedimentos explicativos, busca de credibilidade e a interlocução direta com o locutor".

Faz-se necessário ainda apresentar as importantes considerações de Silva (2006) a respeito da multiplicidade de textualizações do conhecimento científico. Para o autor, o termo divulgação científica, longe de designar um tipo específico de texto, está relacionado à forma como o conhecimento científico é produzido, como ele é formulado e como ele circula em uma sociedade como a nossa:

\begin{abstract}
A aparente obviedade da expressão divulgação científica faz-nos esquecer sua associação a todo um conjunto de representações e valores sobre a própria ciência, os textos que lhe são associados e o imaginário que os diferencia em termos de legitimação com relação ao conhecimento que veiculam os lugares por onde este e não aquele texto pode/deve circular (SILVA, 2006, p. 53).
\end{abstract}

O autor também explica que o fato de a esfera científica e outras esferas da sociedade jamais poderem ser totalmente independentes, faz com que as interlocuções envolvidas em sua produção não se restrinjam exclusivamente ao campo dos especialistas: 
A questão do que é 'interno' ou 'externo' à atividade científica é uma questão complexa se considerarmos que a ciência se produz na sociedade e que sua produção é algo extremamente complexo cujos atores envolvidos, direta ou indiretamente, jamais são exclusivamente os cientistas (SILVA, 2006, p. 56).

O que é importante deixar claro é o fato de os textos constituírem sentidos e simultaneamente sujeitos, posições de leitura e interlocuções. Desta forma, concordamos com Gama (2005) ao considerarmos que o discurso da divulgação científica não é simplesmente uma reformulação do discurso científico, como se o divulgador da ciência fosse um mero tradutor. O divulgador da ciência constrói um novo discurso e este apresenta características inerentes às suas condições de produção.

\subsection{Textos de divulgação científica no ensino de ciências}

Considerando que a pesquisa realizada envolveu a aplicação de uma proposta que tem o texto de divulgação científica como foco, realizamos um levantamento bibliográfico tomando por base os trabalhos apresentados nos Encontros Nacionais de Pesquisa em Educação em Ciências (ENPECs), no período de 1997 a 2007, os Livros de Resumo dos Encontros Nacionais de Ensino de Química (ENEQs), Encontros de Debates sobre o Ensino de Química (EDEQs) e Reuniões Anuais da Sociedade Brasileira de Quimica (RASBQs), seção Ensino de Química, no período de 1999 a 2007.

Buscamos, também, trabalhos sobre o tema em questão em revistas especializadas da área de educação em ciências, nos quadros nacional e internacional. Em se tratando de artigos no quadro nacional, realizamos uma busca na seção Educação da revista Química Nova (período de 1978 a 
julho de 2008) e na revista Quimica Nova na Escola (período de 1995 a maio de 2008), no entanto, não localizamos trabalhos publicados sobre o assunto em pauta nessas revistas. No âmbito internacional, verificamos a ocorrência do tema em foco através da realização de um levantamento bibliográfico abrangendo os artigos publicados no período de 1988 a julho de 2008 na revista Journal of Chemical Education (JCE), direcionada ao ensino superior de química e de ampla penetração internacional.

O levantamento foi realizado com o intuito de verificar as características dos trabalhos, publicados em congressos e revistas especializadas na área de educação em ciências, que dizem respeito à utilização de textos de divulgação científica no ensino de ciências.

Localizamos 62 trabalhos publicados nos eventos e periódicos pesquisados (APÊNDICE A). As constatações alcançadas a partir da leitura dos trabalhos foram úteis para o nosso entendimento sobre as potencialidades do uso de textos de divulgação científica no ensino de ciências e evidenciaram que as abordagens presentes na literatura são bastante variadas no que diz respeito às atividades propostas e às motivações que originaram os estudos.

Dentre os trabalhos localizados nos eventos e revistas citados anteriormente, destacam-se aqueles que tratam da seleção, caracterização, análise e/ou reelaboração de reportagens de revistas e jornais e de livros com viés de divulgação científica para fins escolares. Em quantidade menor são encontrados trabalhos que trazem experiências em salas de aula de ciências com textos de divulgação científica; assim como trabalhos que relacionam a formação de professores e o uso desses textos em contextos 
escolares e pesquisam a opinião dos mesmos com relação a esse uso. Por último, em menor número ainda que os anteriores, os trabalhos que trazem conceituações sobre divulgação científica e termos afins e apresentam reflexões sobre essa prática em ambientes escolares e os trabalhos que apresentam o estado da arte das pesquisas relacionadas à divulgação científica.

Cabe salientar que, embora a maioria dos trabalhos trate apenas de um dos tipos de abordagens acima citadas, alguns deles apresentam mais de um tipo. A seguir serão discutidos os trabalhos localizados.

1.2.1 Trabalhos que tratam da seleção, caracterização, análise e/ou reelaboração de reportagens de revistas e jornais e de livros com viés de divulgação científica para fins escolares

A partir da leitura dos trabalhos localizados percebemos que um dos maiores desafios da divulgação científica reside na dificil tarefa de transposição dos conhecimentos científicos para um público reconhecidamente leigo em ciência. Segundo Terrazzan e Gabana (2003), esses textos usam uma linguagem direta, abordam o assunto de forma simples e não possuem uma preocupação explícita em ensinar conceitos científicos. Por este motivo, algumas vezes, apresentam informações distorcidas ou de forma pouco rigorosa, o que pode contribuir para que os leitores construam concepções equivocadas sobre os conhecimentos científicos abordados. 
Assim, embora isto não invalide o uso de textos de divulgação científica - os próprios livros didáticos apresentam erros conceituais - é importante que o professor que se decidir por usá-los se responsabilize em relacionar as informações existentes no texto com os conhecimentos prévios dos alunos, de maneira que estes tenham maiores chances de atribuir significados adequados a estas informações.

Desta forma, pesquisas que orientem os professores na seleção do material que será levado à sala de aula são de extrema importância para que sejam bem sucedidas atividades com uso de textos de divulgação científica.

Verificamos que os trabalhos encontrados nesta temática exploravam diferentes aspectos, seja por meio da seleção de artigos de revistas e jornais relacionados a uma área específica do conhecimento (SALÉM; KAWAMURA, 1999; PEREIRA; PINTO NETO, 2003; AMORIM; MASSARANI, 2005; RIBEIRO; KAWAMURA, 2005; UCHÔA et al., 2005; BINSFELD; ZANON, 2007), seja pela investigação sobre reportagens que abordam um tema em questão (GOLDBACH; EL-HANI; MARTINS, 2005; GOMES; DA POIAN; GOLDBACH, 2007; KEMPER; ZIMMERMANN; GASTAL, 2007; LEGEY; COUTINHO, 2007).

Pesquisas que trazem a análise das potencialidades didáticas de artigos publicados em revistas de divulgação científica também foram encontradas (FERREIRA, 2003; MIRANDA, 2005), assim como críticas a notícias científicas veiculadas de maneira equivocada pela mídia jornalística (PEREZ; CALUZI, 2003). Além disso, algumas pesquisas tratam da análise das características lingüísticas de artigos de divulgação científica, como a reelaboração discursiva de textos desta natureza para textos didáticos 
(MARTINS; CASSAB; ROCHA, 2001; AIRES et al., 2003) e de textos científicos para textos de divulgação científica (GOUVÊA; BARROS, 2001), o estudo sobre a presença de analogias nesses textos (SILVA; TERRAZZAN, 2003; ZAMBON; TERRAZZAN, 2007), identificação de componentes argumentativos (QUEIROZ; SÁ, 2006), análise dos elementos de construção de sentidos (BROTERO; MARCONDES, 2005) e características presentes em diferentes discursos de divulgação cientifica (COSTA; CORREA; NASCIMENTO, 2003).

Trabalhos que tratam da análise de livros com viés de divulgação científica para fins escolares também foram encontrados. Ferrari, Angotti e Tragtenberg (2005) defenderam a utilização de publicações destinadas à divulgação científica como material de apoio na compreensão de conceitos científicos contemporâneos na formação inicial e continuada de professores. A validade desta proposta foi ilustrada através da reunião de diversas citações de vários livros destinados à divulgação científica, os quais apresentavam diferentes abordagens sobre um mesmo conceito. Os autores consideram que a publicação destinada à divulgação científica apresenta uma linguagem especial porque está situada entre a linguagem científica e a do público leigo. Deste modo, concluíram que foi possivel observar a contribuição dada por essas publicações, que revelam concepções implícitas sobre os modos de produção científica e ultrapassam a mera discussão do conceito específico.

Strack, Loguercio e Del Pino (2005, 2006a) investigaram livros de divulgação científica, potencialmente utilizáveis em aulas de química, e classificaram-nos em Metafórico/Fantástico (segundo a predominância das 
metáforas e/ou histórias fantásticas) e Histórico/Biográfico (de acordo com a narrativa que apresenta o perfil histórico do conhecimento e/ou do cientista). Esses autores verificaram ser possivel tomar conhecimento, através dos livros na forma mais literária, dos conceitos que se procura transmitir ao público em geral, da mesma forma que, através das biografias e dos romances históricos, tomar conhecimento do contexto cultural de uma época e da construção dos conhecimentos científicos. Deste modo, acreditam que a inserção da literatura de divulgação científica na sala de aula pode funcionar como instrumento de ressignificação da ciência e dos saberes que com ela se constroem. Os mesmos autores, em outro trabalho (2006b), realizaram um levantamento das principais contribuições conceituais que o livro autobiográfico “Tio Tungstênio: memórias de uma infância química” poderia trazer para aulas de química e propuseram o uso da literatura de divulgação científica como forma de contribuir para o ensino de química.

Ferrari, Angotti e Cruz (2005), por sua vez lançaram mão de alguns critérios de conceituação da literatura de divulgação científica para analisar o livro "O Grande, o Pequeno e a Mente Humana", de Roger Penrose (1998), e apontar características que o identificam como material de divulgação cientifica. Com este trabalho, os autores objetivaram incentivar o uso de material de divulgação científica no contexto da educação formal e esclarecer algumas peculiaridades desta obra em particular, com elementos de análise que auxiliassem os professores interessados em utilizá-la como material de apoio didático. Cabral (2003), por sua vez, apresenta uma discussão a respeito das representações de ciência e tecnologia no livro de divulgação científica “Clonagem: fatos e mitos”, de Lygia Vieira Pereira (2002). 
As conclusões apresentadas nesses trabalhos evidenciam o potencial didático do texto de divulgação científica como apoio ao ensino formal. Percebemos que esses pesquisadores partilham da mesma opinião quando concluem que os textos de divulgação científica podem contribuir para a construção de um conhecimento abrangente e contextualizado em sala de aula; porém, salientam que usar esses textos não se limita à sua inserção em situações usuais ou tradicionais de ensino, uma vez que requerem planejamento e reestruturação dessas práticas.

1.2.2 Trabalhos que apresentam experiências no ensino de ciências com textos de divulgação científica

Quanto às possibilidades do uso de textos de divulgação científica no contexto escolar, verificamos, no trabalho de Almeida e Ricon (1993), uma visão otimista a esse respeito. O otimismo está associado a seus efeitos motivacionais, apontando tais textos como possibilitadores de maior envolvimento, interesse e gosto. De acordo com os autores, os textos de divulgação científica podem aproximar os alunos da ciência dentro e fora da escola.

Terrazzan e Gabana (2003) reforçam o papel importante da divulgação cientifica no ambiente educacional quando afirmam que a mesma tem exercido papel fundamental na educação, informação e debate acerca do desenvolvimento científico e seus desdobramentos éticos:

O uso de textos de divulgação científica em sala de aula possibilita e auxilia a discussão de fatos/acontecimentos que estão vinculados com o cotidiano dos alunos. $\mathrm{E}$ isto contribui principalmente no sentido de apontar para a viabilidade de se atingir possiveis 
mudanças curriculares que levem em conta a presença forte e permanente da Ciência e Tecnologia no mundo contemporâneo (TERRAZZAN; GABANA, 2003, p. 8).

Quanto aos trabalhos pesquisados que mostravam experiências com textos de divulgação científica no ensino de ciências, verificamos que, de um modo geral, apresentam como principais objetivos: auxiliar no processo de ensino e aprendizagem de conteúdos específicos das disciplinas, aperfeiçoar as habilidades de comunicação oral e/ou escrita dos estudantes e favorecer o seu entendimento sobre o processo de construção do conhecimento científico.

Almeida (1997), em seu trabalho apresentou conseqüências de questões formuladas em atividades envolvendo a leitura de textos de divulgação científica. Essas atividades foram propostas para alunos das disciplinas ciências e física e para professores do ensino fundamental e médio. A autora focalizou a linguagem verbal como mediadora de concepções e representações de alunos e professores e apontou a necessidade de superação de hábitos de leitura comuns no contexto escolar, de modo que as respostas para as questões formuladas não se restrinjam exclusivamente aos resultados da ciência.

Monteiro, Monteiro e Gaspar (2003) utilizaram a revista Superinteressante em aulas de física no ensino médio para analisar o emprego de textos de divulgação científica como elemento desencadeador de discussões acerca de assuntos científicos. Através da observação e análise dessas atividades, os autores buscaram algumas indicações para que esses textos fossem melhor aproveitados no sentido de otimizar o processo de ensino e aprendizagem. De acordo com os autores, trazer aos alunos textos 
que utilizem a linguagem próxima de contextos próprios da cultura científica pode oferecer significativa contribuição para a aprendizagem de conceitos cientificos, haja vista as múltiplas interações sociais que é possivel serem observadas durante essa atividade entre alunos e professor e entre os próprios alunos.

Chagas, Barbosa e Navega (2004) lançaram mão de fotos e reportagens jornalísticas como temas geradores de discussão sobre assuntos químicos, no sentido de por em prática recomendações curriculares de um aprendizado com vistas à cidadania.

Field's e Rastrelo (2004) trabalharam os conceitos Ligação Química e Forças Intermoleculares com o auxílio da revista eletrônica $Q M C W E B$ em uma disciplina de química ofertada em um curso de graduação em biologia. Como resultado os autores observaram um aumento da motivação por parte dos alunos e melhor entendimento de conceitos até então considerados de difícil compreensão.

Campos et al. (2005) relatam em seu trabalho a produção de um jornal por estudantes de ensino médio que contemplou assuntos químicos ligados aos interesses dos adolescentes, como química na higiene e beleza, nas tatuagens e piercings, na alimentação, entre outros.

Galagovsky et al. (2007) usaram textos de divulgação científica no ensino dos tópicos Combustão e Tabela Periódica para alunos matriculados, respectivamente, em um centro de Enseñanza para Adultos, Provincia de Buenos Aires, e em um curso superior de química, Estado de São Paulo. As autoras concluíram que a instauração em aulas de química de um contexto de leitura distinto daquele oferecido pelo livro didático pode melhorar a 
qualidade das interações em aula e favorecer um maior conhecimento sobre os alunos por parte do professor, o que possibilita o aprimoramento do processo de ensino-aprendizagem.

Menegat, Clement e Terrazzan (2007) descreveram uma estratégia didática com uso de textos de divulgação científica em aulas de física em uma perspectiva investigativa, partindo de situações-problema. Os autores tomaram como pressuposto que esses textos não podem ser apenas lidos em sala de aula, mas deve haver uma forma de trabalho que propicie, entre outros aspectos, a realização de questionamentos, a troca de idéias e a capacidade de análise textual.

Prestes e Silva (2007) analisaram a incorporação de artigos de divulgação científica publicados em jornais de circulação nacional sobre questões energéticas na sala de aula de física no ensino médio. O objetivo desses autores era subsidiar o uso dos artigos como recurso didático e fonte de aprendizagem, possibilitando discussões e atividades nas quais os alunos pudessem expor suas concepções e criticassem/debatessem outras concepções, reconstruindo seus conhecimentos sobre problemas energéticos.

Uma atividade baseada na utilização de fragmentos do livro autobiográfico "A Tabela Periódica", de autoria de Primo Levi (1994), foi realizada em um curso de graduação em química por Osório et al. (2005). Esses fragmentos foram lidos pelos alunos que, em seguida, redigiram um trabalho escrito baseado na análise do texto. A partir da análise da produção dos alunos, os autores concluíram que o uso do texto permitiu uma abordagem integradora de conteúdos estudados em diferentes disciplinas do curso. Osório, Tiedemann e Porto (2007) utilizaram textos selecionados do 
mesmo livro como apoio a duas disciplinas do ensino superior de química. Na primeira disciplina, Química dos Elementos, os alunos deveriam fazer a leitura do texto e responder a três perguntas. O objetivo da atividade, segundo os autores, era auxiliar os estudantes a recordarem conhecimentos sobre a Tabela Periódica. O segundo uso do texto ocorreu na disciplina de Química Integrada, que envolve aspectos da Química Geral e Inorgânica. Os alunos receberam uma cópia do texto e foram instruídos a analisar cada fato químico ali mencionado, tentando explicá-los à luz dos conhecimentos químicos aprendidos.

Em pesquisa por nós levada a cabo, observamos a produção de sentidos proporcionada pela leitura do livro "Tio Tungstênio: memórias de uma infância química" no contexto de uma disciplina do ensino superior de química. Através de atividades de leitura, percebemos a produção de alguns sentidos que não costumam estar presentes em aulas de disciplinas de graduação em química que sugerem uma possível postura crítica por parte dos alunos frente a discussões apresentadas no texto, o que é desejável para a sua formação (ABREU; MASSI; QUEIROZ, 2007).

Comeford (1997) relata ter obtido resultados satisfatórios ao adotar a leitura de textos de divulgação científica em aulas de Físico-Química, atrelada à solicitação de tarefas escritas baseadas nessa leitura, como recurso capaz de diversificar a abordagem normalmente usada na disciplina. No tópico Química Quântica, o livro “In Search of Scrödinger's Cat: Quantum Physics and Reality", de John Gribbin (1984), foi usado com este propósito.

Observamos também a utilização de textos de divulgação científica como apoio a atividades didáticas realizadas em disciplinas de caráter 
prático, como no trabalho de Samet e Higgins (2005), que alia a leitura do livro “Napoleon's Buttons: How 17 Molecules Changed History" - de autoria de Le Couteur e Burreson (2003) - às aulas teóricas e práticas de Química Orgânica. Segundo as autoras, o livro é repleto de exemplos de moléculas que afetaram a história da humanidade, podendo auxiliar os estudantes na compreensão da influência da estrutura molecular nas propriedades de várias substâncias químicas. Em cada uma das aulas teóricas, um capítulo do livro era selecionado para leitura. Nos experimentos realizados no laboratório os estudantes tiveram a oportunidade de observar propriedades de certas substâncias e comparar suas observações com as informações contidas no texto.

A utilização de textos de divulgação científica com o intuito de promover o conhecimento sobre as condições de produção da ciência, a história da química e a vida dos cientistas é observada nos trabalhos reportados por Carroll e Seemam (2001) e Dybowski (2001). No trabalho de Carroll e Seemam (2001), alunos da disciplina de Química Orgânica Avançada realizaram a leitura da autobiografia "From Cologne to Chapel Hill", de autoria de Ernest L. Eliel (1990), elaboraram um artigo referente a tópicos específicos do livro e realizaram posteriores discussões em equipes. No trabalho de Dybowski (2001), alunos de Físico-Química fizeram a leitura de partes dos livros "The World of Physical Chemistry", de autoria de Keith J. Laidler (1993), e "Physical Chemistry from Ostwald to Pauling: The Making of A Science in América", de autoria de John W. Servos (1990). Segundo a autora, estes livros apresentam o mesmo registro histórico sob perspectivas diferentes, uma vez que um dos livros é escrito por um químico e o outro por 
um historiador. Através de discussões posteriores à leitura, os estudantes examinaram um mesmo evento sob diferentes pontos de vista e expuseram suas opiniões.

Alguns trabalhos apresentam iniciativas de instituições de ensino em apresentar a química de forma mais abrangente e contextualizada aos estudantes e à população, através da produção de materiais de divulgação de assuntos químicos. Ribeiro et al. (2006) relatam a criação de um jornal em um centro federal de educação tecnológica que trata a química de forma lúdica, multidisciplinar e relacionada ao cotidiano dos alunos. Soares e Oliveira (2006) apresentam as tentativas do instituto de química de uma universidade paulista em divulgar a sua produção científica e acadêmica, através da criação de um portal de notícias e da publicação de notícias em veículos de informação da cidade, além da editoração e distribuição de um jornal, entregue bimestralmente em escolas de ensino médio com o objetivo de despertar o interesse dos alunos pela química. Iniciativa semelhante é realizada pelo curso de química de uma universidade paranaense, que apresenta a divulgação da ciência e tecnologia em textos escritos em um jornal de circulação regional (LINDINO; CUNHA, 2004).

Tendo em vista o conteúdo e o teor dos trabalhos descritos, percebemos que os estudiosos do assunto acreditam que sua utilização pode enriquecer o ensino, trazer novas questões, abrir a visão de mundo do aluno e do professor, favorecer novas metodologias de ensino, localizar o conteúdo ensinado em contextos mais abrangentes, motivar e aprofundar determinados assuntos. 
1.2.3 Trabalhos que relacionam a formação de professores e o uso de textos de divulgação científica em contextos escolares e investigam a sua opinião com relação ao uso de textos desta natureza

Além de pesquisas realizadas com o objetivo de investigar o funcionamento de textos de divulgação científica em sala de aula, outra linha de investigação trata de estabelecer relações entre a formação de professores e a utilização de tais textos, visando estabelecer diretrizes que os guiem em sala de aula no uso desse material. Em alguns trabalhos nessa mesma linha, observamos também a realização de entrevistas com professores visando conhecer principalmente suas opiniões em relação a essa prática e que tipo de material de divulgação cientifica eles costumam levar para a sala de aula.

Martins et al. (2001) investigaram a prática de alguns professores de ciências que fazem uso de textos de divulgação científica em suas salas de aula e exploraram a idéia de que esses textos podem complementar materiais tradicionais, como o livro didático, permitindo a discussão do caráter dinâmico do conhecimento científico, das informações e das imagens de ciência que circulam em nossa sociedade. Uma pesquisa de mesma natureza foi levada a efeito por Rocha e Martins (2001), que fizeram um estudo envolvendo entrevistas individuais com professores de ciências do ensino fundamental, tanto da rede pública como da rede particular do Rio de Janeiro. Nessas entrevistas discutiram como os professores selecionavam, adaptavam e utilizavam textos de divulgação científica na sala de aula. 
Brotero e Marcondes (2006) entrevistaram professores de química do ensino médio, de modo a compreender suas práticas e a possivel inserção de textos de divulgação científica em sala de aula. O trabalho reportado por Strack, Loguercio e Del Pino (2007) refere-se às percepções de professores que lecionam em um curso de licenciatura em química - a respeito do uso da literatura de divulgação científica em sala de aula. Desta forma, os autores buscaram verificar o que pensam os professores sobre os aspectos das narrativas envolvidas, os espaços e tempos ideais para diferentes niveis de ensino e o uso ou não desse tipo de literatura no ensino superior. Nascimento e Souza (2007) investigaram os discursos de licenciandos de um curso de graduação em ciências biológicas no que tange às suas concepções de leitura e a seus modos de leitura de textos de divulgação científica utilizados em suas experiências na prática de ensino.

Nos trabalhos de Chaves, Mezzomo e Terrazzan (2001a, 2001b, 2001c), Gabana, Lunardi e Terrazzan (2003) e Terrazzan e Gabana (2003) encontramos investigações sobre as possibilidades de introdução de temáticas específicas para o ensino de física, através da elaboração e implementação de estratégias didáticas utilizando textos de divulgação científica. As estratégias foram aplicadas por vários professores em diferentes turmas de ensino médio. Esses autores relataram a evidência de que práticas e hábitos de leitura não são uma constante entre os professores e, desta forma, a utilização de textos diferenciados em sala de aula pode servir para questionar práticas tradicionais, levando a outra percepção e necessidade de estruturação de novas práticas. 
Chaves, Mezzomo e Terrazzan (2001a, 2001b, 2001c) enfatizam que, para trabalhar com esse tipo de material em sala de aula, é preciso que os professores - como responsáveis pela formação de sujeitos-leitores críticos incentivem a realização das leituras, bem como a compreensão e a discussão dos textos indicados. No trabalho reportado por esses autores e por Terrazzan e Gabana (2003) encontramos as seguintes considerações sobre o assunto:

i) É necessário que o professor se conscientize da importância de levar o texto de divulgação científica para a sala de aula através de estratégias bem pensadas e elaboradas;

ii) É preciso que o professor tenha consciência de que ele próprio precisa ler estas publicações ou reportagens e estar minimamente informado e preparado para o tratamento e discussão, de modo que possa assumir a postura de mediador entre as informações trazidas pelo texto e as informações trazidas pelos alunos;

iii) A utilização de textos de divulgação científica em sala de aula também pode deixar o professor inseguro em um primeiro momento. Segundo os autores, isso acontece porque a leitura desses textos proporciona diversidade de informações sobre assuntos variados, ao contrário dos livros didáticos que costumam apresentar os conteúdos de forma focada e compactada;

iv) Para fazer uso de qualquer outro recurso que não seja apenas exposição, o professor sempre deverá disponibilizar tempo suficiente para que a atividade didática seja desenvolvida de forma adequada. 
Neste sentido, é comum o professor se deparar com um dilema muito freqüente: cumprir o conteúdo programático a qualquer custo.

1.2.4 Trabalhos que trazem conceituações sobre divulgação científica e termos afins e apresentam reflexões a respeito dessa prática em ambientes escolares

Com base nos materiais lidos, verificamos que estudos que têm a divulgação científica como objeto não se concentram apenas na investigação de aspectos relacionados à utilização desses textos em aulas de ciências, mas também em reflexões teóricas acerca do contexto de sua produção, sua conceituação e sua adaptação em ambientes de ensino.

Marandino et al. (2003) procuraram definir e aprofundar os conceitos educação não formal e divulgação científica, a partir de levantamento teórico e da experiência de profissionais que atuam nessas áreas. Os autores constataram que os dados obtidos reforçaram a percepção da inexistência de uma definição comum desses termos tanto na bibliografia como entre os profissionais da área. Cunha e Giordan (2006) discutem as relações existentes entre a educação formal e a educação informal no sentido de estabelecer as interações possiveis entre estes dois contextos e tendo em vista analisá-los segundo a psicologia sócio-interacionista de Vygotski, com intenções em estudar a influência das mídias na consolidação de um conhecimento científico pretendido na escola.

Custódio e Ricardo (2003) apresentam em seu trabalho reflexões sobre o conceito de divulgação científica à luz das noções de indústria cultural e 
semicultura e enfatizam o desenvolvimento de senso crítico nos indivíduos como papel primordial da divulgação científica.

No trabalho reportado por Valério (2005), encontramos discussões sobre alguns dos principais desafios da prática de divulgação científica apoiadas na epistemologia de Gaston Bachelard. Apresentando a concepção bachelardiana de conhecimento científico, sua noção de obstáculos pedagógicos e suas ponderações sobre o problema da simplificação da ciência, o autor constrói um discurso sobre os limites e possibilidades dessa prática e seu papel na formação dos cidadãos. Segundo o autor, transformar em inteligivel a linguagem especializada da ciência configura um desafio que o divulgador precisa enfrentar. Ele enfatiza, ainda, que um modo mais usual de sobrepujar esse entrave seria promover uma simplificação da linguagem científica através do uso de metáforas, ilustrações e imagens. A dimensão problemática dessa questão é que esse ímpeto simplificador, muitas vezes, acaba por atingir também aquilo que se deseja divulgar e desvirtua o tema científico, prestando-se apenas para apresentar o resultado das pesquisas, como se a ciência sempre fornecesse conclusões e verdades. Desta forma, a divulgação científica promove uma espetacularização da ciência, incorrendo em um sensacionalismo que contribui apenas para despertar curiosidade no público, conferindo pouco ou nenhum significado à formação. Desta perspectiva de divulgação científica resulta não só o comprometimento do caráter informativo da divulgação científica, mas também a inviabilidade das intenções educativas que poderiam ser contempladas.

Diante dessas considerações, chamamos também atenção para o trabalho de Nascimento (2005) que reconhece duas origens para os possiveis 
problemas decorrentes da utilização dos referidos textos, as quais se encontram relacionadas às mediações que ocorrem: o processo de produção do texto de divulgação científica e a sua inserção na sala de aula. A primeira mediação é caracterizada pela remodelização do conhecimento científico, que é fundamental pois, neste processo, a linguagem utilizada nos textos de divulgação científica pode confundir, complicar e até mesmo veicular de forma errada os conceitos científicos neles apresentados. A segunda mediação, ocorrida já no âmbito do ensino formal, acontece no ato da leitura. Durante a interação entre leitor e texto, estabelecem-se diferentes sentidos, de modo que a compreensão dos conceitos e fenômenos científicos pode estar mais próxima ou mais distante do significado aceito e compartilhado por aqueles que o produziram. É nesse momento que a simplificação da linguagem científica poderá produzir diferentes sentidos e consolidar-se ou não como um obstáculo à aprendizagem do conceito cientificamente correto. A autora explica ainda que, nos dois casos em que ocorrem as mediações, existe a possibilidade de surgirem deslocamentos de sentido, ou seja, que diferentes compreensões sejam estabelecidas por diferentes alunos a partir do contato com um mesmo texto.

De acordo com Orlandi (1996a), os deslocamentos de sentidos são possiveis devido ao fato de o sentido não se encontrar inscrito no texto; portanto existe a possibilidade de diferentes compreensões por distintos sujeitos. Segundo a autora, isso ocorre porque como cada leitor possui diferentes histórias de leitura, ele pode tecer relações com textos lidos anteriormente e, assim, o sentido pode ser alargado ou restringido. 
Uma forma de reduzir os possiveis deslocamentos de sentido durante a leitura consiste em o professor fazer adaptações de acordo com os seus objetivos didático-pedagógicos e adotá-las no momento em que os textos são utilizados em sala de aula. Nesta etapa, os professores selecionam, complementam e destacam determinadas informações que lhes interessam, além de estabelecerem relações com conceitos e fenômenos anteriormente estudados (MARTINS; NASCIMENTO; ABREU, 2004).

1.2.5 Trabalhos que apresentam o estado da arte das pesquisas relacionadas à divulgação científica

Dentre os trabalhos investigados, temos aqueles que fazem uma análise das produções científicas sobre a temática em questão, como a pesquisa quantitativa de Nascimento e Souza (2005), que mapeiam os estudos sobre divulgação científica e ensino de ciências, através do levantamento de trabalhos sobre o tema em foco entre 1997 e 2005 em eventos de biologia, física e ciências. Já no trabalho de Puiati, Borowsky e Terrazzan (2007), encontramos um estudo analitico das produções das cinco primeiras edições dos ENPECs sobre o uso do texto de divulgação científica no ensino básico e como ele é abordado/recebido por professores e alunos. Os autores constataram que os professores recorrem às fontes de divulgação científica como suporte para suas atividades, porém sentem dificuldades em organizá-las e utilizá-las, assim como os alunos demonstram grande interesse e motivação pelos textos de divulgação científica. 
A análise realizada por Ianini et al. (2007), a partir de levantamento realizado sobre os referenciais teóricos nacionais na área de divulgação científica e educação não formal no ensino de ciências e matemática, revela a existência de um importante histórico de pesquisa na área, com publicações em periódicos de reconhecimento nacional e internacional e linhas de pesquisa estruturadas.

\subsection{Tio Tungstênio: memórias de uma infância química}

O livro escolhido para a aplicação da proposta de ensino trata da autobiografia de Oliver Sacks (2002), “Tio Tungstênio: memórias de uma infância química". Neste tópico faremos algumas considerações referentes a este livro com relação aos aspectos que o caracterizam como material de divulgação científica. No entanto, primeiramente, cabe dedicar algumas linhas a uma descrição da obra e dos capítulos selecionados para utilização em sala de aula: O jardim de Mendeleiev e Luz brilhante.

A obra mencionada remete às primeiras descobertas de um inquieto cientista nato, contendo fotos e ilustrações no início de cada um dos seus 25 capitulos, além de uma tabela periódica em página dupla, fotografias de familiares e índice remissivo.

Nascido em Londres em 1933, Oliver Sacks é um neurologista que reside em Nova York e, entre outros livros, publicou: "O homem que confundiu sua mulher com um chapéu", "Um antropólogo em Marte" e "Tempo de despertar" (este levado ao cinema). Em Tio Tungstênio, ele narra sua infância e adolescência em Londres com riqueza de detalhes, 
particularmente no período da Segunda Guerra Mundial. Oliver Sacks mostra uma história familiar marcada por um convivio muito íntimo com a ciência. Nascido em uma família judia de emigrantes da Europa Central, filho de pais médicos e convivendo com tios e primos que tinham ligações muito próximas com aplicações das mais recentes descobertas da física e da química, o autor teve uma infância e adolescência marcada pela curiosidade e pela investigação. Deste modo, cresceu entre experiências com metais, consultas médicas no ambiente caseiro e muita cultura química, inebriado por uma visão romântica da ciência.

Entre os familiares que direcionam o espírito investigativo de Sacks está Tio Dave, que fabricava lâmpadas de tungstênio - aí se encontra a razão do nome do livro - e instigava seu sobrinho a repetir experimentos químicos em um laboratório doméstico que ajudou a montar. Deste modo, o autor realizou experiências que poucos dos profissionais da química de hoje em dia tiveram a oportunidade de realizar e outras que são comuns nos laboratórios atuais de ensino. Mais que isto, sua mente investigativa fazia-o perseguir muitas das questões mais fundamentais da química, deslumbrando-se o tempo todo ao perceber os grandes feitos de cientistas como Davy, Boyle, Bohr, Rutherford, o casal Curie, Moseley, Cannizzaro, Faraday, Dalton, Priestley, Kirchhoff, Kelvin, Mendeleiev e outros.

$\mathrm{Na}$ literatura são feitas menções sobre o uso do referido livro como recurso didático. Nos trabalhos de Strack, Loguercio e Del Pino (2005, 2006a, 2006b), os autores definem o livro, entre outros, como potencialmente utilizável em aulas de química e destacam as seguintes noções teóricas nele 
presentes: Elementos Químicos, Propriedades dos Metais, Interações

Eletromagnéticas, Radioatividade e Reações Químicas.

Chassot (2005) recomenda com entusiasmo a leitura do livro, especialmente com relação aos aspectos históricos contidos no texto:

Aqueles que desejarem se iniciar na história da Ciência da primeira metade do século 20 encontram em Tio Tungstênio um excelente condutor para conhecerem detalhes de realizações como as de Niels Bohr ou as de Marie Curie ou ainda mais conhecer, entre outras, a história da eletricidade, da descoberta do Raio X ou ainda da genialidade de Mendeleiev no estabelecimento da Tabela Periódica (CHASSOT, 2005).

Devemos ressaltar ainda as menções em revistas da área de educação em química. Schwartz (2002), em resenha publicada no Journal of Chemical Education, considera o livro como uma exposição pública positiva e necessária à química e recomenda sua leitura a todos os químicos.

Faria (2003, p. 625), em carta destinada ao editor da revista Química Nova, relata que "sua forma leve de escrever faz do livro uma leitura fácil e agradável, embora repleta de conceitos fundamentais para o entendimento do mundo que nos cerca, em especial o da química". O autor fala ainda sobre a baixa ocorrência de erros conceituais no livro - problema muito freqüente na literatura de divulgação científica:

Poucos erros são encontrados, podendo ter sido originados quando da tradução como, por exemplo, na página 207, onde o H2S é chamado de híbrido de enxofre e, na página 118 , onde descreve a formação de $\mathrm{CO} 2$ pelo aquecimento de gesso com $\mathrm{HCl}$. Não há, porém, qualquer erro conceitual e o desenrolar histórico de muitos dos grandes acontecimentos científicos é muito enriquecedor, mesmo para aqueles com ampla cultura química (FARIA, 2003, p. 625).

Tio Tungstênio traz de volta o romantismo da química e das grandes descobertas. Romantismo que, segundo Sacks, foi definitivamente perdido 
quando explodiu a primeira bomba atômica sobre o Japão e que o levou a concluir:

\begin{abstract}
Até então, a química e a física haviam sido, para mim, uma fonte de puro deleite e fascínio, e eu não tinha plena consciência, talvez, de seus poderes negativos. A bomba atômica abalou-me como a todo mundo. A física atômica ou nuclear, pensamos, nunca mais poderia avançar com a mesma inocência e despreocupação da época de Rutherford e dos Curie (SACKS, 2002, p. 292).
\end{abstract}

De acordo com Faria (2003), a partir de então, e cada vez mais, sempre que ocorre um acidente ecológico, por exemplo, muito se fala contra a química e pouco se tem conseguido fazer para reduzir este estigma pejorativo já bastante arraigado na população. Deste modo, o autor acrescenta que o livro ajuda a sanar esta questão através de um relato de uma infância química prazerosa em meio a gases, metais e explosões, recomendando a obra como texto suplementar no ensino de química, em todos os níveis; ajuda ainda a formar cidadãos mais conscientes da importância das ciências para o desenvolvimento social e econômico.

\title{
1.3.1 Capitulo 16: O jardim de Mendeleiev
}

Neste capítulo, Oliver Sacks (2002) relata seu primeiro contato com a Classificação Periódica dos Elementos Químicos, em uma de suas muitas visitas ao Science Museum². Este relato não consiste somente na narração dos fatos, mas em uma descrição minuciosa de diversos aspectos inerentes à Tabela Periódica. Dentre estes aspectos podemos mencionar a descrição física - cores, formas - dos elementos químicos:

\footnotetext{
${ }^{2}$ Science Museum, Londres, Inglaterra. Disponivel em: < http://www.sciencemuseum.org.uk/>. Acesso em: 22 jun. 2008.
} 
Minha primeira visão foram os metais, dúzias deles em todas as formas possiveis: bastões, nacos, cubos, filamentos, folhas, discos, cristais. A maioria era cinzenta ou prateada, alguns tinham um leve toque azul ou rosa. Uns poucos tinham superficies com um pálido brilho amarelado, e por fim havia as cores vivas do cobre e do ouro (SACKS, 2002, p. 190).

É interessante notar a riqueza de detalhes e a maneira entusiasmada com que o autor descreve as características de alguns elementos, como podemos observar no trecho a seguir:

O césio, eu sabia, tinha um ponto de fusão baixíssimo, e aquele era um dia quente de verão. Mas eu não havia percebido plenamente, nos pedacinhos parcialmente oxidados que vira, que o césio puro era dourado - de início emitia apenas um lampejo, um clarão dourado, parecendo iridescente nos tons áureos; e então, olhado de um ângulo inferior, ele era de um dourado puro, fazia pensar em um mar de ouro ou mercúrio dourado (SACKS, 2002, p.191).

Outro aspecto importante a ser destacado é que, ao longo deste capítulo, o autor não faz apenas uma descrição dos elementos químicos, mas também uma explicação didática - embora não pareça intencional - sobre o surgimento da Tabela Periódica e os princípios químicos que edificaram a sua classificação. Podemos perceber esta preocupação do autor no seguinte exemplo:

Essas familias (que Mendeleiev chamou de 'grupos') compunham as verticais da tabela, com os álcalis e os metais alcalino-terrosos à esquerda, os halogênios e gases inertes à direita e todo o resto em quatro grupos intermediários... Devia haver algum princípio mais profundo em ação - e de fato havia. Estava impresso no topo da tabela, mas na impaciência de ver os elementos propriamente ditos, eu não prestara atenção. O princípio mais profundo, enxerguei então, era a valência (SACKS, 2002, p.191-192).

Em muitos momentos ao longo do capítulo percebemos a forma simples e prática de explicar certos conceitos químicos, como por exemplo, a afinidade química entre dois elementos:

Podiamos perceber, também em um relance, que os elementos das duas fronteiras do reino - os metais alcalinos e os halogênios, como o 
sódio e o cloro, por exemplo - mostravam a maior avidez um pelo outro e se combinavam com força explosiva, formando sais cristalinos com pontos de fusão elevados que se dissolviam formando eletrólitos... (SACKS, 2002, p.197).

Além de trazer uma associação conceitual aos fatos narrados, Sacks faz também com que o leitor se situe historicamente em todos os momentos do capítulo, não se restringe a atribuir os feitos aos seus descobridores, mas em deixar suas impressões pessoais sobre os mesmos:

Havia no museu uma fotografia de Mendeleiev ao lado da tabela periódica; ele parecia uma mistura de Fagin e Svengali, barbudo, de cabeleira densa e olhos penetrantes, hipnóticos. (...) Seu livro, sua vida, não me desapontaram. Ele foi um homem de interesses enciclopédicos. Foi amante da música e amigo próximo de Borodin (que também era químico). $\mathrm{E}$ foi autor do mais envolvente e vívido texto sobre química já publicado, Princípios de química (SACKS, 2002, p.198).

Sacks enfatiza, ainda, os obstáculos percorridos pelos cientistas envolvidos em sua narrativa, obstáculos esses que geralmente são ocultados pelo brilho de suas descobertas:

Como meus pais, Mendeleiev provinha de uma família enorme - era o mais novo de catorze filhos. Sua mãe com certeza reconheceu nele a inteligência precoce; quando o filho fez catorze anos, pressentindo que estaria perdido sem uma educação adequada, ela saiu da Sibéria e percorreu milhares de quilômetros a pé com ele, primeiro até a Universidade de Moscou (que não o aceitou por ser siberiano), e depois até São Petersburgo, onde lhe foi concedida uma bolsa de estudos para a carreira do magistério... (SACKS, 2002, p.191).

\subsubsection{Capitulo 24: Luz brilhante}

Neste capitulo, Oliver Sacks faz uma narrativa dos fatos históricos que envolveram a teoria atômica, descrevendo minuciosamente as experiências realizadas por cientistas como Prout, Moseley, Rutherford, Bohr; e assim como no capítulo anteriormente mencionado, observamos os traços de entusiasmo colocados pelo autor em diversos pontos do texto: 
Em 1913, um século depois de Prout, Harry Moseley, jovem e brilhante fisico que trabalhava com Rutherford, começou a investigar átomos com a recém-desenvolvida técnica da espectroscopia de raios $X$. Sua aparelhagem experimental era encantadora e pueril: um trenzinho onde cada vagão transportava um elemento diferente passava por um tubo de vácuo de noventa centímetros de comprimento, onde Moseley bombardeava cada elemento com raios catódicos, fazendo com que emitissem raios X característicos (SACKS, 2002, p.294).

Também é digna de nota a forma como o autor instiga o leitor a interessar-se pela narrativa e, junto com ele, a sentir-se curioso pelo que vai acontecer em seu decorrer e tentar desvendar os "mistérios" que cercam esta história, como podemos observar nos trechos a seguir:

Embora Moseley houvesse mostrado o número e a ordem reais dos elementos, outras questões fundamentais ainda permaneciam, questões que haviam perturbado Mendeleiev e os cientistas de sua época, questões que perturbaram tio Abe na juventude e que agora me perturbavam, pois os encantos da química, da espectroscopia e das brincadeiras com a radioatividade deram lugar a um furioso por quê? Por que, antes de mais nada, existiam elementos, e por que tinham suas propriedades especificas? O que tornava os metais alcalinos e os halogênios, de modo opostos, tão violentamente ativos? O que explicava a semelhança dos elementos de terras-raras e as belas cores e propriedades magnéticas de seus sais?... (SACKS, 2002, p.295-296).

Devemos frisar também que todos os passos da narrativa são acompanhados de definições e explicações dos conceitos químicos envolvidos e, uma vez mais, enfatizamos a maneira agradável que o autor utiliza nas explicações dos conceitos, tornando-os de mais fácil entendimento para o leitor:

E aí, com os elétrons, o modelo de Rutherford soçobrava. Segundo a física clássica, maxwelliana, um átomo desse tipo, assemelhado a um sistema solar, não poderia funcionar, pois os elétrons rodopiando ao redor do núcleo mais de um trilhão de vezes por segundo criariam radiação em forma de luz visível, e um átomo assim emitiria uma centelha de luz momentânea e então implodiria quando seus elétrons, tendo perdido energia, seriam impelidos para o núcleo. Mas a realidade era que os elementos e seus átomos duravam bilhões de anos... Então, como um átomo podia ser estável, resistir ao que parecia ser um destino quase instantâneo? (SACKS, 2002, p.296). 
Outro aspecto relevante a ser ressaltado no texto são os importantes fatos históricos, detalhadamente contados pelo autor, que retratam acontecimentos que, via de regra, não são mencionados em livros didáticos:

Em 1914, os cientistas da Grã-Bretanha, França, Alemanha e Áustria foram todos envolvidos, de vários modos, na Primeira Guerra Mundial. A química e a física puras foram, em grande medida, suspensas no periodo, e a ciência aplicada, a ciência da guerra, tomou seu lugar. Rutherford interrompeu sua pesquisa fundamental, e seu laboratório foi reorganizado para trabalhos de detecção submarina (SACKS, 2002, p.299).

Apresentaremos agora algumas considerações sobre os aspectos que caracterizam o livro "Tio Tungstênio: memórias de uma infância química" como um material de divulgação científica. A primeira característica que nos leva a considerar a referida obra como material de divulgação científica reside no fato de a mesma ter sido publicada no formato de um livro, o que mostra o objetivo de atingir um público amplo, além do empenho do autor em definir os termos científicos e estabelecer analogias:

A condutividade dos metais foi atribuída a um 'gás' de elétrons livres e móveis, facilmente separáveis de seus átomos originais - isso explicava por que um campo elétrico podia puxar uma corrente de elétrons móveis através de um fio. Esse oceano de elétrons livres, na superficie de um metal, também podia explicar seu brilho especial... (SACKS, 2002, p.302).

Os principais elementos que nos permitiram fazer tal identificação são o uso da primeira pessoa e a tentativa de estabelecer um diálogo com o leitor, incomuns nos textos científicos. A seguir temos um exemplo em que o autor usa suas impressões pessoais sobre certos aspectos abordados no texto:

Aprender sobre isso foi o terceiro êxtase de minha vida, ao menos de minha vida 'química' (...) Mas o terceiro, a meu ver, foi em certos aspectos, o mais espantoso, pois contradizia (ou parecia contradizer) toda a ciência clássica que eu conhecia, e tudo o que eu sabia sobre racionalidade e causalidade (SACKS, 2002, p.297). 
Outra forma que explicita a tentativa do autor em atingir um público mais amplo é o uso de expressões coloquiais e até informais. Vejamos um exemplo:

A excelência e a rapidez do trabalho de Moseley, todo ele feito em poucos meses entre 1913-4, causou reações contrastantes entre os químicos. Quem era aquele fedelho, pensaram alguns químicos mais velhos... (SACKS, 2002, p.295, grifo nosso).

Percebemos também a intenção do autor em estabelecer um diálogo com o leitor em diversos pontos do texto. Esta simulação de diálogo é feita através de interrogações, seguidas das respostas, como se o leitor houvesse perguntado:

O que fazia os metais serem metálicos? A estrutura eletrônica explicava porque o estado metálico parecia ser fundamental, ter um caráter tão diferente de qualquer outro. Algumas das propriedades mecânicas dos metais, suas densidades e pontos de fusão elevados, agora podiam ser explicados segundo a intensidade com que os elétrons estavam ligados ao núcleo (SACKS, 2002, p.302).

Entendemos que, mesmo sem haver restrições ao público a que esta obra se destina, percebemos que ela não é direcionada a um público completamente leigo, uma vez que exige certos conhecimentos básicos de química. No entanto, através das explicações existentes, conforme exemplificamos anteriormente, percebemos certa preocupação demonstrada pelo autor em tornar inteligiveis os conceitos científicos apresentados no texto. 


\section{OBJETIVOS}

Este trabalho tem como objetivo investigar o funcionamento da leitura de textos de divulgação científica no ensino superior de química, em condições determinadas. Para compreender esse funcionamento, buscamos indicadores de como esse tipo de leitura pode produzir sentidos em classes do ensino superior e sugerir possibilidades de leitura do discurso da divulgação científica neste nível de ensino. Para tanto, aplicamos uma proposta de ensino pautada na utilização de textos extraídos do livro de divulgação científica "Tio Tungstênio: memórias de uma infância química", de autoria de Oliver Sacks (2002), na disciplina Fundamentos de Quimica Estrutural, oferecida aos ingressantes do curso de Bacharelado em Química do Instituto de Química de São Carlos, Universidade de São Paulo.

Esta pesquisa parte da hipótese que a diversidade de informações presente nos textos de divulgação científica pode abrir um leque de interpretações, possibilitar a contraposição de visões e facilitar a 
manifestação das opiniões e interesses dos estudantes e, dessa forma, favorecer-lhes uma formação mais humanística.

Tal como outros pesquisadores da área de educação em ciências (RICON; ALMEIDA, 1991; ALMEIDA, 1998) - que estudaram o mecanismo de textos de divulgação cientifica em ambientes de ensino - investigamos o funcionamento da leitura do referido livro em relação a diversos aspectos inerentes ao processo de ensino-aprendizagem, como as dinâmicas discursivas em sala de aula, a constituição dos estudantes como autores e suas impressões no que diz respeito à realização da atividade. Para tanto, analisamos os seguintes dados, coletados durante a aplicação da proposta: questões formuladas pelos estudantes durante as atividades de leitura, textos produzidos por eles referentes aos capítulos estudados e respostas dadas a questionários aplicados ao final das atividades.

Os referenciais teóricos que guiaram este trabalho foram os da Análise de Discurso, da escola francesa - como tem sido divulgada por Eni Orlandi (1996a, 1996b, 2000, 2002) - especialmente as noções de tipologia do discurso para a identificação dos diferentes tipos de discursos presentes nas questões formuladas pelos alunos, e autoria para a verificação do exercício da função autor pelos estudantes na produção de seus textos. 


\section{REFERENCIAIS TEÓRICOS}

Para a análise dos dados, utilizamos o referencial teórico da Análise de Discurso da escola francesa. A importância que a Análise do Discurso dá às condições de produção na atividade discursiva, faz com que consideremos esse referencial adequado para buscar compreendermos o funcionamento da leitura de divulgação científica em determinadas situações de ensino. Para tanto, nos apoiamos nestes pressupostos e, sobretudo, no que diz respeito à idéia de autoria e tipologia do discurso, na perspectiva divulgada por Eni Orlandi, a partir dos trabalhos de Michel Pêcheux. Alguns conceitos importantes e que eventualmente serão apresentados ao longo das análises e das considerações feitas no Capítulo Resultados e Discussão encontram-se a seguir. 


\title{
3.1 Análise do Discurso
}

Surgida no contexto francês do final dos anos 60, a Análise do Discurso (AD), segundo Maldidier (2003), teve uma dupla fundação nas figuras de Jean Dubois e Michel Pêcheux. Ligados ao marxismo e à política, no final dos anos 60 ambos publicaram trabalhos considerados como "Manifestos da Análise do Discurso": "Lexicologia e Análise de Enunciado", de Dubois e "Análise Automática do Discurso", de Pêcheux. Estes livros inauguraram uma visão transdisciplinar na teoria do discurso. De acordo com Gregolin (2001), nas duas obras, a problemática é a relação entre o objeto (discurso) e o dispositivo de análise, porém, a natureza das preocupações e as trajetórias de ambos são diferentes:

\begin{abstract}
Se o marxismo e a lingüística presidem o nascimento da $A D$, nesse final dos 60, Dubois e Pêcheux adotarão diferentes perspectivas: para Dubois a $\mathrm{AD}$ seria uma continuação natural da Lingüística, articulando-lhe um modelo sociológico para alcançar a enunciação; já para Pêcheux a preocupação era a epistemologia, o corte saussureano, a reformulação da parole e a conseqüente interrogação sobre o dispositivo teórico para a análise das condições de possibilidades do discurso, dos processos discursivos (GREGOLIN, 2001, p. 11-12).
\end{abstract}

Partindo de uma relação necessária entre o dizer e as condições de produção desse dizer, a $\mathrm{AD}$ proposta por Pêcheux insere a exterioridade como elemento constitutivo dos sentidos, exigindo, portanto, um deslocamento teórico que vai recorrer a conceitos exteriores ao domínio da lingüística, para dar conta da análise de unidades mais complexas da linguagem. Acredita-se então, que a fundação teórica da $\mathrm{AD}$, hoje conhecida como linha francesa, se deve ao conjunto de textos publicados por Michel Pêcheux entre 1969 e 1975, que explicitaram a base de seu pensamento, 
mas cujos temas, conceitos e análise sofreram constante reformulação pelo próprio autor e pelos trabalhos posteriores da área.

Assim, refletindo sobre as articulações significativas entre o homem, a história e a sociedade e interpretando a relação do homem com a sua realidade, a $\mathrm{AD}$ nasceu com um caráter interdisciplinar: as análises procuravam de certa forma, relacionar lingüística, marxismo e psicanálise (GREGOLIN, 2003).

Segundo Gama (2005), o problema metodológico deste dispositivo teórico-analítico não está na elaboração de técnicas para coletar os enunciados, mas na leitura dos mesmos. Orlandi (1996a), em contrapartida, acredita que para a $\mathrm{AD}$ não existem dados enquanto tal, uma vez que eles resultam de uma construção, de um gesto teórico. A autora afirma ainda que na $\mathrm{AD}$ a análise precede, em sua constituição, a própria teoria. Ou seja, é porque o analista tem um objeto a ser analisado que a teoria vai se impondo. Não há uma teoria já pronta que sirva de instrumento para a análise (ORLANDI, 2002).

Os estudos lingüísticos modernos apresentaram-se inicialmente como estudos lingüísticos do sistema, ou seja, tanto com a lingüística estrutural como com a gramática gerativa, procurou-se descrever a língua de maneira abstrata, fora de qualquer contexto de uso. Contudo, a partir da década de 70 tem ficado cada vez mais claro que as questões de linguagem se estendem muito além das questões mais peculiares da gramática, para incorporar as dimensões discursivas que incluem os interlocutores, as relações que se estabelecem entre eles, os conhecimentos que partilham ou não, as intenções e os propósitos específicos dos textos, as circunstâncias sociais em 
que se manifestam. Desta forma, a perspectiva da $\mathrm{AD}$ vai de encontro à idéia de que a língua seja apenas um instrumento para transmitir informações ou expressar livremente o pensamento. Ao contrário, ela baseia-se em uma concepção de linguagem como forma de ação e prática social, que contribui para um grande avanço teórico e metodológico no campo dos estudos da linguagem (RODRIGUES, 2001).

A AD se opõe à análise de conteúdo pois, segundo Orlandi (2002), esta última procura extrair sentidos do texto, respondendo à questão: o que este texto quer dizer? De maneira diferente, a $\mathrm{AD}$ considera a não transparência da linguagem e a não unicidade dos sentidos. Deste modo não procura atravessar o texto para encontrar um sentido do outro lado, a questão colocada é: como este texto significa?

Como seu próprio nome indica, a $\mathrm{AD}$ não trata da língua nem da gramática, ela trata do discurso. E a palavra discurso, "etimologicamente, tem em si a idéia de curso, de percurso, de correr por, de movimento", deste modo o discurso é "a palavra em movimento, prática de linguagem" (ORLANDI, 2002, p.15).

O trabalho com o discurso implica na construção de sentidos com base nas condições de produção do mesmo. Tais condições de produção podem ser entendidas, no sentido mais estrito, como sendo o contexto imediato de enunciação e, considerando um sentido mais amplo, estas podem incluir o contexto sócio-histórico-ideológico, e é neste segundo contexto que podem ser apreendidos os efeitos desses sentidos (ORLANDI, 2002). 
Segundo Orlandi (2002), as condições de produção, que constituem os discursos, funcionam de acordo com certos fatores. Um deles é o que se chama de relação de sentidos. Os sentidos resultam de relações, um discurso aponta para outros que o sustentam, assim como para dizeres futuros. Por outro lado, segundo o mecanismo da antecipação, todo sujeito tem a capacidade de antecipar-se a seu interlocutor quanto ao sentido que suas palavras produzem. Segundo a relação de forças, o lugar pelo qual o sujeito fala é constitutivo do que ele diz. Esses mecanismos de funcionamento do discurso, segundo a autora, constituem as formações imaginárias. Pêcheux (1997, p.82) define a formação imaginária como "uma antecipação do que o outro vai pensar, na qual cada enunciado vem carregado da imagem que fazemos de nós mesmos e do outro".

Assim, por conseqüência, o sentido não existe em si, mas é determinado pelas posições ideológicas colocadas em jogo no processo sócio-histórico em que as palavras são produzidas. Para Orlandi (2002, p.43), os sentidos das palavras se modificam à medida que se modificam as posições daqueles que a empregam, "elas 'tiram' seu sentido dessas posições, isto é, em relação às formações ideológicas nas quais essas posições se inscrevem".

A ideologia, que caracteriza um discurso diferenciando-o de outros, pode ser observada em um texto através dos sentidos produzidos em decorrência da escolha das palavras empregadas, da disposição das mesmas nos enunciados, da ressignificação a que são submetidas. Estes aspectos são inerentes à construção de sentidos e às formações ideológicas que, 
historicamente, implicam formações discursivas (FERNANDES; FERREIRA, 2001).

Deste modo, cabe aqui definir formação discursiva, que segundo Orlandi (2002, p.43), corresponde àquilo que "numa formação ideológica dada - a partir de uma posição dada em uma conjuntura sócio-histórica dada - determina o que pode e deve ser dito". De acordo com Pêcheux (1995, p.160), “os indivíduos são interpelados em sujeitos falantes pelas formações discursivas que representam 'na linguagem' as formações ideológicas que lhes são correspondentes".

Para Foucault (1972) todo enunciado pertence a uma formação discursiva. O autor formula a sua definição mais precisa do que entende por formação discursiva como um conjunto de enunciados que mantêm uma regularidade:

Isto é, conjuntos de performances verbais que não estão ligadas entre si, ao nível das frases, por laços gramaticais (sintáticos ou semânticos); que não estão ligados entre si, ao nível das proposições, por laços lógicos (de coerência formal ou encadeamentos conceituais); que tampouco estão ligados, ao nível das formulações, por laços psicológicos (que sejam a identidade das formas de consciência, a constância das mentalidades, ou a repetição de um projeto); mas que estão ligados ao nível dos enunciados (FOUCAULT, 1972, p. 144).

Pêcheux (1995, p.162) formulou os conceitos de interdiscurso e intradiscurso, sendo o primeiro entendido como algo que "fala sempre antes, em outro lugar e independentemente, isto é, sob a dominação do complexo das formações ideológicas", delimitando o espaço discursivo e ideológico no qual se desdobram as formações discursivas em função de relações de dominação, subordinação e contradição. Enquanto o intradiscurso 
representa o fio do discurso, o funcionamento do discurso em relação a ele mesmo, e se encontra no nível da formulação.

Para Orlandi (2002), o interdiscurso representa o saber discursivo, que torna possivel todo dizer e que retorna sob a forma de pré-construído, o já-dito que está na base do dizível, sustentando cada tomada da palavra. O interdiscurso compõe o conjunto de todos os sentidos já ditos por alguém, em algum lugar, em outros momentos e que determinam o que dizemos.

Assim, se os sentidos são aqueles produzidos na interação, é preciso aceitar que na linguagem não há o sentido original, tudo já foi dito anteriormente e faz parte dos nossos conhecimentos adquiridos-pré-construídos e que, com o tempo, são esquecidos (PÊCHEUX, 1995). Isso propicia considerarmos que a origem do discurso está em cada um de nós (SARGENTINI, 2001).

Orlandi (2002) apresenta também uma definição discursiva de ideologia, indicando que a presença desta é atestada pelo fato de não haver sentido sem interpretação. De acordo com a autora, a ideologia é a condição para a constituição do sujeito e dos sentidos, o indivíduo é interpelado pela ideologia para que se produza o dizer. Por sua vez, a evidência do sujeito apaga este fato e dá a ele a realidade como sistema de significações percebidas, funcionando pelos chamados "esquecimentos". Pêcheux (1997) distingue duas formas de esquecimentos no discurso, aqui concebidos de maneira diferente à idéia de esquecimento como um distúrbio de memória. Tais esquecimentos $-o \mathrm{n}^{\circ} 1$ e o $\mathrm{n}^{\circ} 2$ - são caracterizados por produzir uma ilusão discursiva do sujeito (ORLANDI, 2002). 
O esquecimento $\mathrm{n}^{\circ} 1$ também é conhecido como esquecimento ideológico, é da ordem do inconsciente. Por este esquecimento temos a ilusão de ser a origem daquilo que dizemos quando, na verdade, retomamos sentidos já existentes. Embora sejam realizados por nós, “os sentidos apenas se representam como originando-se em nós, são determinados pela maneira como nos inscrevemos na lingua e na história e é por isso que significam e não pela nossa vontade" (ORLANDI, 2002, p.35).

O esquecimento $n^{\circ} 2$, por sua vez, refere-se a uma seleção lingüística pré-consciente feita pelo sujeito. Nesta seleção, convém ao sujeito a escolha de determinadas formas lingüísticas e o esquecimento de outras com o intuito de produzir a ilusão de que o seu discurso é objetivo e consciente. O entendimento destes aspectos nos leva a concluir que tanto a crença que o sujeito tem de que o sentido já existe como tal e de que possui o domínio de seu discurso são efeitos ideológicos (ORLANDI, 2002).

Orlandi (2002) afirma que esses esquecimentos não são defeitos, mas uma necessidade para que a linguagem funcione nos sujeitos e na produção de sentidos:

\footnotetext{
Os sujeitos "esquecem" que já foi dito - e este não é um esquecimento voluntário - para, ao se identificarem com o que dizem, se constituírem em sujeitos. É assim que suas palavras adquirem sentido, é assim que eles significam retomando palavras já existentes como se elas se originassem neles e é assim que sentidos e sujeitos estão sempre em movimento, significando sempre de muitas e variadas maneiras. Sempre as mesmas mas, ao mesmo tempo, sempre outras (ORLANDI, 2002, p.36).
}

Considerando as noções acima descritas, a última contribuição da AD a qual destacamos é a concepção de leitura. A leitura na perspectiva da AD é considerada o momento crítico da constituição do texto, pois é o momento privilegiado do processo de interação verbal, aquele em que os interlocutores, 
ao se identificarem como tal, desencadeiam o processo de significação. É nessa interação que os interlocutores instauram o espaço da discursividade.

A perspectiva discursiva na reflexão sobre leitura deve, conforme Orlandi (2000, p.8) submeter-se aos seguintes fatos:

i) Pensar a produção da leitura e, logo, a possibilidade de encará-la como possivel de ser trabalhada;

ii) A leitura, tanto quanto a escrita, faz parte do processo de instauração do(s) sentido(s);

iii) O sujeito-leitor tem suas especificidades e suas histórias;

iv) Tanto o sujeito quanto os sentidos são determinados historicamente e ideologicamente;

v) Há múltiplos e variados modos de leitura;

vi) A noção de que a nossa vida intelectual está intimamente relacionada aos modos e efeitos de leitura de cada época e segmento social.

A autora chama atenção para a existência das "histórias das leituras" que têm a ver com a historicidade que rege a relação dos sujeitos com os textos (história do sujeito-leitor) e com o fato de que há uma história de leituras que afeta o texto. Assim o mesmo leitor não lê o mesmo texto da mesma maneira em diferentes momentos e em condições distintas de produção de leitura, e o mesmo texto é lido de maneiras diferentes em diferentes épocas, por diferentes leitores:

Podemos mesmo dizer que as leituras têm suas histórias, no plural. Não há leituras previstas por um texto, em geral, como se o texto fosse fechado em si mesmo e auto-suficiente. Há leituras previstas para ele. Mas mesmo ao se reconhecer que há leituras previstas para um texto, importa cuidar-se para que não se petrifiquem essas 
leituras previstas, a fim de que possa acontecer a leitura nova, tanto quanto possivel (ORLANDI, 2000, p.88).

Por isso toda leitura tem sua história e conseqüentemente para um mesmo texto, leituras são possiveis em certas épocas e não foram em outras, ou as que não são possíveis hoje serão no futuro (GAMA, 2005). Desta forma, a leitura não tem a ver apenas com a situação em que ocorre, mas depende de outras leituras e do próprio contexto de vida do leitor.

\subsection{Tipologia do Discurso}

Orlandi (2000) sugere que, da observação da linguagem e em termos bastante gerais, a produção do discurso se faz na articulação de dois grandes processos, que seriam o fundamento da linguagem: o processo parafrástico e o processo polissêmico. O processo parafrástico permite a produção do mesmo sentido sob várias de suas formas (matriz da linguagem) e o processo polissêmico é o responsável pelo fato de que são sempre possiveis sentidos diferentes, múltiplos (fonte da linguagem). Ou seja, de um lado existe um constante retorno a um mesmo dizer sedimentado - a paráfrase - e, de outro, há no texto uma tensão que aponta para o rompimento. Esta é uma manifestação da relação entre o homem e o mundo (a natureza, a sociedade, o outro), manifestações da prática e do referente na linguagem. Há um conflito entre o que é garantido e o que tem de se garantir. A polissemia é essa força na linguagem que desloca o mesmo, o garantido, tensão entre o texto e o contexto histórico-social; o conflito entre o "mesmo" e o "diferente" (ORLANDI, 2000). 
Segundo Orlandi (2002), são muitos os critérios pelos quais se constituem tipologias na $\mathrm{AD}$. Uma das mais comuns é a que reflete as distinções institucionais e suas normas: discurso político, jurídico, religioso, jornalístico, científico, entre outros. Também as diferenças entre disciplinas podem estar na base das tipologias: o discurso histórico, sociológico, biológico etc. Há ainda diferenças relativas a estilos, gêneros, subdivisões no interior dos já categorizados e assim por diante. No entanto, Orlandi (2002) ressalta que, ao analista, a tipologia pode ser útil em alguns momentos, mas não faz parte de suas preocupações centrais, pois o que caracteriza o discurso, antes de tudo, não é seu tipo, é seu modo de funcionamento.

Deste modo, a autora procurou estabelecer um critério para distinguir diferentes modos de funcionamento do discurso, tomando como referência elementos constitutivos de suas condições de produção e sua relação com o modo de produção dos sentidos. Assim ela distinguiu os discursos (ORLANDI, 2002, p.86):

i) discurso autoritário, aquele em que a polissemia é contida, o referente está apagado pela relação de linguagem que se estabelece e o locutor se coloca como agente exclusivo, apagando também sua relação com o interlocutor;

ii) discurso polêmico, aquele em que a polissemia é controlada, o referente é disputado pelos interlocutores, e estes se mantêm em presença, numa relação tensa de disputa pelos sentidos;

iii) discurso lúdico, aquele em que a polissemia está aberta, o referente está presente como tal, sendo que os interlocutores se expõem aos 
efeitos dessa presença inteiramente não regulando sua relação com os sentidos.

O exagero do discurso autoritário é a ordem no sentido militar, o do polêmico é a injúria e o exagero do lúdico é o non sense. Em nossa forma de sociedade atual, o discurso autoritário é dominante, o polêmico é possível e o lúdico é ruptura (ORLANDI, 2000).

De acordo com a autora, a noção de tipo é necessária como princípio de classificação para o estudo do uso da linguagem, ou seja, do discurso. Além de ser uma necessidade metodológica, as tipologias são de aplicação relativa, podendo ter uma maior ou menor generalidade: "o estabelecimento da tipologia tem a ver com os objetivos especificos da análise que se estiver empreendendo e com a adequação ao exemplar de linguagem que é objeto de análise" (ORLANDI, 1996b, p.152).

Orlandi (2000) ressalta que as tipologias devem ser interpretadas, pois não são nem de elaboração nem de aplicação mecânica. E que também não se devem estabelecer relações categóricas entre os tipos, é preferivel, antes, falar-se em tendências: há discursos que tendem para o tipo autoritário, ou tendem para o lúdico etc. Não há, assim, um discurso puramente autoritário, polêmico ou lúdico, a não ser idealmente.

Devemos observar, em geral, que esses tipos de discurso não têm de existir necessariamente de forma pura. Há mistura de tipos e, além disso, há um jogo de dominância entre eles que deve ser observado em cada prática discursiva. Isso significa que é preciso analisar o funcionamento discursivo para se determinar a dinâmica desses tipos: às vezes todo o texto é um tipo, às vezes seqüências se alternam em diferentes tipos, outras vezes um tipo é usado em função do outro, outras vezes ainda eles se combinam, etc. (ORLANDI, 1996b, p.155-156). 
A autora acrescenta ainda que as denominações lúdico, autoritário e polêmico não devem levar a pensar que se está julgando os sujeitos desses discursos, como se fosse um juízo de valor. Essas denominações correspondem a uma descrição do funcionamento discursivo em relação a suas determinações histórico-sociais e ideológicas:

\begin{abstract}
Não se deve assim tomar, por exemplo, o lúdico no sentido do brinquedo mas do jogo da linguagem e não se deve tampouco tomar pejorativamente o autoritário como um traço de caráter do locutor, uma questão moralista, mas uma questão do fato simbólico (ORLANDI, 2002, p. 87).
\end{abstract}

\title{
3.3 Autoria
}

Compreender a autoria supõe compreender os procedimentos que os autores, pessoas físicas, lançam mão ao compor seus discursos. Por isso é que o autor pode ser entendido como princípio que confere unidade ao discurso (FOUCAULT, 2004).

Aquilo que dizemos deve ser compreendido levando em conta as devidas relações que o nosso discurso mantém com outros discursos circulantes em nossa cultura, determinados por certas práticas sociais: assim, quem fala, o faz a partir de um lugar na instituição que o legitima e autoriza. Logo, o discurso organiza-se sob tais normas que fixam o lugar daquele que fala (FOUCAULT, 2004). A autoria seria um dos procedimentos que controlam, selecionam, organizam e redistribuem o discurso.

No contexto da $\mathrm{AD}$ o autor não é entendido como o indivíduo falante que pronunciou ou escreveu um texto, mas como princípio de agrupamento do discurso, como unidade e origem de suas significações, como foco de sua coerência. Sem negar a existência de um autor como o indivíduo que 
articulou e escreveu o discurso, Foucault (2004) o descreve como aquele que incorpora uma função de autor, que coloca em prática o princípio de autoria previsto em sua cultura, ou seja, num dado enunciado, há uma "fala" que articula o que é dito de um lugar, de um ponto de vista, sob determinadas condições de produção. $O$ sujeito que se inscreve no dito não é necessariamente o indivíduo "produtor original" (o autor). Assim, o sujeito do enunciado configura-se como uma possibilidade de ser, uma representação, resultado de um procedimento de autoria.

Segundo Foucault (2000, p.46) a função autor é "característica do modo de existência, de circulação e de funcionamento de alguns discursos no interior de uma sociedade". Este autor distingue quatro características da função autor:

i) "A função autor está ligada ao sistema jurídico e institucional que encerra, determina, articula o universo dos discursos" (FOUCAULT, 2000, p.56). Ou seja, é um objeto de apropriação, nasce da necessidade de punição, de se conhecer a procedência de textos que pudessem ser considerados contraventores;

ii) A função autor "não se exerce uniformemente e da mesma maneira sobre todos os discursos, em todas as épocas e em todas as formas de civilização", considerando que nem sempre os textos pediram uma atribuição (FOUCAULT, 2000, p.56). Não é uma noção absoluta e imutável: a recepção do autor varia no tempo e no espaço, o nome pode ser considerado importante ou não segundo a forma de recepção e análise que cada tempo e local garantem na obra; 
iii) A função autor "não se define pela atribuição espontânea de um discurso ao seu produtor, mas através de uma série de operações específicas e complexas" que constroem "um certo ser racional a que chamamos autor" (FOUCAULT, 2000, p.56). Segundo o autor, a obra define-se, então, como resultado da operacionalização racional de um indivíduo e é parte de um projeto efetuado por alguém imerso em escolhas individuais e coletivas, ou seja, contextualmente influenciadas;

iv) A função autor não "reenvia pura e simplesmente para um indivíduo real, podendo dar lugar a vários 'eus' em simultâneo, a várias posições-sujeito que classes diferentes de indivíduos podem ocupar" (FOUCAULT, 2000, p.56). Foucault exemplifica a pluralidade de "eus" com um exemplo de um tratado de matemática, no qual o eu que fala no prefácio é diferente, tanto na sua posição como no seu funcionamento, daquele que fala numa demonstração e que surge sob a forma de um "eu concluo" ou "eu suponho", neste exemplo teríamos ainda um terceiro eu: aquele que fala do significado do trabalho, dos obstáculos encontrados, dos resultados obtidos, dos problemas que ainda se põem (MASSI, 2008).

Deste modo, percebemos que a função autor representa um lugar que em vez de ser definido de uma vez por todas e de se manter uniforme ao longo do texto, de um livro ou de uma obra, "varia - ou melhor, é variável o bastante para poder continuar idêntico em si mesmo, através de várias 
frases, bem como para se modificar a cada uma", daí a noção de função (FOUCAULT, 1972, p.109).

Tomando as reflexões de Foucault, Eni Orlandi (2000; 1996a) considera que a noção de autor é uma função da noção de sujeito, responsável pela organização do sentido e pela unidade do texto, produzindo o efeito de continuidade do sujeito. Desta forma, a autora estende esta noção para o uso corrente, enquanto função enunciativa do sujeito, distinta da de enunciador e de locutor, não se limitando, diferentemente de Foucault, a um "quadro restrito e privilegiado de produtores originais de linguagem" (ORLANDI, 1996a, p. 69).

\begin{abstract}
Em meu trabalho desloquei essa noção (autoria) de modo a considerar, à diferença de Foucault, que a própria unidade do texto é efeito discursivo que deriva do princípio de autoria. Dessa maneira, atribuimos um alcance maior e que especifica o principio da autoria como necessário para qualquer discurso, colocando-o na origem da textualidade. Em outras palavras: um texto pode até não ter um autor específico mas, pela função-autor, sempre se imputa uma autoria a ele (ORLANDI, 2002, p.75).
\end{abstract}

Para Orlandi (1996a) a função-autor se realiza toda vez que o produtor da linguagem se representa na origem, produzindo um texto com unidade, coerência, progressão, não-contradição e fim. Esta função, segundo ela, é tocada de modo particular pela história, pois o autor consegue formular, no interior do formulável, e se constituir com seu enunciado numa história de formulações.

Assim, a autora distingue a repetição empírica, repetição formal e repetição histórica. A repetição empírica refere-se ao exercício mnemônico, em que o indivíduo repete exatamente da forma como leu ou ouviu. A repetição formal trata do exercício gramatical, em que o indivíduo repete o que leu ou ouviu, dizendo a mesma coisa com palavras diferentes. $\mathrm{E}$ na repetição 
histórica ocorre a interpretação, pois o repetível aqui faz parte da memória constitutiva do sujeito, ele consegue formular e constituir seu enunciado no interior das repetições.

Deste modo, apenas na repetição histórica o indivíduo se constitui autor, pois a inscrição do dizer no repetível histórico, segundo Orlandi (1996a), é que traz para a questão do autor a relação com a interpretação, pois o sentido que não se historiciza é ininteligivel, ininterpretável, incompreensível.

Orlandi (2000) atenta para o fato de que a escola deve propiciar ao aprendiz a experiência de práticas que façam com que ele tenha o controle dos mecanismos com os quais está lidando quando escreve, deste modo, a escola, como lugar de reflexão, se constitui em lugar fundamental para a elaboração da experiência de autoria. 


\section{METODOLOGIA}

A metodologia de pesquisa adotada é do tipo qualitativa e assume um perfil de estudo de caso. O estudo de caso representa uma das formas de pesquisa qualitativa e nada mais é que o estudo de um caso, seja ele simples e específico, ou complexo e abstrato. O caso é sempre bem delimitado, devendo ter seus contornos claramente definidos no desenrolar do estudo (LÜDKE; ANDRÉ, 1986).

O motivo para a escolha deste formato de metodologia de pesquisa reside na importância do contato que tivemos com o grupo de estudantes e com o professor responsável pela disciplina na qual a proposta foi aplicada: SQM0406 - Fundamentos de Química Estrutural, disciplina teórica, quatro créditos, oferecida aos alunos ingressantes do curso de Bacharelado em Química do Instituto de Química de São Carlos, Universidade de São Paulo. Ao longo dos últimos três anos, esta disciplina tem sido ministrada a partir da realização de aulas expositivas acompanhadas de monitorias para 
resolução de exercícios e esclarecimento de dúvidas. Seu conteúdo programático abarca noções básicas da Química Estrutural: o átomo e as teorias atômicas (o modelo atômico de Dalton e a química quantitativa posterior a Dalton), tabela periódica e propriedades periódicas (periodicidade química e estrutura eletrônica), classificação das ligações químicas (ligações iônicas, ligações covalentes, regra do octeto e sua expansão, polaridade, polarizabilidade, forças e comprimentos de ligações covalentes); estruturas de Lewis e geometria das moléculas; líquidos e sólidos ${ }^{3}$.

É importante destacar a conveniência da aplicação da proposta na referida disciplina, uma vez que são contempladas no livro Tio Tungstênio: memórias de uma infância química assuntos que coincidem com o seu conteúdo programático. Ademais, trata-se de uma disciplina ministrada nos moldes tradicionais, portanto, a aplicação da proposta poderia vir a favorecer uma produção de sentidos que não são comuns em situações de ensino dessa natureza.

Descreveremos a seguir a caracterização dos sujeitos da pesquisa, as etapas de aplicação da proposta de ensino e os instrumentos de coleta de dados empregados.

\subsection{Sujeitos}

Para a caracterização dos sujeitos da pesquisa, elaboramos um questionário, com questões pertinentes a este trabalho, o qual foi respondido

Disponivel em: http://sistemas2.usp.br/jupiterweb/obterDisciplina?sgldis=SQM0406 \&verdis=1. Acesso em 29 abr. 2008. 
pelos estudantes no início do semestre letivo (APÊNDICE B). A disciplina tinha 64 alunos matriculados no primeiro semestre de 2007. Apenas 45 alunos cumpriram todas as etapas da proposta de ensino e foram tomados como sujeitos da pesquisa. Três deles desistiram de cursar a disciplina no decorrer do semestre e 16 alunos não participaram de pelo menos uma das atividades que constituíam a proposta.

Dentre os sujeitos, 24 são do sexo masculino e 21 do sexo feminino, a grande maioria nascida na região sudeste $(95,56 \%$ têm São Paulo como estado de origem e 2,22\% Minas Gerais); um aluno nascido na Inglaterra. A faixa etária dos estudantes, em sua maioria (97,78\%) encontra-se entre 17 e 22 anos, embora haja um aluno com 27 anos. Com relação à formação estudantil, verificamos que 21 deles concluíram o ensino fundamental em escolas públicas e 17 em escolas particulares. As respostas dadas por sete alunos não nos permitiram identificar em que tipo de escola haviam concluído o ensino fundamental. Verificamos que uma grande parte dos estudantes $(71,11 \%)$ concluiu o ensino médio em escolas particulares, enquanto que somente seis concluíram em escolas públicas. Assim como no ensino fundamental, não foi possível identificar na resposta de sete alunos em qual tipo de escola haviam concluído o ensino médio. Também é digno de nota que dois alunos iniciaram um curso de graduação em outras universidades e sete alunos freqüentaram colégios técnicos, quatro dos quais fizeram curso técnico de química.

Quanto aos hábitos de leitura, verificamos que a maioria dos alunos $(55,56 \%)$ declara ler de um a três livros por ano; $22,22 \%$ lêem de três a seis livros; $13,33 \%$ lêem mais de seis livros e somente $8,89 \%$ dos alunos lêem 
menos de um livro ao ano. Verificamos também que os estudantes lêem revistas com maior freqüência $(40,35 \%)$, enquanto o restante se divide em jornais e livros (ambos 29,82\%). Ao perguntarmos com que finalidade os estudantes liam; $84,44 \%$ declararam que liam por prazer enquanto que apenas $15,56 \%$ dos alunos declararam que liam por obrigação. Uma quantidade significativa de alunos $(62,22 \%)$ considera importante a leitura e $44,44 \%$ assinam algum tipo de jornal ou revista. Constatamos que $75,56 \%$ dos estudantes liam quando crianças, especialmente revistas em quadrinhos e $57,78 \%$ afirmam reler algum livro ou revista quando esta leitura lhes é agradável. Por fim, quando perguntamos aos alunos qual a relação deles com a leitura no momento em que estão estudando; grande percentual $(77,78 \%)$ afirmou que a fazem por obrigação e, na maioria de suas respostas, declararam que quando lêem por outro motivo que não seja este, a relação com a leitura é muito mais prazerosa.

\subsection{Aplicação da Proposta}

A proposta para a utilização de textos de divulgação científica na disciplina Fundamentos de Química Estrutural foi por nós aplicada em parceria com o professor responsável pela disciplina. Para que a proposta de ensino fosse colocada em execução, inicialmente foram selecionados, pelo professor, dois capítulos do livro Tio Tungstênio: Memórias de uma Infância Química. Foi solicitado a este que, em sua escolha considerasse capítulos cujos conteúdos guardassem relações com a ementa da disciplina. Os capitulos selecionados foram os seguintes: Luz brilhante (capitulo 24) e $O$ 
jardim de Mendeleiev (capítulo 16). Vale destacar que as atividades com a leitura de cada um dos capitulos foram realizadas no mesmo período em que os assuntos neles abordados foram ministrados em sala de aula.

No início do semestre de aplicação da proposta os alunos foram informados que trabalhariam com textos de divulgação científica durante o período letivo em duas ocasiões, em horários dedicados às monitorias (horários extraclasse, duas horas de duração); eles tomaram conhecimento que os trabalhos realizados nessas ocasiões seriam por nós coordenados, com o acompanhamento do professor. Convém lembrar que, para a realização das atividades extraclasse, devido ao número elevado de alunos matriculados na disciplina, a turma foi dividida em duas: uma com 24 e outra com 21 alunos.

Na primeira etapa de aplicação da proposta foi solicitado que os alunos fizessem a leitura dos três capitulos iniciais do livro: Tio Tungstênio, 37 e Exilio. Esta leitura foi necessária para que os estudantes pudessem se familiarizar com os personagens da história. Nesta mesma etapa, os alunos responderam a um questionário com as impressões iniciais da leitura dos capítulos (APÊNDICE C).

Na segunda etapa, no primeiro encontro extraclasse, as informações presentes nos capítulos iniciais foram discutidas em sala. Em seguida, fizemos uma exposição oral com o intuito de apresentar aos alunos a vida e a obra literária de Oliver Sacks e também algumas características do livro em pauta. Os alunos, divididos em grupos de cinco a seis componentes, fizeram a leitura do capítulo Luz brilhante. Vale salientar que esta divisão de grupos não foi feita de maneira aleatória. Lançamos mão da divisão 
anteriormente realizada, com o mesmo grupo, por um dos integrantes do Grupo de Pesquisa em Ensino de Química do Instituto de Química de São Carlos, que desenvolveu seu trabalho baseado em métodos cooperativos de aprendizagem. Concluída a leitura em grupo, os alunos elaboraram perguntas na forma escrita referentes aos assuntos apresentados no texto. Por fim, os alunos responderam a um questionário sobre as impressões que tiveram da atividade realizada (APÊNDICE D).

Em um segundo encontro, foram adotados os mesmos procedimentos para o capítulo $O$ jardim de Mendeleiev, com pequenas diferenças: solicitamos aos alunos uma leitura prévia do capítulo a ser estudado e acrescentamos uma pergunta ao questionário sobre as impressões em relação à atividade realizada, pedíamos nesta questão que os alunos comparassem a primeira atividade com a segunda (APÊNDICE E). Esta modificação atendeu a solicitações do primeiro questionário - um período maior para a leitura do capítulo.

Na última etapa de aplicação da proposta foi solicitada aos alunos a redação de dois textos que fizessem alusão aos dois capítulos estudados nas atividades realizadas (APÊNDICE F). Os textos, de gênero livre, deveriam ser dirigidos a um leitor com as características de um calouro do curso de graduação em química. Também lhes foi solicitado que respondessem a um questionário sobre diversos aspectos pertinentes à proposta aplicada, de modo que suas impressões e sugestões pudessem ser analisadas, visando a melhoria da proposta de ensino (APÊNDICE G). Ambas as atividades que constaram desta última etapa foram realizadas em horário extraclasse. 
Estabelecemos a condição de produção de texto em gênero livre para dar ao aluno a possibilidade de posicionar-se com maior liberdade e criatividade na produção do seu texto. Consideramos também os resultados apontados pelos trabalhos de Santos e Queiroz (2007) e de Oliveira (2001), os quais - a partir da solicitação de redação de textos de gêneros variados em atividades oferecidas no ensino de ciências - verificaram que essa liberdade aumentou o interesse de alguns alunos pela escrita, levando-os a expor os conteúdos estudados com maior facilidade.

É importante lembrar que todos os encontros nos quais utilizamos os textos de divulgação foram gravados em áudio e vídeo e as falas dos envolvidos no processo foram transcritas, para preservar, ao máximo, suas características originais. Convém recorrer às reflexões de Carvalho (1996) sobre a tomada de dados com auxilio de gravações em vídeo. Para a autora (1996, p.9), o exame do vídeo "introduz uma mudança de paradigma na análise dos dados, possibilitando aos investigadores aprofundar suas reflexões teóricas numa relação dialógica com os dados empíricos”. Ela também chama atenção para o fato de a gravação em vídeo permitir que se possa ver e rever as aulas quantas vezes forem necessárias, o que adiciona uma coleção de dados novos às pesquisas, dados que não seriam registrados pelo melhor observador situado na sala de aula.

\subsection{Coleta de Dados}

A coleta dos dados foi realizada por meio do acompanhamento das atividades realizadas pelos alunos nos encontros nos quais foram utilizados 
os textos de divulgação científica e nas aulas ministradas em horário regular na disciplina Fundamentos de Quimica Estrutural. O seguinte conjunto de dados foi coletado durante a realização da pesquisa:

i) Todo o material escrito produzido pelos alunos a partir da realização da atividade com os textos de divulgação científica (perguntas elaboradas pelos alunos, textos finais produzidos pelos alunos, questionários respondidos pelos alunos);

ii) Arquivos de áudio e vídeo dos encontros nos quais foram utilizados os textos de divulgação;

iii) Arquivos de áudio das aulas ministradas em horário regular na disciplina Fundamentos de Quimica Estrutural e registro, em um caderno de campo, de observações sobre acontecimentos considerados relevantes no decorrer das aulas. Com esta coleta de informações registrada no caderno de campo pretendiamos nos inteirar de aspectos característicos do cotidiano escolar.

Cabe ressaltar que as impressões/sugestões dadas pelos estudantes ao questionário aplicado no final das atividades foram analisadas com o intuito de avaliarmos a potencialidade da proposta no desenvolvimento de habilidades desejáveis em alunos de graduação e também com o intuito de buscarmos subsídios para seu aprimoramento, bem como indícios da sua receptividade entre os alunos. 


\section{RESULTADOS E DISCUSSÃO}

Pautamos o nosso trabalho na investigação sobre o funcionamento da leitura de dois textos de divulgação científica - extraídos do livro Tio Tungstênio: memórias de uma infância química (SACKS, 2002) - em atividades realizadas com estudantes de graduação em química. Deste modo, esta investigação se deu a partir da análise das questões formuladas pelos estudantes decorrentes da leitura dos referidos textos, sob a perspectiva da Análise do Discurso na linha francesa, com relação à tipologia do discurso, que nos permitiu observar características dos discursos autoritário, polêmico e lúdico presentes na formulação de cada uma delas.

A noção de autoria, também na perspectiva da Análise do Discurso, foi empregada na análise dos textos produzidos pelos alunos, solicitados ao final da atividade, com o intuito de verificar indícios de repetição empírica, formal e histórica em seu teor. 
Apresentaremos também neste capítulo as impressões dos estudantes com relação à estratégia de ensino, através das respostas dadas por eles a três questionários: dois deles respondidos no final de cada atividade (APÊNDICES D e E) e um terceiro no final do semestre de aplicação da proposta (APÊNDICE G).

\subsection{Questões formuladas pelos estudantes}

A partir da análise das questões formuladas pelos alunos decorrentes da leitura dos textos de divulgação científica, procuramos investigar se características do discurso pedagógico podem ser deslocadas pelo funcionamento da leitura de divulgação científica em uma classe do ensino superior de química. O discurso pedagógico (DP), segundo Orlandi (1996b), é definido como um discurso autoritário em seu funcionamento, pois se dissimula como transmissor de informações, e faz isso caracterizando essa informação sob a assinatura da cientificidade.

De acordo com Silva e Almeida (2005), o funcionamento do DP constitui uma memória na qual professor e alunos se inscrevem para poder dizer determinadas coisas e não outras, produzir determinados sentidos e não outros e se significam respectivamente enquanto professores e alunos. Para Orlandi (1996b, p.31), "o professor é institucional e idealmente aquele que possui o saber e está na escola para ensinar, o aluno é aquele que não sabe e está na escola para aprender". Deste modo, a autora propõe que para interferir no caráter autoritário do DP é preciso atingir seus efeitos de sentido, torná-lo um discurso polêmico, e isso, da parte do aluno, 
significaria exercer sua capacidade de discordância, isto é, não aceitar aquilo que o texto sugere, constituir-se ouvinte e construir-se como autor na dinâmica da interlocução.

Para verificar os possíveis efeitos de deslocamentos ocasionados pela leitura dos textos, analisamos tanto as perguntas feitas pelos estudantes nas aulas tradicionais ministradas na disciplina na qual a proposta foi aplicada, como as perguntas elaboradas durante as atividades com os textos. Para tanto, categorizamos inicialmente as perguntas dos alunos segundo o trabalho de Silva (2002), a partir da configuração de diferentes objetos de conhecimento pelos estudantes. A seguir, definimos cada um dos tipos de questões formuladas pelos alunos e nos valemos da tipologia do discurso, proposta por Orlandi (1996b), de modo a verificar para qual tipo de discurso cada uma destas categorias tende:

i) Matemática: questões que se relacionam direta ou indiretamente com a linguagem matemática. Entendemos que questões como estas tendem à instauração de um discurso autoritário, uma vez que na sua formulação ocorre a permanência do sentido único - fazer cálculos e obter resultados numéricos - e a verdade é imposta pelo locutor, ou seja, no imaginário dos alunos, o professor é o único que está apto a esclarecer estes questionamentos;

ii) Metalinguagem: questões que requisitam a definição de expressões, palavras, conceitos. Perguntas desta natureza são as mais freqüentes no DP e o caracterizam fortemente como um discurso autoritário, no qual observamos uma polissemia contida e uma reversibilidade estancada, pois a metalinguagem, segundo Orlandi (1996b), adquire 
um estatuto de voz onipotente, exclusiva, a imagem de um discurso preciso e coerente;

iii) Fenômenos: questões que dizem respeito a fatos do mundo natural, sejam eles observáveis ou derivados de um modelo. Assim como nas categorias anteriores, também encontramos características de um discurso autoritário neste tipo de pergunta, pois o objeto de estudo encontra-se encoberto pelo dizer e o falante o domina, ou seja, estas questões dizem respeito a aspectos que compõem as condições de produção do conhecimento científico de forma implícita, ocultada pelo DP;

iv) Processos: questões relacionadas a aspectos da produção do conhecimento científico. Questões que configuram este tipo de objeto de conhecimento indicam deslocamentos do discurso autoritário, pois o referente é a produção da ciência, as idéias científicas, o trabalho dos cientistas. Observamos nesses discursos a introdução da polissemia, ou seja, uma tendência ao discurso polêmico.

É importante lembrar que - assim como mencionado anteriormente e conforme defende Orlandi (1996b) - a noção de tipo é necessária como princípio de classificação, mas deve-se tomar o cuidado de não restringir a análise à tipologia e considerar os tipos como uma noção endurecida e estagnada metodologicamente. A autora também acrescenta que não há nunca um discurso puramente lúdico, polêmico ou autoritário, e que no mesmo discurso podem estar presentes os três tipos alternados. 
Vale ressaltar que, assim como Silva (2002), entendemos a formulação de questões como uma maneira de constituir sentidos, desta forma, a análise recai nas próprias questões e não nas suas respostas.

$\mathrm{Na}$ apresentação dos dados não atribuímos os nomes dos alunos às suas respectivas perguntas, primeiro porque eles realizaram essa etapa da atividade em grupos, segundo porque nossa análise não pretende seguir os discursos dos estudantes específicos e, portanto, a identificação não se faz necessária.

\subsubsection{Nas aulas tradicionais}

Fizemos um acompanhamento das aulas ministradas na disciplina na qual a proposta foi aplicada e registramos, em um caderno de campo, as perguntas feitas pelos estudantes no decorrer dessas aulas. Tal acompanhamento foi feito com o intuito de nos inteirarmos de características do cotidiano escolar dos sujeitos da pesquisa e, deste modo, tecer considerações a respeito de aspectos do DP presentes em uma classe do ensino superior de química, que o caracterizam como autoritário em seu funcionamento.

Verificamos que as questões formuladas pelos estudantes durante as aulas tradicionais anunciaram basicamente três objetos de conhecimento: fenômenos $(22,81 \%)$; matemática $(21,05 \%)$ e metalinguagem $(56,14 \%)$.

Durante as aulas, em especial aquelas que tratavam do assunto Teoria Atômica, observamos perguntas que se relacionavam diretamente com a linguagem matemática, como indicadas a seguir. 
Se Ze corresponde à carga do núcleo, porque ele está ao quadrado?

Por que o sinal é negativo?

E_é um produto?

$O$ L não é ao quadrado?

O senhor não poderia dar outro exemplo para ficar mais claro o cálculo da carga formal?

Por que quando eu foco pela fórmula da carga formal não dá a mesma coisa?

Esse sinal negativo que o senhor colocou é só para diferenciar do h1?

A justificativa para tais formulações pode estar no fato dessas aulas terem sido conduzidas pelo professor através da demonstração dos cálculos feitos pelos cientistas envolvidos nos trabalhos relacionados à teoria atômica. Percebemos que as perguntas formuladas indicam características de um discurso puramente autoritário, pois estão diretamente veiculadas a um sentido único: o uso operacional das fórmulas matemáticas - representação bastante freqüente em aulas do ensino superior de química. No entanto, a matemática deveria aparecer como parte intrínseca do raciocinio e do trabalho de um cientista, da formulação de suas hipóteses. Entendemos que fórmulas fazem parte da química e se relacionam a atividades que envolvem fazer cálculos, obter resultados numéricos, porém, acreditamos que pensar a fórmula matemática como o resultado de um trabalho científico talvez seja mais relevante do que a operacionalização.

Em quantidade semelhante às questões que envolviam a linguagem matemática, tivemos perguntas que diziam respeito a fenômenos naturais, conforme apresentamos a seguir:

Essa força de repulsão elétron-elétron é o que não deixa o elétron chegar no núcleo? Qual é a relação entre o experimento anterior e o do modelo orbital? O número de elétrons vai interferir se vai ter campo magnético ou não? Isso funciona por causa da geometria da molécula? $\mathrm{Na}$ disposição dos elétrons do flúor, o que ocorre é um rearranjo? Isso não influencia na atração? Tem a ver com a blindagem? 
Observamos nestas perguntas a necessidade dos alunos em visualizar e conceber situações concretas, e indicam suas dificuldades em abstrair e relacionar diferentes fenômenos. Porém, consideramos que os enunciados apresentados tendem a um discurso autoritário, pois envolvem saberes e interesses dos estudantes com relação a um entendimento preciso e exato dos fenômenos explicados em sala de aula, a busca de um único significado e a ocultação de suas condições de produção. Deste modo, entendemos que tais perguntas também caracterizam fortemente os discursos produzidos em salas de aula do ensino superior de química.

A maioria das perguntas formuladas remetia à metalinguagem. A seguir são apresentados alguns exemplos de perguntas desta natureza:

Seria a mesma coisa de um imã?

O que seria o corpo negro, é uma partícula?

O que são hidrogenóides?

Mas o que é essa carga formal?

Isso não seria degeneração?

O que seria esse termo de meia-vida?

De acordo com Orlandi (1996b, p.30), a metalinguagem é um dos aspectos que caracteriza o DP como autoritário, pois "fixam-se as definições e excluem-se os fatos". Ser aluno, para esses estudantes, envolve saber definições, especialmente as que o professor sabe e deve saber. Nas perguntas apresentadas acima, verificamos a requisição de definições rígidas, o que demonstra a busca de um saber legítimo pelos alunos. Essa legitimidade, segundo Orlandi (1996b, p.31), está escorada na idéia de que há um desenvolvimento no processo escolar, paralelo ao da maturação do aluno; "enquanto ele for aluno 'alguém' resolve por ele" e as imagens que ele 
faz de si mesmo estão dominadas pela "imagem que ele deve fazer do lugar do professor", por isso, na falta de definições, ele as reivindica.

Questões relacionadas à categoria processos não foram formuladas durante as aulas observadas. Como definimos anteriormente, perguntas enquadradas nesta categoria indicam uma tendência ao discurso polêmico, pois trazem em sua formulação deslocamentos de sentidos: a visão de ciência não restrita a seus produtos finais. A ausência dessas perguntas reflete uma prática comum em aulas tradicionais, tanto do ensino superior de química como de outros níveis de ensino: formulam-se problemas, de diferentes maneiras, sem se tratar da reflexão dos fatos, nem da história das formulações dos problemas colocados pelos fatos. Segundo Orlandi (1996b, p.21), "desconhece-se a história dos conceitos, ou melhor, que os conceitos têm uma história".

\subsubsection{Nas atividades com os textos de divulgação científica}

Durante a leitura dos textos os estudantes foram requisitados a elaborarem perguntas na forma escrita. A formulação de questões não é uma atividade típica em sala de aula, não faz parte da memória dos alunos, ao formularem questões os alunos são deslocados da sua posição-sujeito, assumem um lugar que comumente pertence ao professor e, deste modo, participam da constituição de diversos objetos de conhecimento.

As questões produzidas pelos estudantes anunciaram mais objetos de conhecimento do que aqueles trabalhados em sala de aula. Além de questões que têm como objeto de conhecimento a metalinguagem, a matemática e os 
fenômenos, os alunos elaboraram questões que apresentam o processo de produção do conhecimento científico como tema. A Tabela 1 a seguir mostra as freqüências das questões, para cada categoria, em porcentagens relativas ao número total de questões formuladas pelos alunos em cada atividade.

Tabela 1 - Tipos de questões formuladas pelos estudantes na leitura dos textos.

\begin{tabular}{c|c|c|c|c}
\hline TEXTOS & $\begin{array}{c}\text { FENÔ-ME } \\
\text { NOS }\end{array}$ & $\begin{array}{c}\text { MATEMÁ- } \\
\text { TICA }\end{array}$ & $\begin{array}{c}\text { METALIN- } \\
\text { GUAGEM }\end{array}$ & $\begin{array}{c}\text { PROCES- } \\
\text { SOS }\end{array}$ \\
\hline $\begin{array}{c}\text { Capitulo 16: } \\
\text { O jardim de Mendeleiev }\end{array}$ & $14,00 \%$ & $1,00 \%$ & $34,00 \%$ & $51,00 \%$ \\
$\begin{array}{c}\text { Capitulo 24: } \\
\text { Luz brilhante }\end{array}$ & $46,34 \%$ & $3,66 \%$ & $30,49 \%$ & $19,51 \%$ \\
\hline Total & $28,57 \%$ & $2,20 \%$ & $32,42 \%$ & $36,81 \%$ \\
\hline
\end{tabular}

A Tabela 1 evidencia que, em relação a essas categorias, os textos funcionaram de diferentes maneiras, sendo algumas categorias mais presentes em um texto do que no outro. Nos tópicos a seguir apresentaremos com mais detalhes as condições de produção dessas questões.

\subsection{2a Matemática}

Esta categoria diz respeito às questões elaboradas pelos alunos que se referem à linguagem matemática. Como foi mostrado na Tabela 1, durante a leitura com os textos quase não ocorreram perguntas formuladas nessa categoria, somente três perguntas $(3,66 \%)$ para a leitura do capítulo Luz brilhante e uma pergunta $(1,00 \%)$ para a leitura do capítulo $O$ jardim de Mendeleiev. As perguntas a seguir foram formuladas durante a leitura do capitulo Luz brilhante: 
Por que quando Moseley realizou o seu experimento de bombardear os elementos químicos com raios catódicos a fim de que eles emitissem raios $X$ caracterísiticos, ele anotou o resultado em um gráfico e, no entanto, marcou os pontos de modo inverso?

Como Moseley relacionou a raiz quadrada da freqüência com o número atômico?

Quem foi Balmer? E sua fórmula qual é?

É possivel observar nas perguntas citadas anteriormente que a matemática aparece como um aspecto fundamental do trabalho de Moseley para chegar à descoberta sobre a carga nuclear. O mesmo acontece na interrogativa sobre Balmer, na qual os alunos primeiramente perguntaram de quem se tratava para depois saberem qual a lei matemática a ele associada. Na pergunta elaborada durante a leitura do capítulo O jardim de Mendeleiev, observamos uma curiosidade demonstrada pelos alunos com relação aos cálculos matemáticos que envolveram a determinação dos pesos dos elementos e como estes resultados implicavam na previsão de características de elementos ainda desconhecidos por Mendeleiev:

Através de quais cálculos era possivel prever pesos e caracteristicas dos elementos desconhecidos?

Os resultados apresentados para esta categoria indicam uma grande distinção em relação às aulas tradicionais, tanto na quantidade de perguntas elaboradas, como nos sentidos produzidos na formulação de tais perguntas. Através da leitura dos textos percebemos que o foco dos alunos foi direcionado para outros objetos de conhecimento, não ligados à linguagem matemática, e quando esta linguagem foi utilizada, percebemos deslocamentos de sentidos nos enunciados dos alunos, uma vez que indicam a matemática por eles visualizada como um resultado do trabalho científico, não reduzida a seu uso operacional. Consideramos que as perguntas apresentadas trazem traços de polissemia em sua formulação e, portanto, 
tendem a um discurso polêmico, pois tratavam as fórmulas matemáticas como partes não exclusivas de um modo de pensar, resultados de um trabalho que envolve uma série de outros aspectos.

\subsection{2b Fenômenos}

Como indica a Tabela 1, o texto que mais influenciou a formulação de questões que dizem respeito a fenômenos foi o capitulo Luz brilhante $(46,34 \%)$. Este fato pode ser justificado por diversas razões. Inicialmente é preciso notar que a atividade de leitura com o capitulo Luz brilhante trata-se da primeira leitura feita na proposta, no início do semestre letivo e, deste modo, os alunos destacaram do texto aquilo que imaginam que lhes seria cobrado posteriormente: as explicações sobre os fenômenos. É importante lembrar que, como dito anteriormente, os assuntos tratados nos capítulos estão relacionados com os conteúdos abordados em sala de aula, logo, entender esses fenômenos, na memória desses alunos, provavelmente significa conseguir explicá-los em uma avaliação. Outro fato importante a ser destacado é que, como mencionado no tópico Metodologia de Pesquisa desta dissertação, na atividade com o capitulo Luz brilhante os alunos realizaram a leitura uma única vez, em sala de aula e por um período determinado, o que talvez os tenha impedido de realizar uma leitura mais aprofundada do texto e, desta forma, produzir outros sentidos que não aqueles mais comuns em sala de aula. Em contrapartida, na atividade com o capítulo O jardim de Mendeleiev houve uma leitura prévia, conforme solicitado pelos próprios alunos, dando-lhes oportunidade de fazerem uma leitura mais cuidadosa 
sobre o capitulo. A última justificativa para estes resultados está na natureza dos textos trabalhados. No capitulo Luz brilhante são descritos os modelos utilizados por diversos cientistas em seus estudos sobre o átomo, desde o modelo de Thomson até o átomo de Rutherford, o que também pode explicar a maior ocorrência de perguntas elaboradas pelos alunos relacionadas a fenômenos, especialmente aqueles derivados dos modelos apresentados no texto.

As perguntas formuladas para esta categoria envolveram requisições de explicações sobre fenômenos com diferentes objetivos, fosse para um melhor entendimento sobre o conteúdo, ou fosse para compreenderem informações que, de algum modo, lhe chamaram a atenção durante a leitura dos textos. Questões que suscitaram saberes e interesses do cotidiano também foram formuladas.

Inicialmente destacamos as perguntas formuladas pelos alunos que requisitavam restritamente a explicação de fenômenos apresentados no texto, com o intuito de alcançarem um melhor entendimento com relação ao conteúdo:

De que maneira a "energia de ligação" influi na densidade de um metal?

Como relacionar as cores e as suscetibilidades magnéticas à camada incompleta?

Como funciona a condutividade?

O que ocorre quando há um choque de fluxo de elétrons?

Por que o mercúrio perto do zero absoluto, ao invés de se tornar um isolante, torna-se um supercondutor?

Como as cores (da luz) podem influenciar as reações químicas?

Como o "quantum" é emitido pelo elétron?

Que fundamentos da química explica o fato de alguns gases inertes poderem reagir uma vez que sua camada está completa?

Por que o magnetismo forte ilimitava os metais férricos?

Por que o manganês é um mau condutor de eletricidade quando que o ladeavam eram razoavelmente bons condutores?

Porque os metais produzem faíscas quando são raspados?

Porque a densidade dos elementos aumenta continuamente através dos periodos 4,5 e 6 e declina no periodo 7 , sendo que os elementos desse periodo são mais pesados que os do anterior?

De que forma a estrutura eletrônica dos metais explica o estado fundamental e seu caráter? 
Como o 'gás de elétrons' auxilia na condutividade dos metais?

Como os demais elementos poderiam adquirir propriedades metálicas?

Por que durante a mistura de $\mathrm{Cl}$ com $\mathrm{H}$ na presença de luz vermelha não ocorria explosão, mas na presença minima de luz branca a explosão ocorria?

Por que células fotoelétricas são ativadas por um mínimo feixe de luz azul, mas não respondiam a radiação vermelha?

Por que a reação de $\mathrm{HCl}$, quando exposta à luz branca torna-se explosiva?

As perguntas apresentadas indicam características de um discurso autoritário, pois percebemos a permanência de um sentido único, ainda que nas diferentes formas e uma reversibilidade estancada, ou seja, as perguntas dos alunos envolviam solicitações de explicações mais fechadas com relação aos fenômenos, de modo que tivessem um modelo justificado, válido, para que pudessem reproduzi-los com segurança. Notamos também na formulação desses questionamentos uma ausência de preocupação com relação às condições de produção desses acontecimentos, caracterizando mais uma vez esses discursos como autoritários, pois, segundo Orlandi (1996b), é isso que freqüentemente acontece no ambiente escolar, o DP, ao se pretender científico, pretende igualar-se a um discurso produzido em outro lugar, de onde transfere legitimidade, pois coloca as definições em primeiro plano e os fatos em segundo, como se houvesse uma só forma de dizer sobre o mundo.

É importante destacar também que em algumas das perguntas mostradas anteriormente observamos características ainda mais favoráveis à instauração de um discurso autoritário. Isso acontece porque essas questões apresentam suas respectivas respostas de maneira explícita no texto e, desta forma, não sugerem nenhum indício de deslocamento de sentidos por parte dos alunos, pois se produziram na completude do texto, ele as coloca e as 
responde, sendo a referência exclusivamente determinada pelo locutor: a verdade é imposta e já se encontra no próprio texto.

No entanto, outros tipos de questões foram formuladas. Algumas delas referiam-se a informações que os alunos solicitavam sobre algo que lhes chamou atenção no momento da leitura, como indicadas a seguir:

O que permite a enorme incandescência do sol?

Se a emissão de luz do Sol provem da fusão do elemento Hidrogênio e Hélio, principalmente, e essa fusão depende de um calor mínimo; da onde vem este calor para promover esta reação?

A energia gravitacional, que é a energia gerada por uma massa gigante ao contrair-se, mantém o Sol brilhando?

Como se sabe a temperatura do Sol por meio da sua radiação?

Como o Sol, sendo do tamanho que é, consegue se comportar como uma máquina nuclear? Como é capaz de tal organização?

Questões como estas fornecem indícios de um interesse por parte dos alunos orientado para o fantástico, baseados nas informações apresentadas no texto, em que o autor se refere ao funcionamento do Sol e às reações que ocorrem em seu interior. Observamos também questões formuladas pelos alunos que indicavam uma preocupação com relação à compreensão de fatos apresentados no texto que se revelaram curiosos e desconhecidos, conforme mostramos a seguir:

Por que os álcalis e os metais alcalinos-terrosos, exceto o magnésio, têm que ficar imersos em banhos protetores de nafta?

Por que o fósforo deve ser mantido em água?

Por que o magnésio não precisa de banho protetor de nafta?

Por que reações emitem cores diferentes? Qual é o fator capaz de dar tal caracterização?

É possivel perceber nestas perguntas a presença de mais significados que aqueles observados nos primeiros exemplos apresentados, nas quais os alunos demonstraram expectativas que vão além de explicações precisas e exatas sobre os fenômenos, mas também uma necessidade de visualizar as situações apresentadas no texto de maneira concreta e entender as suas 
condições de produção, logo, consideramos que esses questionamentos representam uma introdução à polissemia, com características favoráveis à colocação de um discurso polêmico, havendo a recuperação do objeto da reflexão, isto é, dos fatos, dos acontecimentos que, de acordo com Orlandi (1996b, p.34), “são encobertos pela fixidez do discurso autoritário”.

Como último exemplo para esta categoria, temos as perguntas elaboradas em que os alunos relacionavam os fenômenos com aspectos do seu cotidiano:

A bomba atômica e a energia nuclear baseiam-se nas reações químicas que ocorrem no interior do sol?

A lâmpada comum, utilizada em casa, também está relacionada com os niveis de energia de Planck e de que maneira?

Certos elementos não podem ser expostos na sua forma natural, pois podem causar certos malefícios, reagindo com outros elementos, como eles são encontrados na natureza sem que causem esses malefícios?

Como o UF6 separava os isótopos do urânio? Qual a utilidade disso na guerra?

Estas questões configuram um deslocamento de sentidos mais acentuado que nos outros exemplos apresentados, pois a leitura dos textos de divulgação científica proporcionou aos alunos situarem os conhecimentos científicos apresentados de forma mais abrangente. De acordo com Orlandi (1996b), no DP as informações aparecem como dadas, predeterminadas e, portanto, não sobra espaço para que se situe a articulação existente entre o discurso e o seu contexto mais amplo. Ao formularem esse tipo de questão os alunos romperam com o autoritarismo do DP, pois explicitaram o jogo dos efeitos de sentido em relação às informações colocadas nos textos dentro de seu contexto histórico-social. 


\subsection{2c Metalinguagem}

Nesta categoria são incluídas questões que dizem respeito ao significado de palavras, expressões, definições de conceitos científicos, enunciados de leis. É possivel observar, através da Tabela 1, que a formulação de perguntas de tal natureza foi freqüente para os dois textos. De acordo com Silva (2002), o trabalho com a metalinguagem faz parte da memória de um DP, da vivência escolar dos estudantes.

Os textos de divulgação científica funcionaram de diferentes maneiras na formulação de questões que remetem à metalinguagem. Perguntas que suscitavam a definição de palavras ou termos - sejam de ordem genérica ou relacionados a conteúdos científicos - foram elaboradas em abundância pelos estudantes:

O que é chamado terras-raras?

O que é um espintariscópio?

O que são metais filamentosos?

O que são os álcalis?

O que é espectroscopia?

O que é eca-tungstênio e eca-aluminio?

O que é gravidade específica? Ela varia de elemento para elemento?

O que significam os prefixos ECA, TRI e DVI de Mendeleiev?

O que é 'quintessencialmente'?

O que é 'aufbau'?

O que é luz de Sirius?

O que significa quintessencialmente e soçobrava?

O que quer dizer o adjetivo birônico?

O que quer dizer ad hoc?

O que é isqueiro Ronson e como funciona?

O que significa iridescente?

O que são nacas?

Questões como estas caracterizam claramente o DP como autoritário, nas quais observamos uma polissemia contida, não há questão sobre o objeto do discurso, apresenta-se um só caminho, segundo Orlandi (1996b), 
coloca-se o sentido único, dado e legitimado pela escola, que é a definição. É possivel, também, que alguns destes termos não sejam completamente estranhos aos alunos, mas o ambiente escolar se constitui no lugar em que eles vêem a possibilidade de confirmar ou substituir esse conhecimento por um que eles julguem mais certo, e isso é garantido pela definição.

Também foram encontradas questões formuladas pelos alunos que solicitavam explicações mais detalhadas a respeito de informações científicas contidas nos textos:

Explique sobre a regra de Hund e o Principio de Construção (aufbau)?

Em quais aspectos o tálio se assemelha com o chumbo, com a prata, com o alumínio e o potássio?

Quais eram as propriedades quimicas e físicas dos "terras-raras" que dificultavam sua distinção?

O que varia na composição do berílio, para este ser considerado ultraleve?

O urânio decai por radiação para chumbo. Qual a ordem do decaimento radioativo dos elementos?

O que seria a série numérica fundamental que baseia a tabela periódica $(2,8,8,18,18,32)$ ?

As questões expostas acima também indicam características do funcionamento de um discurso autoritário, pois percebemos em sua formulação a expectativa dos estudantes em obter respostas exatas, definições precisas e sintéticas. De acordo com Orlandi (1996b, p.19), essas formulações apresentam suas razões "em torno do referente reduzidas ao 'é porque é", isto é, definições rígidas e encadeamentos automatizados que levam a conclusões exclusivas e dirigidas.

No entanto, observamos a ocorrência de perguntas nas quais a metalinguagem se encontrava em segundo plano. Na pergunta: "Qual é a importância dos elementos artificiais?”, está representado um deslizamento de sentidos, da mera definição para o conhecimento sobre a importância desses elementos, para as implicações de sua descoberta. Isso também pode 
ser notado na pergunta: "Por que existem exceções e anomalias na tabela periódica?", a qual indica que a leitura proporcionou aos alunos uma visão de ciência com imperfeições, inacabada, diferente daquela visão de ciência pronta e sem falhas, como comumente circula na escola. Nesses exemplos notamos indícios de polissemia, pois o objeto do discurso não mais está encoberto pela metalinguagem e, portanto, não levam a um único significado.

\subsection{2d Processos}

Como já definido, esta categoria inclui questões que dizem respeito a quaisquer aspectos relacionados com a produção do conhecimento científico: formulação de hipóteses, trabalho e vida de um cientista e contexto sócio-cultural da época.

É possível notar através da Tabela 1 que o capítulo que mais engendrou a formulação de perguntas nesta categoria foi o capítulo $O$ jardim de Mendeleiev. Como citado anteriormente, consideramos que esta diferença pode ser justificada pela atividade com o capitulo Luz brilhante se tratar das primeiras leituras realizadas durante o semestre e, neste caso, acreditamos que as expectativas dos estudantes ainda se concentravam nas definições, na metalinguagem que caracteriza o DP. Um fator que já mencionamos na categoria fenômenos e consideramos também preponderante para a ocorrência de tais resultados foi a leitura prévia, sugerida aos alunos para a atividade com o capitulo $O$ jardim de Mendeleiev, que possivelmente proporcionou uma leitura mais aprofundada do texto. 
Estes resultados também podem ser justificados pela natureza do referido capítulo, no qual - assim como no capítulo Luz brilhante - são apresentadas descrições sobre modelos e teorias, no entanto, apesar de outros cientistas serem mencionados, há um destaque para um único cientista, Mendeleiev, assim como sua vida e trajetória ao elaborar a tabela periódica dos elementos químicos. Desta forma, a leitura deste capítulo pode ter impulsionado a formulação de perguntas mais diretamente relacionadas à produção do conhecimento científico.

Perguntas desta natureza não ocorreram durante as aulas tradicionais, somente na mediação dos textos de divulgação científica que, embora conduzam a este tipo de reflexão por trazerem aspectos que abordam a produção da ciência, indicam sentidos que não são comuns no DP, introduzindo a polissemia.

Observamos que os textos contribuíram de diferentes modos para configurar distintos aspectos sobre os processos de produção do conhecimento científico. A maioria das questões requeriam conhecimentos mais aprofundados sobre como se dão as pesquisas científicas, as formas de coleta de dados, os processos de medida e a obtenção de informações:

Por que foi adotado o sistema de série numérica fundamental para determinar o número de elementos? Este foi o único?

Como foi descoberto o número de prótons?

Como foram produzidos os elementos transurânicos?

Quais métodos ou principios devem ser tomados como base para a descoberta de um novo elemento?

Como é possivel relacionar medidas experimentais de massa molecular com propriedades microscópicas como a distribuição dos elétrons em camadas?

Como era determinado o peso atômico?

Como é feita uma cristalização fracionada?

Qual o processo para isolar uma substância e então obter o elemento (exceto das terras-raras)?

Como, a partir de uma separação, pode-se ter a certeza que a substância está pura? Como se obtém a massa molar de elementos não voláteis?

De que forma o composto UF6 foi usado na guerra para separar os isótopos do urânio? Qual o procedimento? 
Como os elementos das terras-raras foram separados com ajuda da espectroscopia e a cristalização fracionada?

Como são produzidos artificialmente os elementos transurânicos?

Considerando as limitações científicas da época, como os cientistas determinavam os pesos atômicos dos elementos?

Em outras perguntas os alunos demonstraram interesse em saber mais informações sobre cientistas e outros personagens mencionados nos textos que, até o momento da leitura, lhes eram desconhecidos:

Quem foi Humpry Davy? Qual a importância dele na Química?

Quem foi Dana? E Cannizzaro?

Quem foram Fagin e Svengali?

Qual a história de Jacó?

Quem foram Fagin e Svengali?

Quem foi Lecoq?

Algumas questões elaboradas pelos alunos traziam em sua formulação relações entre ações, pensamentos e atitudes com os respectivos nomes dos sujeitos, individualizados pelo discurso:

No que Mendeleiev se baseou para afirmar que os pesos atômicos de determinados elementos estavam errados?

No que Mendeleiev se apoiava para afirmar que sua tabela estava correta derrubando antigas afirmações?

Como Cannizzaro obteve confiáveis pesos atômicos?

Mendeleiev mudou pesos atômicos porque estes não se enquadravam. Como foi possível e quais os critérios utilizados para tal?

Mendeleiev sabia de quase praticamente todas as caracteristicas dos elementos que faltavam da tabela. Qual o processo de descoberta dos mesmos?

Mendeleiev se baseou em quantas e quais propriedades para elaborar a tabela periódica?

Todos os elementos seguiam à risca a regra do octeto, na qual os átomos ficariam estáveis com oito elétrons na última camada. Por que os elementos de transição não obedeciam tal regra e o que Bohr fez para resolver este problema?

Como Bohr chegou na conclusão de que os elétrons mais próximos do núcleo(mais energético) permanecia orbitando o núcleo sem emitir ou perder energia?

Qual foi o experimento de Moseley, seus resultados, conclusões. E de como chegou a tabela periódica?

De acordo com Silva (2002), a vida dos cientistas e o contexto em que eles vivem e produzem seu trabalho, configuram-se como objetos de conhecimento num movimento discursivo em que os sujeitos são nomeados e representados como pessoas reais. 
Questionamentos que dizem respeito a um contexto cultural mais amplo da produção da ciência foram elaborados com freqüência pelos alunos. Estas questões se configuram numa abordagem externalista da ciência, destacam detalhes sobre a vida, o cotidiano dos cientistas e suas relações em geral com as pessoas de sua época. A seguir, estão listados alguns aspectos da produção do conhecimento científico configurados nas perguntas dos alunos que trazem esse objeto de conhecimento em sua formulação:

i) A importância das descobertas científicas e de seus descobridores;

Quais são as importâncias da descoberta do urânio na construção da tabela periódica? De que forma Lavoisier, Prout e Dalton contribuíram para a elucidação da tabela periódica?

ii) A existência de um processo complexo na escolha, aceitação ou rejeição de idéias e teorias, e os diversos fatores envolvidos;

A tabela periódica foi aceita por todos os cientistas?

A tabela periódica criada por Mendeleiev foi aceita no mesmo ano de sua criação? Qual o tempo demandado desde a idéia inicial de Mendeleiev até a sua aceitação perante a comunidade científica, posto descrédito desta aos conceitos inovadores?

Moseley não foi questionado sobre a carga nuclear?

iii) $O$ fato de que as teorias científicas nunca estão completamente concluídas;

Houve muitas modificações na tabela periódica depois de Mendeleiev?

iv) Curiosidades sobre a comunidade científica e os acontecimentos científicos da época.

Porque houve a conferência de Karlsruhe?

Quais foram os assuntos discutidos na conferência Karlsruhe?

A elaboração de Mendeleiev decorreu das estipulações firmadas a partir da Conferência mencionada no texto ou sofreu apenas algumas modificações após esta? 
É também nesta categoria que encontramos perguntas elaboradas que apresentam os deslocamentos de sentidos mais acentuados pelos alunos, pois dizem respeito a questões que põem em dúvida a veracidade de algumas informações contidas nos textos, como podemos perceber pelas expressões: "é verdade que...?", "como ter certeza que...?" e "é possível...?"

Há elementos que não foram descobertos. Realmente é possivel existir outros elementos? Como estes se encaixariam na tabela periódica?

Em laboratório é possivel transformar um elemento não-metálico em metálico?

$\dot{E}$ verdade que tudo pode ser metalizado com altissimas pressões?

Como ter certeza de que existem apenas 92 elementos?

Nestas questões observamos indícios mais fortes de ocorrência da polissemia, tendendo ao discurso polêmico, no qual observamos a reversibilidade sob algumas condições, a procura pela simetria e a disputa da verdade pelos interlocutores. Entendemos que o exercício do questionamento faz parte de um processo de reflexão, pois, questionar um texto é trabalhar sua incompletude. Orlandi (1996b) sugere que se deve questionar os implícitos, os locutores, o conteúdo, a finalidade, o sentido dado ao ensino no DP, ou seja, questionar as condições de produção desses discursos.

\subsection{Textos produzidos pelos alunos}

Conforme mencionamos anteriormente, solicitamos aos alunos a redação de dois textos que fizessem alusão aos dois capitulos estudados nas atividades realizadas. Esses textos, de gênero livre, deveriam ser dirigidos a um leitor com as características de um calouro do curso de graduação em 
química. Estabelecemos a condição de texto de gênero livre visando dar ao aluno a possibilidade de posicionar-se livremente na produção de seu texto.

Para Maingueneau (1997), o gênero funciona como um elemento que garante a cada um a legitimidade do lugar que ocupa no processo enunciativo e a cada gênero associam-se momentos e lugares de enunciação específicos. O autor afirma ainda que os gêneros encaixam-se uns nos outros, ou seja, um mesmo texto encontra-se geralmente na intersecção de múltiplos gêneros.

$\mathrm{Na}$ análise dos textos produzidos procuramos reconhecer os processos de autoria de acordo com a distinção proposta por Orlandi (1996a) entre as repetições empírica, formal e histórica. A noção de autoria para Orlandi (1996a) e os três tipos de repetição foram apresentados no capítulo Referenciais Teóricos desta dissertação. Recordando estas definições destacamos que, para a autora, o sujeito só exerce a função-autor quando historiciza seu dizer, num jogo com a memória discursiva diretamente ligado à interpretação. Nesta situação, embora o autor se constitua pela repetição, esta é parte da história e não mero exercício mnemônico, o que configura a chamada repetição histórica. A autora distingue ainda outros dois processos de repetição que não inscrevem suas formulações no interdiscurso, não historicizam o dizer e, portanto, não promovem a autoria, são as repetições empírica e formal: na primeira o indivíduo repete exatamente da forma como leu ou ouviu, e na segunda há um exercício gramatical, no qual o indivíduo repete o que leu ou ouviu de maneira um pouco diferenciada, muda as frases, mas continua a dizer a mesma coisa apesar de usar palavras diferentes. 
$\mathrm{Na}$ análise dos textos produzidos pelos alunos procuramos identificar em que ocasiões os tipos de repetição estavam presentes. Verificamos que boa parte dos textos apresentava repetição histórica e isto ocorreu de forma variável, ou seja, em alguns textos a repetição histórica era predominante, enquanto que em outros esta repetição somente se fazia presente em alguns pontos do texto. Nos textos nos quais a ocorrência de repetição histórica era pequena ou inexistente, observamos a predominância de repetição formal. Identificamos uma pequena quantidade de textos que apresentavam repetição empírica. Vale salientar que os indícios de repetição empírica e formal foram identificados através da comparação entre os textos dos alunos e os dois capítulos estudados.

Dos 45 textos relacionados ao capítulo Luz brilhante, selecionamos nove para a análise: sete apresentavam predominantemente trechos com repetição histórica, um apresentava elementos característicos de repetição formal e outro de repetição empírica. Com relação ao capítulo $O$ jardim de Mendeleiev foram produzidos 44 textos, destes analisamos seis textos nos quais encontramos vários trechos de repetição histórica e um texto com predominância de repetição formal. Acreditamos que esta escolha representa a ocorrência dos vários tipos de repetição no conjunto total de 89 textos produzidos e que o número de textos analisados nos permite conhecer as potencialidades da leitura dos textos de divulgação científica como mediadora para a constituição do papel de autor pelos estudantes. Para Orlandi (2000), aprender a se representar como autor é assumir, diante da escola e fora dela, um papel social. Esse papel social representa a inserção do sujeito na cultura, a sua posição no contexto histórico-social. 
Cabe salientar que na apresentação da análise dos dados não distinguimos os textos relacionados aos diferentes capítulos estudados, uma vez que os aspectos abordados nesta análise se apresentaram semelhantes para ambos. Apresentamos a seguir a análise dos textos.

\subsubsection{Análise dos textos com predominância de repetição histórica}

O primeiro texto analisado trata de uma carta redigida pelo Aluno 1 (ANEXO A) a partir do capítulo Luz brilhante. Nesse texto, verificamos uma prática freqüentemente adotada em outras produções: o aluno, na posição de autor, deixou transparecer as necessidades por ele imaginadas por seus leitores - calouros de um curso de graduação em química - e tratou de atendê-las ao estabelecer um diálogo com eles através de congratulações por terem ingressado na universidade e escolhido o curso de química. Há também uma preocupação do aluno em apoiá-los com relação à escolha de tal curso, como podemos observar no Fragmento 1 a seguir:

\section{Fragmento 1}

Calouros,

Primeiramente, parabenizo muito a todos vocês pelo ingresso na Universidade de São Paulo, e mais ainda pela maravilhosa escolha pelo curso de Química!

Esta mesma intenção pode ser observada no Fragmento 2, no qual o aluno deu conselhos que julgava importantes a seus interlocutores e colocou interrogativas que imaginava serem algumas das feitas por eles ao ingressarem em um curso de graduação em química: 


\section{Fragmento 2}

Espero realmente que descubram, ou cultivem todo o encantamento pelo conjunto teórico das matérias que o curso pode oferecer. E para que vocês comecem a ter contato com a química, nada melhor do que falar sobre os elementos químicos. Como se formaram? Como foram organizados em uma tabela? Quem os organizou? Esses são alguns dos questionamentos que ao longo do curso serão solucionados; mas por que não solucionar pelo menos essas perguntas agora?

Nos Fragmentos 3 e 4, ainda com o intuito de prestar esclarecimentos a seu interlocutor, o estudante incluiu na sua produção informações que não constavam no texto original, porém relevantes para um calouro de graduação em química. Isso ocorreu quando ele deu uma breve definição sobre a ciência química, mostrou a experimentação como uma característica inerente a ela (Fragmento 3) e apresentou algumas atribuições de um químico (Fragmento 4):

\section{Fragmento 3}

Comecemos a explicar que a Química é uma ciência que nasceu da curiosidade, necessidade e ambição do homem para entender e dominar a natureza; e é a ciência que estuda as transformações que envolvem matéria e energia. Apesar de só ser reconhecida como ciência a partir do século XVIII, ela tem uma marca que sempre a caracterizou e identifica, desde seus primórdios, até os dias de hoje: a experimentação.

\section{Fragmento 4}

O objetivo de todo o químico é entender exatamente como as transformações ocorrem, conhecer os principios que regem as transformações para poder prever quando uma transformação é possivel ou não e quando sua reprodução em grande escala é viável.

Acreditamos que o uso dos recursos anteriormente apresentados esteja relacionado ao funcionamento das formações imaginárias que, segundo Pêcheux (1997), se trata de uma antecipação do que o outro vai pensar, na qual cada enunciado vem carregado da imagem que fazemos de nós mesmos e do outro. Deste modo, o sentido não existe em si, mas é 
determinado pelas posições ideológicas colocadas em jogo no processo sócio-histórico em que as palavras são produzidas. Nos fragmentos apresentados, verificamos que o Aluno 1 fez uso de uma representação imaginária de seu interlocutor para estabelecer estratégias discursivas que lhe garantissem atingir os objetivos a que se propunha ao produzir seu texto.

Observamos ainda no texto produzido pelo Aluno 1 um cuidado em direcionar seus leitores a concepções corretas com relação à produção do conhecimento científico, de modo que eles pudessem compreender a ciência como o resultado de muito trabalho, acompanhado de erros e acertos, como no Fragmento 5 a seguir:

\section{Fragmento 5}

Os princípios que iremos aprender são frutos da observação e da experimentação que o homem vem acumulando a séculos, não são verdades absolutas e acabadas. Há muito ainda que observar, experimentar e descobrir.

No Fragmento 6 também encontramos uma explicação sobre aspectos ligados à produção da ciência, no qual o Aluno 1 trouxe ao leitor a informação de que o resultado de uma pesquisa científica encoraja o nascimento de muitas outras. Além disso, neste fragmento observamos a intenção do estudante em firmar um diálogo com seu interlocutor, através da expressão "Vocês devem estar se perguntando...":

Fragmento 6

Vocês devem estar se perguntando, se tudo já estava determinado depois dessa descoberta. Se enganam os que pensaram que sim, pelo contrário, foi depois dessa descoberta que começaram a surgir os 'por quês'.

Apesar de o Aluno 1 ter apresentado em seu texto várias passagens nas quais julgamos ter havido a ocorrência de repetição histórica, não 
podemos deixar de enfatizar a grande semelhança entre vários trechos do texto produzido pelo aluno com o texto original, constituindo aspectos de repetição formal e em alguns pontos, empírica. De acordo com Santos (2006), a repetição formal define os conceitos fazendo paráfrase, repete sem incorporar qualquer idéia própria, dando um único sentido aos conceitos.

Assim como no texto produzido pelo Aluno 1, no segundo texto analisado (ANEXO B), percebemos que o Aluno 2 compôs seu discurso reunindo outras leituras que não estão no capítulo Luz brilhante, através de informações que explicavam a seu interlocutor aspectos da química considerados relevantes, como no Fragmento 7 , no qual enfatizava a importância de se tomar conhecimento da origem das descobertas químicas. Também no Fragmento 7 o estudante demonstrou claramente seu posicionamento quando explicitou sua própria curiosidade com relação ao "universo da quimica":

\section{Fragmento 7}

O universo da química é muito rico e à medida que nós aprendemos novos assuntos, de como tudo começou e foi desenvolvido, aumenta muito mais a curiosidade sobre como as coisas funcionam, ou mesmo porque acontece desse jeito.

No Fragmento 8, o diálogo do sujeito com o interlocutor também pode ser evidenciado na utilização do seguinte questionamento:

Fragmento 8

Mas, o que seria número atômico e qual sua importância?

No fragmento acima observamos também uma cautela por parte do sujeito em não restringir o termo número atômico a seu conceito, mas de aliá-lo à sua importância na compreensão de muitas propriedades dos 
elementos químicos. No Fragmento 9 encontramos a resposta para o questionamento apontado no Fragmento 8, no qual o aluno ressaltou que o conceito de número atômico pode parecer simples nos dias de hoje, uma vez que já está pronto, mas para os cientistas da época chegar até este conceito não foi tarefa fácil:

\section{Fragmento 9}

Respostas para tais perguntas parecem simples no contexto atual, mas a alguns séculos atrás essas questões eram um impasse muito grande, que fizeram do século XIX, um século de dificuldades para os químicos e físicos.

No Fragmento 10, assim como no texto anterior, o Aluno 2 demonstrou uma necessidade em abrir os olhos de seus interlocutores com relação a idéias equivocadas a respeito da produção da ciência, ao esclarecer que vários enigmas da ciência ainda estão longe de ser elucidados:

Fragmento 10

Depois de várias descobertas no mundo científico, sabe-se que essas estão longe de chegar ao fim.

Outro ponto do texto que nos chamou atenção com relação ao posicionamento do Aluno 2 como autor foi a ocorrência de uma abordagem diferenciada daquela presente no texto, na medida que optou evidenciar as relações entre os conceitos comumente tratados em situações de ensino com o cotidiano (Fragmento 11) e as conseqüências positivas dos resultados das pesquisas para a vida das pessoas (Fragmento 12).

\section{Fragmento 11}

Se pararmos para pensar em nosso dia-a-dia, retiramos milhares de curiosidades a serem saciadas, pesquisando e logo você descobrirá que não existe um mundo sem relacionar com a química, pois mesmo as coisas mais mediocres, até as mais complexas são construídas e/ou formadas a partir de átomos, formando moléculas. 


\section{Fragmento 12}

Também é impressionante como cada novas descobertas e invenções surgem para facilitar nossas vidas e ajudam, desde utilidades em casa como fontes de cura para doenças terminais, ajudando e auxiliando nosso dia-a-dia, despertando cada vez mais o espírito de pesquisar e descobrir.

No Fragmento 12 há, ainda, a idéia colocada pelo Aluno 2 de que são as aplicações em beneficio da sociedade, oriundas dos avanços científicos, as molas propulsoras para motivar os cientistas a pesquisarem ainda mais. Nos fragmentos apresentados vislumbramos a colocação de outros dizeres pelo aluno, sustentados no dizer de formulações já feitas, porém "esquecidas", indicando um domínio da sua memória discursiva (Orlandi, 1996a).

O Aluno 2, no início de seu outro texto (ANEXO C), agora relacionado ao capítulo O jardim de Mendeleiev, tece comentários a respeito da importância da leitura do capítulo em questão para auxiliar no entendimento de conceitos químicos e relacioná-los com o cotidiano (Fragmento 13). Além disso, o aluno opinou positivamente sobre o livro ("descontraido") e recomendou sua leitura a quem considera seus pares ("pessoas como nós, amantes da quimica...”).

\section{Fragmento 13}

Um texto descontraído que mostra conceitos químicos relacionados com o dia-a-dia é muito importante para facilitar o entendimento de inúmeras coisas, dentro do universo da química. Para pessoas como nós, amantes da química, é super interessante ler textos como os do livro Tio Tungstênio.

Ademais, no Fragmento 14, o aluno denotou a relação desses conteúdos com os questionamentos apresentados no capítulo, bem como a importância da união desses dois artifícios na busca de uma melhor 
compreensão a respeito da química e das conseqüências desse aprendizado para sua vida.

\section{Fragmento 14}

Juntando seus conhecimentos adquiridos em suas aulas de química estrutural, com os questionamentos feitos no livro, você poderá perceber o quão importante é o conteúdo ministrado tanto no livro e na disciplina para nossas vidas.

No texto produzido pelo Aluno 3 (ANEXO D), a partir do capítulo Luz brilhante, temos um diálogo realizado com um interlocutor, materializado na figura de um diário. Acreditamos que o uso deste tipo de destinatário reflita um texto que foi produzido para si mesmo. Este texto nos chamou atenção por vários elementos apresentados que também dizem respeito ao posicionamento do sujeito. No texto produzido, inicialmente, o aluno preferiu articulá-lo em torno das atividades desenvolvidas na disciplina (Fragmento15), o que indica a influência das situações ocorridas nas atividades na produção do mesmo. Além disso, o estudante frisou a importância da disciplina na apresentação da origem de conceitos químicos importantes ("nos mostra como tudo começou...") e as dificuldades por ele enfrentadas no decorrer das aulas da disciplina na qual a proposta foi aplicada ("apesar de ser um pouco dificil...").

\section{Fragmento 15}

Querido diário,

Hoje, dia 5 de maio de 2007, tive uma das aulas mais interessantes sobre o curso de química, da área bacharelado. Na verdade, o conteúdo faz parte de uma matéria chamada fundamentos de química estrutural, que apesar de ser um pouco dificil devido algumas coisas, mostra como tudo começou. 
No Fragmento 16, verificamos também que esse posicionamento se deu no diálogo com seu interlocutor, através da utilização de frases interrogativas e da antecipação da voz do outro ("Pois é...").

Fragmento 16

Sabia que existia um fisico londrino com bastante interesse pela química que lançou uma hipótese sobre os diferentes elementos? Pois é...

Nos fragmentos 17 e 18 encontramos o uso de questionamentos como características do diálogo estabelecido, evidenciados pelas expressões " $E$ engraçado não é?" e "Fantástico, não é?”.

Fragmento 17

É engraçado não é? Se isso acontecesse agora, nos tempos de hoje, ninguém ia aceitar como explicação algo que não está completo...

Fragmento 18

(...) foi possivel reservar um espaço, uma lacuna nessa tabela para os elementos que ainda não eram conhecidos. Fantástico, não é?

No Fragmento 17, há um contestação feita pelo aluno sobre a hipótese de um cientista ter sido sustentada como completamente correta durante um século, o que demonstra constituição de sentido, uma vez que o aluno deixa clara sua posição em relação ao assunto abordado no texto. Outro fato importante colocado pelo aluno é que, nos dias atuais, uma nova teoria leva muito mais tempo para ser aceita, e esse processo de aceitação é bem mais complexo comparado a épocas anteriores.

Uma parte do texto que também nos chamou atenção é apresentada no Fragmento 19, em que o Aluno 3 se refere a um cientista de maneira informal (um outro cara...). Isso mostra que a leitura do texto de divulgação 
lhe ajudou a conceber os cientistas como pessoas comuns, visão diferente daquela na qual os cientistas são vistos como gênios isolados. A expressão apresentada também indica que o cientista Harry Moseley, até o momento da leitura, era desconhecido ao estudante, fato que é evidenciado quando ele se refere ao cientista Rutherford como "grande" e quando inclui a expressão “esse é famoso, não é?”.

\section{Fragmento 19}

(...) em 1913 apareceu um outro cara, Harry Moseley, que também era fisico e trabalhava para o grande Rutherford (esse é famoso, não é?).

Atentamos também para o fato de que, em um momento do texto, o Aluno 3 optou pelo uso de analogias (Fragmento 20), quando comparou o estado fundamental do elétron com "sua casa" e, desta forma, buscou melhor entendimento de seu leitor.

\section{Fragmento 20}

Isso mostra que o elétron poderia saltar de um nível de energia para o outro, embora sempre retornasse à sua casa, ou seja, ao seu estado fundamental.

No Fragmento 21 percebemos que o Aluno 3 lançou mão da relação entre conceitos químicos e a vida cotidiana para ilustrar seu texto baseado no capítulo O jardim de Mendeleiev (ANEXO E).

\section{Fragmento 21}

Tem também o oxigênio, o qual é o gás essencial à nossa respiração que quando unido ao carbono formando $\mathrm{o}^{\mathrm{CO}_{2}}$ provoca o nosso temido efeito estufa.

Percebemos esta intenção quando o estudante, ao falar sobre os elementos da tabela periódica, colocou informações adicionais sobre o 
elemento oxigênio (“... gás essencial à nossa respiração...”) e sua reação com o elemento carbono que produz o dióxido de carbono $\left(\mathrm{CO}_{2}\right)$, um dos gases responsáveis pelo efeito estufa - assunto tão em voga atualmente. Percebemos também que o Aluno 3, ao falar da reação química entre o carbono e o oxigênio, utilizou conhecimentos construídos em outro lugar para complementar as informações de seu texto, que fazem parte de sua memória discursiva.

Também é digna de destaque a passagem do texto em que o aluno, em tom de ironia, fez uma crítica à forma como os conceitos químicos são comumente apresentados no ensino básico (Fragmento 22).

Fragmento 22

Sabe... Estou adorando entender todas aquelas coisas que são jogadas para nós no ensino fundamental!

A análise feita dos textos produzidos pelo Aluno 3 nos permite sugerir que o aluno se colocou na posição de autor, uma vez que fez uso de diversos recursos para promover um melhor entendimento dos assuntos contidos nos textos a seu interlocutor, além de utilizar um dos textos para tecer críticas e demonstrar insatisfação quanto à sua experiência no ensino básico de química.

Os textos produzidos pelo Aluno 4 (ANEXOS F e G), um para cada capítulo estudado, e pelo Aluno 5 (ANEXO H), baseado no capítulo O jardim de Mendeleiev, nos chamaram atenção por trazerem características do discurso poético. Nesses textos os referidos alunos lançaram mão do trabalho com a sonoridade para retratar os assuntos abordados nos capítulos. Percebemos efeitos de sentidos na própria escolha feita pelos 
alunos, pois acreditamos que tal escolha representa a tentativa do sujeito em se fazer significar.

Conforme podemos verificar nos Fragmentos 23, 24, 25 e 26; o recurso mais utilizado na produção das poesias foi o uso de analogias. No Fragmento 23, o Aluno 4 se referiu ao elemento hidrogênio como "órfão", isto porque consta no capítulo Luz brilhante que o mesmo se trata do "elemento primordial, e que todos os outros elementos teriam sido construidos a partir dele" (Sacks, 2002, p.293), daí a expressão utilizada pelo aluno “...criou do dois ao centesimal".

\section{Fragmento 23}

Mas quantos são eles?/ /São muitos? São poucos?/ E se são tantos, de onde foi que vieram?/ 'Do mais simples', disse Prout/ Que idéia genial/ Aquele pequeno órfão/ Criou do dois ao centesimal

No outro texto produzido pelo Aluno 4, no Fragmento 24, verificamos o uso de uma analogia para o conceito de valência, na qual o aluno a comparou a pétalas que as flores (elementos químicos) possuem.

Fragmento 24

Margaridas à esquerda/ Ou à direita?/ Vamos contar quantas pétalas têm!

No mesmo texto, no Fragmento 25, o aluno fez referência à informação apresentada no texto que Mendeleiev, além de ordenar os elementos químicos, também previu a existência de elementos ainda desconhecidos, quando escreveu "(...) entre violetas e orquídeas, uma planta irá nascer".

Fragmento 25

O mais importante/ É o pré-dizer/ Isso é/ Entre violetas e orquídeas/ Uma planta irá nascer 
O Aluno 5 também fez uso de analogias em seu poema (Fragmento 26) quando chamou de "primos" dois elementos de uma mesma família química. No mesmo trecho é possível observar a informação dada pelo aluno sobre o fato de o elemento situado em uma posição abaixo dentro de uma mesma família representar um elemento mais pesado.

Fragmento 26

O elemento logo abaixo,/ o pessoal tinha notado/ Se parece com o de cima/ é só um primo mais pesado

Estes exemplos evidenciam mais uma vez a intenção dos autores em tornar os assuntos científicos abordados mais próximos dos leitores, o que nos permite sugerir que os alunos, nesses momentos dos textos, historicizaram seus dizeres, uma vez que trouxeram para seu discurso outras leituras, além de incorporarem os conceitos presentes nos textos e os articularem em uma abordagem própria e inteiramente desvinculada da forma e organização do texto original.

Além de trazerem analogias com o intuito de facilitar o entendimento dos leitores com relação aos conceitos científicos tratados nos textos de divulgação científica, os textos dos Alunos 4 e 5 também abordaram aspectos do processo de construção da ciência. No Fragmento 27, o Aluno 4 justificou o fracasso do modelo atômico de Rutherford pelo fato deste não ser "Deus".

\section{Fragmento 27}

Quem criou esse não foi Deus/ foi cientista, Rutherford/ Por isso, talvez, não deu certo... 
No Fragmento 28, o Aluno 5 se referiu a Mendeleiev como o "cara da Sibéria". Como podemos perceber, a utilização deste termo indica que o aluno o considera como uma pessoa comum, a ponto de se referir a ele de maneira informal.

\section{Fragmento 28}

Como juntar estes canteiros? / Ninguém fazia idéia.../ Quem resolveu o problema/ Foi um cara da Sibéria!

O outro texto também produzido pelo Aluno 5 (ANEXO I), agora relacionado ao capítulo Luz brilhante, nos chamou atenção com relação ao posicionamento inusitado do sujeito. Em sua carta, o aluno se colocou no lugar de um dos cientistas tratados no capítulo - Niels Bohr - e produziu seu texto dirigido a um estudante de química. Verificamos neste texto uma necessidade do aluno em informar a seus leitores aspectos da produção do conhecimento científico que não são comumente tratados em sala de aula. A seguir, apresentamos alguns fragmentos do texto produzido pelo Aluno 5 . Inicialmente, apresentamos o Fragmento 29, no qual percebemos a preocupação do aluno em mostrar a que veio:

\section{Fragmento 29}

Tenho certeza de que você terá a oportunidade de aprender muita coisa sobre os átomos com seus professores e livros. Por isto mesmo eu prefiro tratar de um tema sobre o qual você vai ouvir falar muito pouco, mas que foi a base de todo o avanço na compreensão do mundo que temos hoje: eu gostaria de falar sobre a importância da criatividade para a Ciência.

No Fragmento 30, o aluno tentou situar o leitor sobre o conhecimento que se tinha na época quanto a aspectos relacionados, por exemplo, à origem dos elementos químicos: 


\section{Fragmento 30}

Quando eu era jovem como você, a ciência desconhecia muita coisa que sabemos hoje. A origem dos elementos químicos, por exemplo, era um mistério intocável. Sabíamos apenas que eles existiam e sabíamos também organizá-los numa tabela periódica conforme suas propriedades. O motivo pelo qual estas propriedades variavam periodicamente parecia estar longe de ser esclarecido.

A partir do Fragmento 31 observamos uma intenção do aluno em mostrar a seus possíveis leitores que a ciência não é produzida por cientistas isolados, mas por pessoas que trabalham em conjunto:

\section{Fragmento 31}

Foi justamente nesta época que eu tive a oportunidade de trabalhar com gente muito boa no que fazia. Um rapaz tão jovem quanto eu seu nome era Moseley - acabara de sacudir a Química demonstrando que a propriedade fundamental de um elemento era a carga do seu núcleo, e não sua massa como todo mundo acreditava.

Nos Fragmentos 32 e 33, o aluno enfatizou os problemas enfrentados pelos cientistas até o momento de aceitação de suas teorias, bem como o reconhecimento de seus feitos perante a comunidade científica:

\section{Fragmento 32}

Muita gente criticou minhas teorias quando propus que o átomo de Hidrogênio era um sistema com um núcleo e um único elétron e a radiação emitida pelo Hidrogênio excitado era conseqüência do decaimento do elétron de uma vaga de maior energia potencial para uma de menor.

\section{Fragmento 33}

Foram necessários dez anos para reconhecer o valor das minhas idéias, mas eu acabei recebendo o Nobel por elas.

Destacamos ainda, no Fragmento 34, a tentativa do aluno em dar conselhos que considera importantes a seus leitores, uma vez que se tratam de alunos que estão ingressando em um curso de química, portanto, estão 
iniciando uma trajetória que será estreitamente ligada à química e a todos os fatores a ela inerentes:

\section{Fragmento 34}

Você, estudante de Química, terá a oportunidade rara de compreender o mundo. Não se contente apenas com as respostas que a Ciência pode lhe dar: explore por si mesmo os problemas sem solução. Não existe alegria maior do que o prazer da descoberta.

A partir desta análise verificamos que a repetição histórica ocorreu ao longo de todo o texto e que o Aluno 5 se posicionou como autor diversas vezes, uma vez que demonstrou, através de seu discurso, sua idéia com relação ao que considera importante aprender em aulas de um curso de graduação em química, ou seja, a ciência não restrita a seus produtos finais. Deste modo, o aluno constituiu sentidos, colocando idéias distintas daquelas apresentadas no texto original.

O texto produzido pelo Aluno $6(\mathrm{ANEXO} \mathrm{J})$, carta redigida com base no capitulo Luz brilhante, nos chamou atenção pela forma marcante pela qual o sujeito se colocou no texto, pois assumiu uma posição crítica com relação a diversos aspectos. Inicialmente destacamos, no Fragmento 35, a desaprovação demonstrada pelo estudante referente à forma como a imagem de um químico é comumente veiculada. Esta crítica é percebida principalmente quando o estudante usou os termos “... sempre resultam em uma conclusão eficaz" - demonstrou um tom irônico e deu a entender que nem sempre as conclusões obtidas a partir dos experimentos são eficazes - e "a imagem do químico se traduz a..." - criticou o fato de a imagem do químico ser reduzida a um estereótipo. 


\section{Fragmento 35}

Escolher pela carreira de química, a principio, nos traz a idéia de um laboratório, com experimentos coloridos, nos quais saem fumaças e sempre resultam em uma conclusão eficaz. Tudo parece simples e ao mesmo tempo de grande responsabilidade. A imagem do químico se traduz a um jaleco e a um óculos de proteção.

Outra critica bastante incisiva colocada pelo Aluno 6 diz respeito às aulas por ele vivenciadas, tanto no ensino médio como nas primeiras experiências de aula no ensino superior.

Fragmento 36

(...) as primeiras aulas do curso causam um grande impacto, fazendo até com que o aluno pense que não é o curso que ele gostaria. Há mais aulas de matemática do que a própria química. O laboratório é seguido por um roteiro, no qual muitas vezes o aluno nem sabe o que está fazendo, e finalmente as aulas de química são muito complexas para quem acabou de sair de um ensino médio voltado apenas para o vestibular.

Verificamos no Fragmento 36 que o aluno demonstrou insatisfação quanto ao excesso de cálculos matemáticos trabalhados no curso de graduação, através da expressão "Há mais aulas de matemática do que a própria química", também com relação à maneira pela qual as aulas de laboratório são conduzidas, quando afirmou que "O laboratório é seguido por um roteiro, no qual muitas vezes o aluno nem sabe o que está fazendo...". O aluno também demonstrou contrariedade ao comparar a diferença de complexidade com a qual os conceitos químicos são apresentados no ensino médio (“... um ensino médio voltado apenas para o vestibular”) e no primeiro ano de graduação (“... as aulas de química são muito complexas").

No Fragmento 37, o Aluno 6 deixou transparecer sua dificuldade em relacionar os conteúdos abordados na disciplina Fundamentos de Química Estrutural com os aspectos de seu dia-a-dia, e conferiu à mesma - por 
apresentar em si fenômenos de natureza microscópica - a justificativa para o fato de não conseguir abstrair os conceitos a ela relacionados.

\section{Fragmento 37}

As aulas referentes à disciplina Fundamentos de Quimica Estrutural são as mais intrigantes, pois pertencem à estrutura microscópica, ou seja, não é possivel, a princípio, empregar o conteúdo no dia-a-dia, tornando assim de difícil visualização e portanto de difícil entendimento.

No texto produzido pelo Aluno 6, consideramos que o efeito de sentidos é claro, uma vez que o sujeito se mostrou presente, ele utilizou o texto para colocar opiniões próprias e demonstrar a sua não-concordância com os modos pelos quais o processo de ensino-aprendizagem tem sido configurado em seu meio, tanto no ensino médio, como na graduação. Acreditamos também que o aluno lançou mão de seu texto para demonstrar suas dificuldades no entendimento dos conceitos ligados à disciplina e julgou, talvez, que o professor poderia ler seu texto.

No texto produzido pelo Aluno 7 (ANEXO K), referente ao capítulo $O$ jardim de Mendeleiev, verificamos que o aluno trouxe, inicialmente, informações a seu interlocutor sobre a importância da química e da sua forte presença na vida humana (Fragmento 38). O aluno, neste fragmento, faz uso de intercalação, pois ao complementar seu discurso, visou um melhor entendimento do seu leitor.

\section{Fragmento 38}

A Química está muito mais presente no nosso dia-a-dia do que imaginamos. Desde as reações químicas que acontecem no nosso corpo (por exemplo o ar que respiramos nas células), a todas as outras coisas que acontecem ao nosso redor (por exemplo, o simples fato de abrir um refrigerante, ou até mesmo a água e a comida que nos sustentam) e também aquelas mais sofisticadas, como por exemplo a manipulação de um novo fármaco ou o lançamento de um iogurte. 
No Fragmento 39, assim como em outras produções, o aluno também achou considerável dar informações a seus leitores sobre as valiosas contribuições do trabalho científico para o alcance dos resultados conhecidos atualmente e do tempo demandado para essas pesquisas.

Fragmento 39

Para isso, muitos cientistas, químicos e físicos, tiveram que gastar longas horas em seus experimentos para chegar no que conhecemos...

O Aluno 7 também lançou mão de analogias na produção de seu texto (Fragmento 40). Isto pode ser observado quando o aluno se referiu à Tabela Periódica dos Elementos Químicos como uma "lista telefônica", na qual é encontrado "o endereço" de cada elemento químico.

Fragmento 40

Esta tão poderosa arma dos cientistas é como se fosse nossa lista telefônica. Nela encontramos o 'endereço' de cada elemento químico.

No Fragmento 41, o aluno colocou em foco a grande responsabilidade de um pesquisador ao desenvolver novos produtos, bem como seus aspectos éticos, e tentou fazer com que seus leitores tomassem conhecimento do poder que um cientista tem em mãos e das conseqüências para a humanidade. O Aluno 7 se colocou claramente na posição de autor, uma vez que deixou clara a sua posição com relação às questões éticas na ciência, esta posição pode ser observada quando utilizou a palavra "infelizmente" no Fragmento 41 e quando demonstrou seu desejo particular, através da expressão "Esperamos que..." (Fragmento 42). 


\section{Fragmento 41}

Sabendo tudo isso, os químicos podem ajudar em muito (ou até mesmo prejudicar) a humanidade. Podem descobrir qual substância seria eficaz ao combate da AIDS e assim compor um novo remédio, descobrir qual substância que é mais resistente a um material ou até mesmo (infelizmente) manipular um veneno.

\section{Fragmento 42}

Esperamos que o Homem use todas essas poderosas ferramentas apenas para ajudar a si próprios e esquecer todo o mal que pode causar.

No texto produzido pelo Aluno 8 (ANEXO L), a partir do capítulo Luz brilhante, mostramos uma prática utilizada por alguns alunos na produção de seus textos: a presença de conceitos colocados pelo aluno que não estão vislumbrados no texto original, portanto, constituem uma repetição histórica. No entanto, esta repetição ocorreu de forma distinta daquela empregada nos textos anteriormente analisados, pois o aluno inseriu conceitos trabalhados em sala de aula, sem produzir sentidos que não aqueles comumente presentes em ambientes de ensino. No Fragmento 43, podemos perceber que o Aluno 8 trouxe para seu texto informações adicionais àquelas apresentadas no capítulo, porém não demonstrou seu posicionamento e nem procurou modificar a linguagem rigida expressa nesses conceitos.

Fragmento 43

O efeito fotoelétrico consiste na emissão de elétrons de uma superficie metálica pela incidência de ondas eletromagnéticas sobre essa superficie.

É possível observar que o aluno, ao utilizar a intercalação, buscou melhor entendimento de seu interlocutor, entretanto, usou uma definição 
fixa para "qualquer objeto que tivesse energia", como se esta fosse a única possivel (Fragmento 44).

\section{Fragmento 44}

Um corpo negro é um objeto que emite toda energia que nele é incidida. A física de Planck não explicava essa emissão porque segundo as leis vigentes qualquer objeto que tivesse energia (ou seja, corpos que não estão a $\mathrm{OK}$ ) deveriam emitir radiação ultravioleta.

No Fragmento 45, temos outro aspecto que caracteriza fortemente o discurso apresentado pelo aluno como um discurso típico de sala de aula: o uso de fórmulas matemáticas. Isto pode ser verificado em várias passagens do texto.

\section{Fragmento 45}

Então se a energia $\mathrm{E}$ é fornecida por aquecimento a um corpo negro, o mesmo deve emitir uma onda de freqüência $\mathrm{E} / \mathrm{h}$, pois a maioria dos átomos de um corpo negro teria agora uma energia maior $\mathrm{E}$.

Mesmo com predominância de um sentido único, o texto produzido pelo Aluno 8 apresenta deslocamentos de sentidos. Esses deslocamentos podem ser visualizados através de exemplos citados pelo estudante, decorrentes da aplicação das teorias contidas em seu texto (Fragmentos 46 e 47).

\section{Fragmento 46}

Esse resultado é utilizado em células fotoelétricas para automação de sistemas dependentes da luz do dia, como postes, controles-remoto e até mesmo para a geração de energia elétrica por meio de raios solares.

\section{Fragmento 47}

Assim, cada sal de metal emite uma cor ao ser aquecido e este fato é utilizado, por exemplo nos fogos de artifício, que não são nada menos do que pólvora com sais de diferentes metais. Quando a pólvora queima, libera energia suficiente para possibilitar o salto dos elétrons nos átomos dos metais, proporcionando-nos assim um verdadeiro espetáculo quântico. 
De modo semelhante ao texto do Aluno 8, no texto produzido pelo Aluno 9 (ANEXO M), referente ao capítulo $O$ jardim de Mendeleiev, observamos a tentativa de complementação dos conceitos apresentados no texto original por aqueles tratados em sala de aula. Porém, no texto produzido pelo Aluno 8, não observamos nenhuma indicação de diálogo entre o sujeito e seu interlocutor, já no texto produzido pelo Aluno 9 esse diálogo é percebido no discurso, no qual ele iniciou seu texto felicitando seu "colega" pelo ingresso na universidade (Fragmento 48). O posicionamento do Aluno 9 também pode ser vislumbrado quando ele colocou sua opinião em relação à universidade na qual estuda (“... uma das maiores universidades do Brasil") e decidiu dar conselhos que considera importantes a seu interlocutor.

Fragmento 48

Caro colega,

Queria felicitá-lo pelo ingresso em uma das maiores universidades do Brasil. Pode parecer estranho o que vou te dizer, mas é a verdade que deve guiar seus pensamentos. Entrar é a parte mais fácil, dificil é conseguir acompanhar o ritmo de estudos impresso, principalmente no primeiro semestre. É esse momento que muitos desistem, porém é essencial ter garra e fé que tudo pode ser melhorado.

5.2.2 Análise dos textos com predominância de repetição formal

No texto produzido pelo Aluno 10 (ANEXO N), com base no capítulo Luz brilhante, verificamos a utilização do exercício gramatical. Embora tenhamos observado - em alguns momentos do texto - a tentativa do aluno em historicizar, em não reproduzir literalmente o texto original, a repetição formal foi predominante na produção de seu texto, o que não indica, 
portanto, um ato interpretativo, pois, segundo Orlandi (1996a, p.67), “a interpretação não é mero gesto de decodificação, de apreensão do sentido". Para efeito de comparação, apresentamos o primeiro parágrafo do texto do aluno e os dois primeiros parágrafos do texto original.

\author{
Primeiro parágrafo do texto produzido pelo Aluno 10
}

Em 1815, cerca de cinqüenta elementos eram conhecidos e segundo Dalton isso implicaria em cinqüenta tipos diferentes de átomos. Especulava-se que o hidrogênio era o elemento primordial e que todos os outros foram construídos a partir dele, pois William Prout, físico com interesse em química, observou que os pesos atômicos eram múltiplos do peso atômico do hidrogênio. No entanto, alguns elementos apresentaram pesos atômicos fracionários e só podia-se arredondar os pesos que fossem ligeiramente menor ou maior que um número inteiro. Isso dificultou a idéia de Prout, e essa dificuldade só aumentou quando Mendeleiev elaborou a tabela periódica; elementos, no aspecto químico, vinham antes e, no peso atômico vinham depois. Apesar desses grandes obstáculos, a hipótese de Prout nunca foi esquecida e mais adiante veremos que foi comprovada.

\title{
Primeiro e segundo parágrafo do capítulo Luz brilhante
}

(SACKS, 2002, p.293)

De quantos elementos Deus precisaria para construir um universo? Cinqüenta e poucos elementos eram conhecidos em 1815; e, se Dalton estivesse correto, isso significaria cinqüenta tipos diferentes de átomos. Mas com certeza Deus não precisaria de cinqüenta unidades constitutivas diferentes para Seu universo - sem dúvida ele o teria concebido mais economicamente que isso. William Prout, um físico londrino com interesse pela química, observando que os pesos atômicos era próximos de números inteiros e, portanto, múltiplos do peso atômico do hidrogênio, especulou que o hidrogênio seria, de fato, o elemento primordial, e que todos os outros elementos teriam sido construidos a partir dele. Portanto, Deus precisaria criar apenas um tipo de átomo, e todos os demais, por uma 'condensação' natural, poderiam ter sido gerados a partir deste.

Acontece, infelizmente, que alguns elementos tinham pesos atômicos fracionários. Podia-se arredondar um peso que fosse ligeiramente menor ou maior que um número inteiro (como fez Dalton), mas o que fazer com o cloro, por exemplo, de peso atômico 35,5? Isso dificultou sustentar a hipótese de Prout, e surgiram dificuldades adicionais quando Mendeleiev elaborou a tabela periódica. Ficou claro, por exemplo, que o telúrio vinha antes do iodo, mas seu peso atômico, ao invés de menor, era maior. Essas eram dificuldades sérias, e no entanto, por todo o século XIX, a hipótese de Prout nunca morreu realmente - era tão bela, tão simples, julgavam muitos químicos e físicos, que devia ter uma verdade essencial. 
No texto produzido pelo Aluno 11 (ANEXO O), com base no capítulo $O$ jardim de Mendeleiev, observamos traços de autoria, quando o aluno se direcionou a seus interlocutores por meio de uma frase interrogativa ("Já teve a oportunidade de ver quão diferentes e fascinantes são os elementos, mesmo que seja só na aparência?") e pela antecipação ao outro ("Se não, não sabe o que está perdendo como químico"). No entanto, este tipo de manifestação só ocorre no início do texto. No restante do texto verificamos a presença de seleção de trechos do texto original, em alguns casos dispostos de maneira desconexa e apresentando informações erradas, quando o autor do texto original se refere ao desenvolvimento do termo valência ter ocorrido "no final da década de 1850...", e o aluno ter afirmado que o referido termo foi desenvolvido exatamente em 1850. A seguir, como exemplo, apresentamos o segundo e terceiro parágrafo do texto produzido pelo Aluno 11, e, em seguida, o sexto (parte) e o sétimo parágrafo do texto original:

Segundo e terceiro parágrafo do texto produzido pelo Aluno 11

Definiremos, neste texto, algumas propriedades da tabela periódica e como foram desenvolvidas. A principio, deve ser salientado a importância da valência, termo definido adequadamente em 1850, apresentando para valência, um caráter racional, uma base para que eles possam formar famílias e servir como base para analogias químicas e físicas.

A valência segue em ordem crescente acompanhando seu grupo (valência 1 no grupo I => valência 8 no grupo VIII)

Sexto (parte) e sétimo parágrafo do capítulo O jardim de Mendeleiev (SACKS, 2002, p.192)

(...) O termo valência não aparecia em meus livros vitorianos mais antigos, pois só fora desenvolvido adequadamente no final da década de 1850; Mendeleiev foi um dos primeiros a aproveitá-lo e usá-lo como base para classificação, a apresentar o que nunca antes estivera claro: um fundamento racional, uma base para o fato de os 
elementos parecerem formar famílias naturais, terem profundas analogias químicas e fisicas uns com os outros. Mendeleiev então reconheceu oito desse grupos de elementos segundo suas valências.

Assim, os elementos do Grupo I, os metais alcalinos, tinham valência 1: um átomo desses elementos combinava-se a um átomo de hidrogênio, formando compostos como $\mathrm{LiH}, \mathrm{NaH}, \mathrm{KH}$ etc. (Ou com um átomo de cloro, formando compostos como $\mathrm{LiCl}, \mathrm{NaCl}, \mathrm{KCl}$.) Os elementos do Grupo II, metais alcalino-terrrosos, tinham valência 2, formando compostos como $\mathrm{CaCl}_{2}, \mathrm{SrCl}_{2}, \mathrm{BaCl}_{2}$ etc. A maior valência, 8, pertencia aos elementos do Grupo VIII.

5.2.3 Considerações sobre os textos com predominância de repetição empírica

Com relação aos textos que apresentaram o recurso da repetição empírica, identificamos manifestações de um tipo de aprendizado que é conduzido via repetição mnemônica. Percebemos, em alguns textos produzidos pelos sujeitos de nossa pesquisa, que houve o uso explícito de longos fragmentos apresentados nos textos originais. Em alguns casos, a tarefa limitou-se a uma cópia de vários parágrafos dos capítulos originais. Segundo Orlandi (2000), no contexto escolar, esse tipo de repetição ocorre quando o aluno repete o que o professor transmite, sem buscar o seu entendimento. Como exemplo, apresentamos a seguir trechos de um texto produzido pelo Aluno 12 (ANEXO P), com base no capitulo Luz brilhante, e em seguida um trecho do terceiro parágrafo do texto original:

Segundo parágrafo do texto apresentado pelo Aluno 12

Em 1913, Harry Moseley começou a investigar átomos com a recém desenvolvida técnica da espectroscopia de raios X, onde Moseley bombardeava cada elemento, no vácuo, com raios catódicos, fazendo com que emitissem raios $\mathrm{X}$ característicos. Moseley fez um gráfico das raizes quadradas das freqüências em relação ao número atômico, e obteve uma reta. Ao marcar inversamente os pontos, ele demonstrou que o aumento na freqüência indicava passos nitidos e discretos, ou saltos quando passava ao elemento seguinte. Moseley julgou que isto era uma propriedade atômica fundamental, e esta só poderia ser a carga nuclear. 
Trecho do terceiro parágrafo do capítulo Luz brilhante (SACKS, 2002, p.294)

\begin{abstract}
Haveria, talvez, alguma propriedade atômica que fosse mais integral, mais fundamental que o peso atômico? Esta não era uma questão que pudesse ser abordada antes de haver um modo de 'sondar' o átomo, em especial sua porção central, o núcleo. Em 1913, um século depois de Prout, Harry Moseley, jovem e brilhante fisico que trabalhava com Rutherford, começou a investigar átomos com a recém-desenvolvida técnica da espectroscopia de raios $\mathrm{X}$. Sua aparelhagem experimental era encantadora e pueril:um trenzinho onde cada vagão transportava um elemento diferente passava por um tubo de vácuo de noventa centímetros de comprimento, onde Moseley bombardeava cada elemento com raios catódicos, fazendo com que emitissem raios X característicos. Quando Moseley marcou em um gráfico as raizes quadradas das freqüências em relação ao número atômico dos elementos, obteve uma reta; marcando os pontos de modo inverso, ele demonstrou que o aumento na freqüência indicava passos nítidos e discretos ou saltos quando ele passava de um elemento ao seguinte. Isso tinha de refletir uma propriedade atômica fundamental, julgou Moseley, e essa propriedade só podia ser a carga nuclear.
\end{abstract}

Acreditamos que a ocorrência de repetição empírica nos textos produzidos esteja ligada a certo receio por parte dos alunos em explicitar sua interpretação e, de algum modo, apresentar conceitos e/ou idéias equivocadas a respeito de assuntos apresentados nos textos estudados. Desta forma, os alunos que optaram por usar este tipo de repetição, preferiram reproduzir os conceitos apresentados no texto que, em seu imaginário, provavelmente estão corretos. Consideramos também que nesses casos ocorre o apagamento da real função dos textos de divulgação científica, em que os alunos lançaram mão deste material tal como costumam fazer com o livro didático, ou seja, segundo Orlandi (1996b, p.22), na escola o material didático anula sua condição de mediador: o que interessa "não é saber utilizar o material didático para algo", e sim, "saber o material didático". 
Outra justificativa para tal fato está na atribuição de nota dada à produção dos textos. Embora não soubessem o quanto esta tarefa representaria em suas notas finais, os alunos elegeram fazer uso das idéias apresentadas nos textos para garantirem uma boa nota, do que se arriscarem em colocar conceitos que não sabiam se estavam completamente certos. Para Santos (2006), esse tipo de reprodução demonstra o receio do aluno em assumir seu próprio discurso, conseqüência da imagem que o aluno faz da imagem que o professor faz do próprio aluno.

5.3 Percepções dos alunos sobre a proposta de ensino aplicada

No início do semestre de aplicação da proposta, solicitamos aos alunos que fizessem uma leitura dos capitulos iniciais do livro e respondessem a um questionário a respeito das impressões iniciais com relação ao texto (APÊNDICE C). Ao final dos dois encontros com os textos de divulgação científica, também foi solicitado aos estudantes que comentassem sobre suas percepções com relação às atividades realizadas (APÊNDICES D e E). Vale lembrar que o questionário referente à segunda atividade diferia do primeiro por apresentar mais uma questão, na qual era requisitado aos alunos que fizessem comparações entre as duas atividades. Foi solicitado ainda, no final do período letivo, que os alunos respondessem a um questionário sobre as habilidades que acreditavam ter desenvolvido ou aperfeiçoado durante o período no qual trabalhamos com os textos, bem como informações a respeito da proposta como um todo (APÊNDICE G). 
Analisamos os questionários e apresentamos a seguir as considerações a respeito das respostas dadas pelos estudantes para as questões formuladas.

5.3. 1 Impressões iniciais dos alunos com relação à leitura do livro

Com relação às impressões dos estudantes sobre a leitura do texto, percebemos que a maioria deles apresentou opiniões positivas a respeito, embora tenham expressado esse sentimento com diferentes graus de entusiasmo. Encontramos muitas referências à leitura como "agradável” e de "fácil entendimento", alguns alunos a consideraram "curiosa" e "envolvente" e existiram, ainda, considerações nas quais alguns alunos se referiram à linguagem apresentada no livro, como da seguinte forma: "É um texto muito interessante capaz de passar algum conhecimento para pessoas sem muita formação quimica". A seguir apresentamos um trecho de um dos depoimentos apresentados que bem representa a opinião dos alunos em relação à leitura do livro:

"É um texto de leitura leve e fácil, mas interessante por retratar como uma criança percebia fatos relacionados à Química no seu cotidiano..."

Em alguns poucos casos os alunos expressaram posicionamentos negativos com relação à leitura do texto. Tal fato aconteceu quando se referiram à mesma como "cansativa" e "entediante", ou usaram termos afins.

Em resposta ao questionamento sobre as relações que poderiam ser estabelecidas entre os assuntos abordados no texto e os conhecimentos adquiridos durante as aulas ou no dia-a-dia, verificamos um consenso entre 
os estudantes no que diz respeito à ocorrência dessa relação no texto.

Algumas das justificativas apresentadas pelos estudantes são as seguintes:

"É possivel estabelecer relações entre o que foi dito no livro com meus conhecimentos do dia-a-dia e na época do colegial. Como por exemplo, no laboratório da escola, eu aprendia a diferença de densidade das substâncias, o ponto de fusão e ebulição das misturas. No dia-a-dia, a curiosidade em saber como funciona as coisas são equivalentes a do autor."

"Sim. Logo nas primeiras passagens do texto o autor descreve vários metais e os diferencia através de suas propriedades fisico-quimicas: seu brilho, sua uniformidade, maleabilidade, densidade, resistência à corrosão. O autor cita ainda os conhecimentos que obteve na infância sobre a composição de ligas metálicas.”

Constatamos também que nenhum dos alunos havia lido o livro em pauta ou alguma das outras obras de Oliver Sacks, assim como este também não era conhecido por nenhum deles. Alguns alunos declararam somente terem ouvido algo a respeito do referido livro e nos chamou atenção a declaração de um deles, que afirmou ter tomado conhecimento do livro através da recomendação de um de seus professores:

"O autor, para mim, era desconhecido; no entanto, já ouvi falar do livro Tio Tungstênio quando um professor de física o recomendou como leitura essencial para o despertar da investigação científica."

As respostas dadas ao referido questionário nos permitem sugerir que a primeira aproximação dos estudantes com o texto se deu de maneira satisfatória, uma vez que consideraram a leitura do texto agradável e de fácil entendimento, assim como conseguiram relacionar os assuntos tratados no texto com os conhecimentos adquiridos em outras situações. 


\subsubsection{Impressões dos alunos a respeito da primeira atividade}

O segundo questionário diz respeito às impressões dos estudantes referentes à atividade com o capítulo Luz brilhante. Os pronunciamentos dos estudantes - no que diz respeito à relação entre assuntos apresentados nas aulas teóricas e aspectos contidos no texto - foram colocados, via de regra, com as seguintes palavras:

"Vários aspectos do texto têm relação com os assuntos das aulas, por exemplo, as explicações sobre energia, as teorias dos cientistas, sobre a estrutura do átomo e como estes se comportam em determinadas situações etc."

"Grande parte dos assuntos tem relação direta com matérias da aula teórica, como os modelos atômicos, comportamento dos elétrons etc."

Nos depoimentos a seguir, percebemos o entendimento por parte de alguns estudantes com relação a uma das funções do texto: complementar os conteúdos tratados no livro didático e nas aulas teóricas.

\footnotetext{
"Ele abrange a matéria de uma forma mais 'leve', o texto tem total relação com as aulas de Fundamentos de Quimica Estrutural, só que não aprofunda tanto como nas aulas".

"O texto apresenta de uma maneira simplificada os conhecimentos apontados no Mahan, de certa forma é mais fácil ler a história do que tentar pesquisar no Mahan, o único inconveniente é a falta de aprofundamento dos conhecimentos".
}

Verificamos também que a maioria dos alunos considera que a leitura do texto contribuiu de alguma forma para melhor compreenderem os assuntos abordados em sala de aula. As justificadas mostradas a seguir ilustram de maneira representativa as opiniões dos estudantes em relação a tal afirmativa:

\footnotetext{
"Sim, o texto está explicando teorias de uma maneira menos rebuscada, fazendo analogias com o dia-a-dia, promovendo assim um melhor entendimento".
} 
"Com certeza. Com a leitura do texto reforcei meu conhecimento sobre o que tinha aprendido e entendi melhor as partes em que tive algumas dúvidas".

"Sim, pois o texto apesar de tratar do mesmo assunto, o apresenta com uma linguagem e uma visão diferente dos livros mais teóricos como o Mahan. Isso facilita a compreensão e entendimento da matéria proposta em sala de aula".

"Com certeza, o texto é mais dinâmico e mostra uma forma mais fácil de entendimento, mais resumida, sem muitas fórmulas".

Tais respostas indicam que a leitura do capitulo permitiu aos estudantes reforçar e confirmar os conhecimentos adquiridos nas aulas teóricas e, através de sua linguagem informal, apresentou os conceitos de maneira mais compreensivel a eles.

A última pergunta lançada aos estudantes dizia respeito a suas opiniões em relação à atividade realizada. Tais opiniões foram, em concordância geral, favoráveis à atividade, no entanto, também foi quase unânime a insatisfação dos alunos com relação ao tempo estipulado para a leitura do capítulo. Os pronunciamentos a seguir ilustram bem esses posicionamentos:

\footnotetext{
"Gostei da atividade, mas achei que faltou um pouco de tempo..."

"Fez com que abordássemos o assunto de uma forma diferente. O único desconforto foi o tempo limitado, que poderia ter sido contornado se o texto tivesse sido dado antes da atividade".

"Acredito que a atividade foi bastante construtiva, importante para desenvolver e discutir os assuntos abordados nas aulas teóricas, mas o tempo para realizar as tarefas é muito curto. Portanto, se tivéssemos lido o texto antes da aula, o rendimento poderia ter sido melhor".
}

O referido questionário se mostrou de grande valia ao nos permitir colher sugestões para a melhoria da proposta ainda no período de aplicação. Deste modo, acatamos as solicitações dos alunos com relação à necessidade 
de um intervalo maior para a leitura dos textos e propusemos que a leitura do segundo capítulo fosse realizada antecipadamente.

\subsubsection{Impressões dos alunos a respeito da segunda atividade}

O terceiro questionário diz respeito às impressões dos estudantes referentes à atividade com o capítulo $O$ jardim de Mendeleiev. Tais impressões se assemelham àquelas demonstradas pelos alunos com relação à primeira atividade no que diz respeito às associações feitas por eles entre os conteúdos tratados em sala de aula e aqueles abordados no texto, e às contribuições para melhor entendimento em relação às aulas teóricas. No questionamento referente às suas opiniões sobre a atividade realizada, verificamos grande distinção, uma vez que a maioria dos alunos considerou a segunda atividade mais proveitosa que a primeira. As duas justificativas mais freqüentemente citadas estão relacionadas com a leitura prévia feita por eles do capítulo a ser estudado e com o fato de estarem mais familiarizados com o esquema da atividade.

\footnotetext{
"As atividades do segundo trabalho foram mais proveitosas, pois já estávamos familiarizados com o esquema da aula".

"Ambas foram boas, mas essa última foi melhor por nos propiciar mais tempo".

"A segunda atividade foi mais interessante pois o texto era mais fácil que o anterior".
}

Acreditamos que essa "facilidade" percebida por alguns alunos no segundo capítulo esteja relacionada ao fato, que já mencionamos, de ter havido uma leitura prévia do texto, o que permitiu uma leitura mais 
aprofundada ou até mesmo uma releitura deste e, portanto, favoreceu um melhor entendimento a respeito de seu conteúdo.

5.3.4 Impressões dos alunos com relação ao processo de aplicação da proposta

O questionário que aplicamos no final do semestre letivo englobava uma série de questões pertinentes à proposta aplicada. Inicialmente perguntamos aos alunos se já haviam tido alguma experiência em sala de aula envolvendo a leitura de textos de divulgação científica. A maioria dos alunos afirmou não ter tido nenhuma experiência desta natureza, quanto aos que declararam o contrário, obtivemos os seguintes comentários:

"Já havia lido texto em revistas devido a trabalhos do colégio e para o vestibular. Mas nenhum foi trabalhado com esse do Tio Tungstênio".

"A leitura de textos de divulgação científica ocorreu algumas poucas vezes durante o decorrer do ensino básico. Geralmente o professor condutor da tarefa distribuía revistas de divulgação científica mais abrangentes como Superinteressante, Mundo Estranho e pedia relatórios e resumos de cada grupo e portanto de cada artigo que o grupo havia escolhido. Era uma maneira interessante de fazer os alunos aprenderem sem a monotonia da 'matéria da lousa'".

Em contrapartida, quando perguntamos aos alunos se alguma vez fizeram a leitura de algum texto de divulgação científica sem a solicitação de um professor, verificamos que a grande maioria deles afirmou que sim e em seus depoimentos, de um modo geral, percebemos a satisfação deles em fazê-la. Os principais critérios apontados pelos estudantes para a escolha deste tipo de leitura residia no fato de apresentarem uma linguagem simples e ausência de fórmulas matemáticas. Os pronunciamentos a seguir ilustram as opiniões dos estudantes a esse respeito: 
"Sim. De modo geral, minha afinidade pela leitura vincula-se a textos científicos (...) textos que tratam de quimica ou estudos sobre inovações tecnológicas. As publicações da revista Galileu exemplificam isso".

"Sim, eu já havia lido. O que eu levei em consideração foi a facilidade no entendimento (linguagem não técnica) e pouca matemática. Por exemplo, o texto de divulgação científica que mais gostei foi uma edição da Scientific American que fala sobre os gênios quânticos da ciência...”

De fato, como afirmam Terrazzan e Gabana (2003), os textos de divulgação científica apresentam os assuntos numa linguagem flexível e próxima da utilizada no cotidiano das pessoas, não costumam exagerar no aprofundamento em detalhes específicos nem no uso de simbologia matemática como costuma acontecer em livros didáticos.

Observamos quase a existência de um consenso nas impressões dos alunos com relação aos conteúdos e à forma como estes foram apresentados pelos autor nos capítulos estudados. Eles expressaram satisfação ao falarem sobre as leituras realizadas, como nos comentários a seguir:

"Tio Tungstênio é incrivel. Adorei a forma como o autor leva a história de sua vida à ciência (...) o capitulo Luz brilhante é meu preferido entre os que li. $O$ autor fala de maneira leve e que foge um pouco do "peso da química"..."

“... pode-se dizer que a forma como o autor descreve todo seu fascinio e conhecimento, facilita muito o entendimento do assunto, que não é dos mais fáceis de ler, porém a empolgação do autor em suas descrições, encoraja o leitor a se aprofundar no assunto."

"O conteúdo foi apresentado de maneira a nem percebermos que estamos nos deparando com conceitos quimicos, pois todos os capitulos contaram o dia-a-dia, a vida de um menino na qual a quimica se fazia presente."

"A forma com que eles foram apresentados pelo autor é muito agradável. No decorrer de seus textos, ele provoca aos leitores muita curiosidade, faz com que desenvolvamos nosso raciocínio seguindo sua linha de pensamento."

Do mesmo modo, percebemos uma grande concordância entre os alunos no que diz respeito à relevância da leitura dos textos para o 
aprendizado na disciplina. Constatamos que esta relevância se deu de diferentes formas para os alunos, desde a eliminação de dúvidas até a visualização do conteúdo de forma mais contextualizada:

\begin{abstract}
"Sim, uma vez que o livro aborda os conteúdos da disciplina de maneira simples, facilitando a assimilação e favorecendo o entendimento".

"A leitura destes capitulos auxiliou a compreensão do que foi visto em sala de aula porque eu, particularmente, gosto de relacionar os personagens e suas teorias com o momento histórico em que viveram. Isso auxilia na compreensão do que está sendo estudado pois mostra o porque disto ter acontecido".

"O conteúdo apresentado certamente ajudou no entendimento da disciplina, pois foi exposto de uma forma menos complexa do que os livros normalmente utilizados..."

"Esses capitulos me ajudaram a simplificar o entendimento de partes da matéria do professor que me causavam certas dificuldades, esses textos acabaram sendo mais simples e diretos através de uma abordagem diferente da do professor, uma segunda visão do assunto, de forma mais elementar porém necessária para quem não tem a devida "base" no assunto".
\end{abstract}

A seguir temos alguns exemplos específicos dados pelos alunos de situações nas quais a leitura dos textos foi de grande importância para uma melhor compreensão dos conceitos abordados em sala de aula:

"Consegui entender melhor o significado da expressão "aufbau" e as questões relacionadas à tabela periódica e suas propriedades”.

"Um exemplo que pode ser mencionado, pois me ajudou muito na compreensão da matéria foi quando foi explicado o átomo de Bohr e seu equivoco".

"Um exemplo bem específico foi quando o professor explicou a matéria de propriedades periódicas e logo em seguida fizemos a atividade do livro Jardim de Mendeleiev, onde também conhecemos muitas propriedades dos elementos já estudados".

"As teorias e modelos atômicos de Rutherford e Bohr, por exemplo, aprendidos na aula, tornaram-se bem mais claros após a leitura dos textos..."

Para Ferrari, Angotti e Cruz (2005), os textos de divulgação científica, apesar de não terem sido produzidos com este objetivo, podem se tornar um 
material paradidático no ensino formal, auxiliando no esclarecimento de conceitos científicos.

Observamos também uma grande aceitação por parte dos alunos com relação ao processo de realização das atividades. As sugestões apresentadas por eles foram variadas, dentre estas, encontramos principalmente solicitações relacionadas à incorporação da atividade nas aulas teóricas, maior envolvimento do professor responsável pela disciplina na condução das discussões e realização de atividades desta natureza como revisão para as avaliações:

\footnotetext{
"As atividades são boas e otimizam o aprendizado porém deveriam ser incorporadas durante as aulas..."

"Com relação às atividades, acredito quer elas deveriam ser antes das provas como maneira de revisar a matéria..."

"Funcionou muito bem... mas quem sabe com uma participação mais direta do professor responsável, isso é, lê-se o livro e mostra os pontos que são interessantes mostrando a ligação dos livros com a matéria dada em sala de aula".
}

Acreditamos que a sugestões feitas por alguns alunos a respeito da participação do professor corroboram considerações feitas na literatura, como as de Chaves, Mezzomo e Terrazzan (2001a, 2001b, 2001c), que enfatizam a importância do mesmo no trabalho com tais textos.

Quanto às concepções dos estudantes sobre as contribuições da atividade para o aperfeiçoamento/desenvolvimento de algumas habilidades, obtivemos os seguintes resultados:

i) Uma quantidade considerável de alunos $(65,0 \%)$ acredita que a atividade influenciou nas suas habilidades de leitura e compreensão de textos de divulgação científica; 
ii) A maioria dos alunos $(82,5 \%)$ considera que a proposta aplicada contribuiu nas suas capacidades em trabalhar em grupo;

iii) Cerca de três quartos dos alunos $(77,5 \%)$ consideram que a leitura dos textos auxiliou no entendimento sobre a forma como a ciência é construída, ou seja, a forma como a pesquisa em química é realizada;

iv) Uma grande parte dos alunos $(70,0 \%)$ julga que as atividades também contribuíram no desenvolvimento de habilidades em comunicação oral e escrita.

Os resultados obtidos nos mostram um nível de satisfação significativo por parte dos alunos, pois a maioria deles afirma que a atividade com os textos exerceu uma influência positiva em habilidades relevantes para a sua formação. Podemos constatar essa satisfação nos comentários apresentados pelos estudantes nos questionários, alguns deles apresentados no Quadro 1. 


\begin{tabular}{|c|c|}
\hline $\begin{array}{c}\text { Habilidades } \\
\text { desenvolvidas / aperfeiçoadas a } \\
\text { partir da realização das } \\
\text { atividades }\end{array}$ & $\begin{array}{l}\text { Alguns comentários apresentados pelos } \\
\text { estudantes }\end{array}$ \\
\hline \multirow{2}{*}{$\begin{array}{l}\text { Leitura e compreensão de textos } \\
\text { de divulgação científica }\end{array}$} & $\begin{array}{l}\text { "Possibilitou minha familiarização com textos de } \\
\text { divulgação científica." }\end{array}$ \\
\hline & $\begin{array}{l}\text { "Me familiarizaram com os termos utilizados em } \\
\text { textos cientificos." }\end{array}$ \\
\hline \multirow{4}{*}{$\begin{array}{l}\text { Realização de trabalhos em } \\
\text { grupo }\end{array}$} & $\begin{array}{l}\text { "Trabalhar em grupo é sempre interessante, } \\
\text { ainda mais numa sala que acabou de se formar } \\
\text { e conhecer. As opiniões são muito diferentes } \\
\text { então sempre gera discussões e troca de } \\
\text { experiências". }\end{array}$ \\
\hline & $\begin{array}{l}\text { "Sim. Acho essencial trabalhar em grupo, tenho } \\
\text { dificuldades com isso mas encaro toda vez como } \\
\text { um desafio e aprendo muito". }\end{array}$ \\
\hline & $\begin{array}{l}\text { "Sim, pois todos os membros do grupo } \\
\text { participavam e era preciso respeitar opiniões e } \\
\text { chegar a um consenso". }\end{array}$ \\
\hline & $\begin{array}{l}\text { "A atividade em grupo exige repartição do } \\
\text { trabalho (...) além do mais é sempre importante } \\
\text { saber ouvir a opinião do outro". }\end{array}$ \\
\hline \multirow{4}{*}{$\begin{array}{l}\text { Compreensão sobre o processo } \\
\text { de construção da ciência }\end{array}$} & $\begin{array}{l}\text { "O livro nos fornece uma nova perspectiva do } \\
\text { mundo da ciência, abordando alguns dos } \\
\text { primórdios da Química, nos mostrando sua } \\
\text { evolução e construção, sempre em } \\
\text { aperfeiçoamento e aprofundamento...". }\end{array}$ \\
\hline & $\begin{array}{l}\text { "O conteúdo apresentado nos capitulos Luz } \\
\text { brilhante e O jardim de Mendeleiev certamente } \\
\text { contribuiram para o meu aprendizado, pois } \\
\text { através deles pude conhecer melhor a vida dos } \\
\text { cientistas e suas 'lutas' diárias...". }\end{array}$ \\
\hline & $\begin{array}{l}\text { "Sim, o texto mostra como a persistência pode } \\
\text { levar a novas descobertas". }\end{array}$ \\
\hline & $\begin{array}{l}\text { "Ocorreu uma percepção do tempo de duração } \\
\text { das pesquisas e a importância de vários } \\
\text { trabalhos para provar uma dada teoria". }\end{array}$ \\
\hline \multirow[t]{2}{*}{ Comunicação oral e escrita } & $\begin{array}{l}\text { "Quando estamos trabalhando com atividades } \\
\text { de escrita e leitura estamos cada vez nos } \\
\text { aperfeiçoando mais." }\end{array}$ \\
\hline & $\begin{array}{l}\text { "A leitura me mostrou palavras que eu não } \\
\text { possuia conhecimento". }\end{array}$ \\
\hline
\end{tabular}

Quadro 1 - Comentários dos alunos em relação às habilidades desenvolvidas/aperfeiçoadas a partir da realização da atividade.

Consideramos que os relatos apontados pelos alunos em relação à influência das atividades sobre as habilidades citadas vêm ao encontro de algumas considerações presentes na literatura. Com relação ao desenvolvimento de habilidades referentes à leitura e compreensão de textos de divulgação científica, Korpan et al. (1997) sugerem que artigos e textos 
desta natureza são uma fonte persuasiva e importante de novos conhecimentos científicos e a leitura dos mesmos se traduz em uma importante forma de alfabetização científica.

Sobre capacidades relacionadas ao trabalho em grupo, Ricon e Almeida (1991), a partir de resultados da análise de ensaios com o uso de textos em sala de aula, destacam que tais textos propiciaram aos alunos a oportunidade de tomarem conhecimento de um universo de conhecimentos e informações e, deste modo, participarem mais efetivamente nas discussões. O trabalho desses autores também reforça nossos resultados com relação aos textos promoverem melhorias na comunicação oral e escrita dos estudantes. Ao demonstrarem que esses textos - por instigarem a curiosidade e o prazer de leitura - contribuíram para a instauração de um contexto de leitura efetivo em sala de aula e para criação de hábitos de leitura. Deste modo, entendemos que a criação desses hábitos por parte dos alunos seja condição importante para o desenvolvimento de tais habilidades.

Muitos trabalhos reportados na literatura consolidam as opiniões dos alunos com relação às contribuições da leitura de textos de divulgação cientifica para o entendimento de aspectos da construção do conhecimento científico. Terrazzan e Gabana (2003) afirmam que os textos de divulgação científica, por apresentarem discussões a respeito do processo de construção da ciência, auxiliam o leitor a formar idéias mais adequadas do que seja o "fazer científico", diminuindo o grau de mistificação que atravessa a imagem da ciência.

Por fim, quando questionamos os alunos se participariam novamente de atividades com textos de divulgação científica em outras disciplinas, 
recebemos, em grande maioria, respostas favoráveis a essa possibilidade, como mostram os pronunciamentos a seguir:

"Seria interessante. O curso de química é um curso pesado e trabalhar com esse tipo de material o deixaria menos denso".

"Sim, pois métodos alternativos favorecem o entendimento. A saída da sala de aula é viável para o recrutamento dos alunos ao interesse pelo estudo, rompendo o tradicionalismo que tanto motiva a insatisfação pela constância do estudo". 


\section{CONSIDERAÇÕES FINAIS}

A possibilidade de utilização de textos de divulgação científica em contextos escolares vem sendo amplamente discutida nos últimos anos (ALMEIDA, 1998; SALÉM; KAWAMURA, 1999; MARTINS; CASSAB; ROCHA, 2001; MARANDINO et al., 2003; TERRAZZAN; GABANA, 2003; SILVA; ALMEIDA, 2005; NASCIMENTO; SOUZA, 2007), no entanto, pesquisas baseadas em experiências reais de sala de aula com textos de divulgação científica são escassas, sobretudo no ensino superior de química (DYBOWSKI, 2001; CARROLL; SEEMAN, 2001; OSORIO et al., 2005; SAMET; HIGGINS, 2005; OSORIO; TIEDEMANN; PORTO, 2007). Neste sentido, elaboramos e aplicamos uma proposta de ensino baseada na utilização de textos extraídos do livro de divulgação científica Tio Tungstênio: memórias de uma infância química, de Oliver Sacks, em uma disciplina de graduação em química. O acompanhamento da aplicação da proposta e a análise do material produzido pelos alunos - subsidiada pelo referencial 
teórico da Análise de Discurso de linha francesa - nos permitem tecer algumas considerações sobre os resultados dela provenientes.

A noção de tipologia do discurso, divulgada por Orlandi (1996b), permitiu a identificação, nas questões formuladas pelos alunos, de deslocamentos do discurso pedagógico - marcado pela paráfrase, portanto, predominantemente autoritário - para um discurso polêmico. Essa transição deu lugar à polissemia e permitiu a reversibilidade e a disputa pela verdade, a ponto de tornar relevante a multiplicidade de sentidos e, conseqüentemente, a voz dos estudantes, rompendo a exclusividade do professor e do material didático como agentes locutores. Acreditamos que tal fato se deva à leitura dos textos, uma vez que não identificamos indícios de discurso polêmico nas perguntas feitas pelos estudantes durante as aulas tradicionais. Concebemos esta mudança de discurso autoritário para polêmico como um aspecto positivo proporcionado pela leitura dos textos de divulgação científica, pois indica um progresso com relação à capacidade crítica dos alunos, qualidade importante que deve ser estimulada dentro do ensino superior de química.

A análise dos textos produzidos pelos alunos, a partir da noção de autoria, também divulgada por Orlandi (1996b), nos permitiu constatar a presença dos três tipos de repetição - empírica, formal e histórica - em todos eles. Verificamos que a maioria dos alunos, após as atividades de leitura, conseguiu produzir textos em que ocorria a repetição histórica. Nesses casos, o exercício da função autor foi realizado de diferentes formas, nas quais os alunos lançaram mão da produção de seus textos para assumir diversos posicionamentos. Tal ocorrência assenta a afirmação feita por 
Orlandi (2000) de que os modos de leitura são muito variáveis e indicam diferentes formas de relações dos leitores com o texto.

Embora em alguns textos o uso das repetições empírica e formal tenha sido constante, não consideramos que este fato confira um descrédito aos estudantes ou à proposta de ensino, uma vez que, segundo Silva e Almeida (2005), transformar o sentido único em múltiplos não é tarefa simples, pois há memórias que tendem a repeti-lo, incrustadas em práticas sedimentadas em sala de aula.

Consideramos que a multiplicidade de sentidos observada a partir das análises - tanto das questões formuladas pelos alunos, como dos textos produzidos por eles - seja resultado de um contexto que permitiu aos estudantes configurarem suas interpretações, contexto este, podemos sugerir, propiciado pela leitura dos textos de divulgação científica.

As impressões expressas pelos estudantes com relação à proposta de ensino corroboram a sua importância, ao considerarem que as atividades contribuíram para o desenvolvimento de habilidades necessárias à sua formação, como a leitura e interpretação de textos de divulgação científica, realização de trabalhos em grupo, aperfeiçoamento da comunicação oral e escrita e entendimento sobre o processo de construção do conhecimento científico. Além disso, as opiniões manifestadas indicam uma boa receptividade por parte dos alunos com relação à proposta e a boa relação estabelecida entre eles e os textos.

Os resultados obtidos indicam a viabilidade da proposta que, além de estimular o desenvolvimento de habilidades relevantes para os estudantes e apresentar boa receptividade entre eles, aponta o texto de divulgação 
científica como mediador para a colocação de posicionamentos incomuns no ensino superior de química. Esses resultados sugerem uma possivel postura critica por parte dos estudantes, condição importante para que se tornem participantes ativos, tanto da comunidade científica, como de outras comunidades discursivas. 


\section{REFERÊNCIAS BIBLIOGRÁFICAS}

ABREU, L. N.; MASSI, L.; QUEIROZ, S. L. Textos de divulgação científica no ensino superior de química. In: ENCONTRO NACIONAL DE PESQUISA EM EDUCAÇÃO EM CIÊNCIAS, 6., 2007, Florianópolis. Atas... Florianópolis: Associação Brasileira de Pesquisa em Educação em Ciências, 2007. CD-ROM.

ADINOLFI, V. T. S. Ética e mídia: os periódicos de divulgação científica brasileiros e seus discursos sobre ética na ciência. 2005. 157 f. Dissertação (Mestrado em Educação) - Faculdade de Educação, Universidade Estadual de Campinas, Campinas, 2005.

AIRES, J. A.; BOER, N.; BRANDT, C. F.; FERRARI, N.; GOMES, M. G.; OLIVEIRA, V. L. B.; PAZ, A. M.; PINHEIRO, N. A. M.; SCHEID, N. M. J. Divulgação científica na sala de aula: um estudo sobre a contribuição da revista ciência hoje das crianças. In: ENCONTRO NACIONAL DE PESQUISA EM EDUCAÇÃO EM CIÊNCIAS, 4., 2003, Bauru. Atas... Bauru: Associação Brasileira de Pesquisa em Educação em Ciências, 2003. CD-ROM.

ALFONSO-GOLDFARB, A. M. O que é história da ciência. São Paulo: Editora Brasiliense, 1995. 93 p.

ALMEIDA, M. J. P. M. Questões formuladas e representações de alunos e professores na leitura de textos de divulgação científica. In: ENCONTRO NACIONAL DE PESQUISA EM EDUCAÇÃO EM CIÊNCIAS, 1., 1997, Águas de Lindóia. Atas... Águas de Lindóia: Associação Brasileira de Pesquisa em Educação em Ciências, 1997. CD-ROM.

. O texto escrito na educação em física: enfoque na divulgação científica. In: ALMEIDA, M.J.P.M.; SILVA, H.C. (Org.). Linguagens, leituras e ensino da ciência. Campinas: Mercado de Letras, 1998. p. 53-68.

ALMEIDA, M. J. P. M.; RICON, A. E. Divulgação científica e texto literário: uma perspectiva cultural em aulas de física. Caderno Catarinense de Ensino de Fisica, v. 10, n. 1, p. 7-13, 1993.

AMORIM, L. M.; MASSARANI, L. Jornalismo científico: um estudo de caso de três jornais brasileiros. In: ENCONTRO NACIONAL DE PESQUISA EM EDUCAÇÃO EM CIÊNCIAS, 5., 2005, Bauru. Atas... Bauru: Associação Brasileira de Pesquisa em Educação em Ciências, 2005. CD-ROM.

AUTHIER-REVUZ, J. A encenação da comunicação no discurso da divulgação científica. In: Palavras incertas: as não-coincidências do dizer. São Paulo: Unicamp, 1998. p. 107-131.

BAKHTIN, M. Estética da criação verbal. São Paulo: Martins Fontes, 2003. $476 \mathrm{p}$. 
BINSFELD, S. S.; ZANON, L. B. A participação de materiais de divulgação científica no desenvolvimento de uma situação de estudo no ensino médio. In: REUNIÃO ANUAL DA SOCIEDADE BRASILEIRA DE QUÍMICA, 30., 2007, Águas de Lindóia. Anais... Águas de Lindóia: Sociedade Brasileira de Química, 2007. CD-ROM.

BRASIL. Secretária de Educação Fundamental. Parâmetros Curriculares Nacionais: Ciências Naturais. Brasília, MEC/SEF, 1997. Disponível em: <http://portal.mec.gov.br/seb/arquivos/pdf/livro04.pdf>. Acesso em: 22 jun. 2008.

BROTERO, P. P.; MARCONDES, M. E. R. Análise do discurso na divulgação científica - um caso de química. In: ENCONTRO NACIONAL DE PESQUISA EM EDUCAÇÃO EM CIÊNCIAS, 5., 2005, Bauru. Atas... Bauru: Associação Brasileira de Pesquisa em Educação em Ciências, 2005. CD-ROM.

. Uso de texto de divulgação científica no ensino de química no ensino médio - um estudo de discursos. In: ENCONTRO NACIONAL DE ENSINO DE QUÍMICA, 13., 2006, Campinas. Anais... Campinas: Sociedade Brasileira de Química, 2006. CD-ROM.

CABRAL, C. G. Espelho, espelho meu: a clonagem num livro de divulgação científica. In: ENCONTRO NACIONAL DE PESQUISA EM EDUCAÇÃO EM CIÊNCIAS, 4., 2003, Bauru. Atas... Bauru: Associação Brasileira de Pesquisa em Educação em Ciências, 2003. CD-ROM.

CAMPOS, P. T.; FONSECA, C. S.; DUARTE, A. T.; LAMEIRO, M. G. S. Diário metálico. In: ENCONTRO DE DEBATES SOBRE O ENSINO DE QUÍMICA, 25., 2005, Ijuí. Anais... Ijuí: Unijuí, 2005. CD-ROM.

CARROLL, F. A.; SEEMAN, J. I. Placing science into its human context: using scientific autobiography to teach chemistry. Journal of Chemical Education, v. 78, n. 12, p. 1618-1622, 2001.

CARVALHO, A. M. P. O uso do vídeo na tomada de dados: pesquisando o desenvolvimento do ensino em sala de aula. Pro-posições, v. 7, n. 1, p. 5-13, 1996.

CHAGAS, P.; BARBOSA, E. A.; NAVEGA, E. A. Analfabetismo científico e a mídia: estratégias de integração interdisciplinar. In: ENCONTRO NACIONAL DE ENSINO DE QUÍMICA, 12., 2004, Goiânia. Anais... Goiânia: Sociedade Brasileira de Química, 2004. ref. ENEQ-120.

CHASSOT, A. Tio Tungstênio: memórias de uma infância química, 2005. Disponivel em: <http://www.leialivro.com.br/texto.php?uid=3265>. Acesso em: 22 jun. 2008. 
CHAVES, T. V.; MEZZOMO, J.; TERRAZZAN, E. A. Textos de divulgação científica como recurso didático para o ensino-aprendizagem da física clássica: exemplos em termodinâmica e eletromagnetismo. In: ENCONTRO NACIONAL DE PESQUISA EM EDUCAÇÃO EM CIÊNCIAS, 3., 2001, Atibaia. Atas... Atibaia: Associação Brasileira de Pesquisa em Educação em Ciências, 2001a. CD-ROM.

. Textos de divulgação científica como recurso didático para o ensino-aprendizagem da física moderna: um exemplo em relatividade. In: ENCONTRO NACIONAL DE PESQUISA EM EDUCAÇÃO EM CIÊNCIAS, 3., 2001, Atibaia. Atas... Atibaia: Associação Brasileira de Pesquisa em Educação em Ciências, 2001b. CD-ROM.

Avaliando práticas didáticas de utilização de textos de divulgação científica como recurso didático em aulas de física no ensino médio. In: ENCONTRO NACIONAL DE PESQUISA EM EDUCAÇÃO EM CIÊNCIAS, 3., 2001, Atibaia. Atas... Atibaia: Associação Brasileira de Pesquisa em Educação em Ciências, 2001c. CD-ROM.

COMEFORD, L. Writing assignments in physical chemistry. Journal of Chemical Education, v. 74, n. 4, p. 392, 1997.

COPOLLA, B.P.; EGE, S.N.; LAWTON, R.G. The University of Michigan undergraduate chemistry curriculum 2. Instructional strategies and assessment. Journal of Chemical Education, v. 74, n. 1, p. 84-94, 1997.

COSTA, A. P. B.; CORREA, A. L. L.; NASCIMENTO, S. S. A multimodalidade no discurso da divulgação científica. In: ENCONTRO NACIONAL DE PESQUISA EM EDUCAÇÃO EM CIÊNCIAS, 4., 2003, Bauru. Atas... Bauru: Associação Brasileira de Pesquisa em Educação em Ciências, 2003. CD-ROM.

CUNHA, M. B.; GIORDAN, M. A mídia e o conhecimento químico. In: ENCONTRO NACIONAL DE ENSINO DE QUÍMICA, 13., 2006, Campinas. Anais... Campinas: Sociedade Brasileira de Quimica, 2006. CD-ROM.

CUSTÓDIO, J. F.; RICARDO, E. C. Divulgação científica e indústria cultural: considerações acerca de uma semiformação. In: ENCONTRO NACIONAL DE PESQUISA EM EDUCAÇÃO EM CIÊNCIAS, 4., 2003, Bauru. Atas... Bauru: Associação Brasileira de Pesquisa em Educação em Ciências, 2003. CD-ROM.

DONNELLY, J.F. Humanizing Science Education. Science Education, v. 88, p. 762-784, 2004.

DYBOWSKI, C. A course in the history of physical chemistry with an emphasis on writing. Journal of Chemical Education, v. 78, n. 12, p. 1623-1625, 2001. 
ELIEL, E. L. From Cologne to Chapel Hill. Washington: American Chemical Society, 1990. 138 p.

FARIA, R. B. Tio Tungstênio - memórias de uma infância química. Carta ao editor. Quimica Nova, v. 26, n. 4, p. 625, 2003.

FERNANDES, C. A.; FERREIRA, L. C. Discursos em confronto: veja e bundas, o MST em questão. In: GREGOLIN, M. R.; CRUVINEL, M. F.; KHALIL, M. G. (Org) Análise do discurso: entornos do sentido. São Paulo: Cultura Acadêmica Editora, 2001. p. 229-240.

FERRARI, P. C.; ANGOTTI, J. A.; CRUZ, F. F. S. A divulgação científica na educação escolar: discutindo um exemplo. In: ENCONTRO NACIONAL DE PESQUISA EM EDUCAÇÃO EM CIÊNCIAS, 5., 2005, Bauru. Atas... Bauru: Associação Brasileira de Pesquisa em Educação em Ciências, 2005. CD-ROM.

FERRARI, P. C.; ANGOTTI, J. A.; TRAGTENBERG, M. H. R. Utilização de textos de divulgação científica sobre a teoria do caos na educação. In: ENCONTRO NACIONAL DE PESQUISA EM EDUCAÇÃO EM CIÊNCIAS, 5., 2005, Bauru. Atas... Bauru: Associação Brasileira de Pesquisa em Educação em Ciências, 2005. CD-ROM.

FERREIRA, M. Temáticas superinteressantes na mídia e temas transversais na educação em uma análise cultural. In: ENCONTRO NACIONAL DE PESQUISA EM EDUCAÇÃO EM CIÊNCIAS, 4., 2003, Bauru. Atas... Bauru: Associação Brasileira de Pesquisa em Educação em Ciências, 2003. CD-ROM.

FIELD'S, K. A. P.; RASTRELO, M. R. O uso de artigos eletrônicos para o ensino de forças intermoleculares para alunos do curso de biologia. In: ENCONTRO NACIONAL DE ENSINO DE QUÍMICA, 12., 2004, Goiânia. Anais... Goiânia: Sociedade Brasileira de Química, 2004. ref. ENEQ-187.

FOUCAULT, M. Arqueologia do saber. Petrópolis: Vozes, 1972. 260 p. O que é um autor? Lisboa: Passagens, 2000. 160 p.

A ordem do discurso. São Paulo: Loyola, 2004. 74 p.

FOUREZ, G. A construção das ciências: introdução a filosofia e a ética das ciências. São Paulo: Unesp, 1995. 319 p.

GABANA, M.; LUNARDI, G.; TERRAZZAN, E. A. Textos de divulgação científica: avaliando uma estratégia didática para o ensino médio. In: ENCONTRO NACIONAL DE PESQUISA EM EDUCAÇÃO EM CIÊNCIAS, 4., 2003, Bauru. Atas... Bauru: Associação Brasileira de Pesquisa em Educação em Ciências, 2003. CD-ROM. 
GALAGOVSKY, L.; CUÑADO, C.; PALMIÉRI, L. J. QUEIROZ, S. L. Textos de divulgação científica no ensino-aprendizagem dos tópicos "Combustão" e "Tabela Periódica". In: REUNIÃO ANUAL DA SOCIEDADE BRASILEIRA DE QUÍMICA, 30., 2007, Águas de Lindóia. Anais... Águas de Lindóia: Sociedade Brasileira de Química, 2007. CD-ROM.

GAMA, L. C. Divulgação científica: leituras em classes de ensino médio. 2005. 216 f. Dissertação (Mestrado em Educação) - Faculdade de Educação, Universidade Estadual de Campinas, Campinas, 2005.

GERMANO, M. G.; KULESZA, W. A. Popularização da ciência: uma revisão conceitual. Caderno Catarinense de Ensino de Física, v. 24, n. 1, p. 7-25, 2007.

GOLDBACH, T.; EL-HANI, C.; MARTINS, R. C. Idéias sobre genes em revistas de divulgação científica e em glossários virtuais. In: ENCONTRO NACIONAL DE PESQUISA EM EDUCAÇÃO EM CIÊNCIAS, 5., 2005, Bauru. Atas... Bauru: Associação Brasileira de Pesquisa em Educação em Ciências, 2005. CD-ROM.

GOMES, M. C.; DA POIAN, A. T.; GOLDBACH, T. Revistas de divulgação científica: concepções sobre os temas alimentação-metabolismo energético. In: ENCONTRO NACIONAL DE PESQUISA EM EDUCAÇÃO EM CIÊNCIAS, 6., 2007, Florianópolis. Atas... Florianópolis: Associação Brasileira de Pesquisa em Educação em Ciências, 2007. CD-ROM.

GOUVEAA, G.; BARROS, H. L. Transformação do texto científico em texto de divulgação: o caso da ciência hoje das crianças. In: ENCONTRO NACIONAL DE PESQUISA EM EDUCAÇÃO EM CIÊNCIAS, 3., 2001, Atibaia. Atas... Atibaia: Associação Brasileira de Pesquisa em Educação em Ciências, 2001. CD-ROM.

GREGOLIN, M.R.V. Análise do Discurso: os sentidos e suas movências. In: GREGOLIN, M. R.; CRUVINEL, M. F.; KHALIL, M. G. (Org.) Análise do discurso: entornos do sentido. São Paulo: Cultura Acadêmica Editora, 2001. p. 9-34.

. Sentido, sujeito e memória: com o que sonha nossa vã autoria? In: GREGOLIN, M.R.V.; BARONAS, R. (Org.). Análise do discurso: as materialidades do sentido. São Carlos: Clara Luz, 2003. p. 47-58.

GRIBBIN, J. In search of Schrödinger's cat: quantum physics and reality. New York: Bantam, 1984. 302 p.

HOUAISS: dicionário eletrônico da língua portuguesa. Versão 1.0. Rio de Janeiro: Editora Objetiva, 2001. 1 CD-ROM. 
IANINI, A. M. N.; FARES, D. C.; BIZERRA, A.; MARANDINO, M. Pesquisa em divulgação científica: um levantamento de referenciais teóricos nacionais. In: ENCONTRO NACIONAL DE PESQUISA EM EDUCAÇÃO EM CIÊNCIAS, 6., 2007, Florianópolis. Atas... Florianópolis: Associação Brasileira de Pesquisa em Educação em Ciências, 2007. CD-ROM.

KEMPER, A.; ZIMMERMANN, E.; GASTAL, M. L. A. Conceitos de evolução na revista superinteressante. In: ENCONTRO NACIONAL DE PESQUISA EM EDUCAÇÃO EM CIÊNCIAS, 6., 2007, Florianópolis. Atas... Florianópolis: Associação Brasileira de Pesquisa em Educação em Ciências, 2007. CD-ROM.

KORPAN, C. A.; BISANZ, G. L.; BISANZ, J.; HENDERSON, J. M. Assessing literacy in science: evaluation of scientific news briefs. Science Education, v. 81 , n. 5, p. 515-532, 1997.

LAIDLER, K. The world of physical chemistry. Oxford: Oxford University Press, 1993. 476 p.

LE COUTEUR, P.; BURRESON, J. Napoleon's buttons: how 17 molecules changed history. New York: Tarcher/Putnam, 2003. 376 p.

LEGEY, C.; COUTINHO, C. M. L. M. Divulgação de biologia celular através da mídia impressa brasileira - estudo de caso de dois jornais e três revistas. In: ENCONTRO NACIONAL DE PESQUISA EM EDUCAÇÃO EM CIÊNCIAS, 6., 2007, Florianópolis. Atas... Florianópolis: Associação Brasileira de Pesquisa em Educação em Ciências, 2007. CD-ROM.

LEVI, P. A tabela periódica. Tradução de Luiz Sergio Henrique. Rio de Janeiro: Relume-Dumará, 1994. 258 p.

LINDINO, C. A.; CUNHA, M. B. Divulgação científica através de textos em jornal. In: ENCONTRO NACIONAL DE ENSINO DE QUÍMICA, 12., 2004, Goiânia. Anais... Goiânia: Sociedade Brasileira de Química, 2004. ref. ENEQ-064.

LÜDKE, M.; ANDRÉ, M. E. D. A. Pesquisa em educação: abordagens qualitativas. São Paulo: Editora Pedagógica e Universidade de São Paulo, 1986. 99 p.

MAINGUENEAU, D. Novas tendências em análise do discurso. Campinas: Pontes, 1997. 198 p.

MALDIDIER, D. A inquietação do discurso: re-ler Michel Pêcheux hoje. Campinas: Pontes Editores, 2003. 110 p. 
MARANDINO, M.; SILVEIRA, R. V. M.; CHELINI, M. J.; FERNANDES, A. B.; RACHID, V.; MARTINS, L. C.; LOURENÇO, M. F.; FERNANDES, J. A.; FLORENTINO, H. A. A educação não formal e a divulgação científica: o que pensa quem faz. In: ENCONTRO NACIONAL DE PESQUISA EM EDUCAÇÃO EM CIÊNCIAS, 4., 2003, Bauru. Atas... Bauru: Associação Brasileira de Pesquisa em Educação em Ciências, 2003. CD-ROM.

MARTINS, I.; ANDRADE, I.; TRIGO, E.; ROCHA, M. B.; CRUZ, U. M.; ROCHA, A. D. Divulgação científica na sala de aula: as escolhas dos professores. In: ENCONTRO NACIONAL DE PESQUISA EM EDUCAÇÃO EM CIÊNCIAS, 3., 2001, Atibaia. Atas... Atibaia: Associação Brasileira de Pesquisa em Educação em Ciências, 2001. CD-ROM.

MARTINS, I.; CASSAB, M.; ROCHA, M. B. Análise do processo de re-elaboração discursiva de um texto de divulgação científica para um texto didático. In: ENCONTRO NACIONAL DE PESQUISA EM EDUCAÇÃO EM CIÊNCIAS, 3., 2001, Atibaia. Atas... Atibaia: Associação Brasileira de Pesquisa em Educação em Ciências, 2001. CD-ROM.

MARTINS, I.; NASCIMENTO, T. G.; ABREU, T. B. Clonagem na sala de aula: um exemplo do uso didático de um texto de divulgação científica.

Investigações em Ensino de Ciências, v.9, n.1, p. 95-111, 2004.

MASSI, L. Contribuições da Iniciação Científica na apropriação da linguagem científica por alunos de graduação em química. 2008. $227 \mathrm{f}$. Dissertação (Mestrado em Ciências) - Instituto de Química de São Carlos, Universidade de São Paulo, São Carlos, 2008.

MENEGAT, T. M. C.; CLEMENT, L.; TERRAZZAN, E. A. Textos de divulgação científica em aulas de física: uma abordagem investigativa. In: ENCONTRO NACIONAL DE PESQUISA EM EDUCAÇÃO EM CIÊNCIAS, 6., 2007, Florianópolis. Atas... Florianópolis: Associação Brasileira de Pesquisa em Educação em Ciências, 2007. CD-ROM.

MIRANDA, A. S. Superinteressante: das bancas para a escola. In: ENCONTRO NACIONAL DE PESQUISA EM EDUCAÇÃO EM CIÊNCIAS, 5., 2005, Bauru. Atas... Bauru: Associação Brasileira de Pesquisa em Educação em Ciências, 2005. CD-ROM.

MONTEIRO, M. A.; MONTEIRO, I. C. C.; GASPAR, A. Textos de divulgação científica em sala de aula para o ensino de física. In: ENCONTRO NACIONAL DE PESQUISA EM EDUCAÇÃO EM CIÊNCIAS, 4., 2003, Bauru. Atas... Bauru: Associação Brasileira de Pesquisa em Educação em Ciências, 2003. CD-ROM.

NASCIMENTO, T. G. Contribuições da análise do discurso e da epistemologia de Fleck para a compreensão da divulgação científica e sua introdução em aulas de ciências. Ensaio, v. 7, n. 2, p. 1-18, 2005. 
NASCIMENTO, T. G.; SOUZA, S. C. A produção sobre divulgação científica em eventos de ensino de ciências: vislumbrando tendências. In: ENCONTRO NACIONAL DE PESQUISA EM EDUCAÇÃO EM CIÊNCIAS, 5., 2005, Bauru. Atas... Bauru: Associação Brasileira de Pesquisa em Educação em Ciências, 2005. CD-ROM.

Modos de leitura de textos de divulgação científica. In: ENCONTRO

NACIONAL DE PESQUISA EM EDUCAÇÃO EM CIÊNCIAS, 6., 2007, Florianópolis. Atas... Florianópolis: Associação Brasileira de Pesquisa em Educação em Ciências, 2007. CD-ROM.

ORLANDI, E. P. Interpretação: autoria, leituras e efeitos do trabalho simbólico. Petrópolis: Editora Vozes, 1996a. 150 p.

A linguagem e seu funcionamento: as formas do discurso. Campinas: Pontes, 1996b. 276 p.

Discurso e leitura. São Paulo: Cortez, 2000. 118 p.

Discurso e texto: formulação e circulação de sentidos. Campinas: Pontes, 2001. $218 \mathrm{p}$.

Análise do discurso: princípios e procedimentos.

Campinas: Pontes, 2002. 100 p.

OLIVEIRA, O. B. Possibilidades da escrita no avanço do senso comum para o saber científico na $\mathbf{8}^{\mathbf{a}}$ série do ensino fundamental. 2001. $163 \mathrm{f}$. Dissertação (Mestrado em Educação) - Faculdade de Educação, Universidade Estadual de Campinas, Campinas, 2001.

OSORIO, V. K. L.; TIEDEMANN, P. W.; PORTO, P. A. Primo Levi and The Periodic Table: teaching chemistry using a literary text. Journal of Chemical Education, v. 84, n. 5, p. 775-778, 2007.

OSORIO, V. K. L.; PORTO, P. A.; TIEDEMANN, P. W.; CORIO, P. Primo Levi e A Tabela Periódica: explorando possibilidades didáticas de um texto literário. In: REUNIÃO ANUAL DA SOCIEDADE BRASILEIRA DE QUÍMICA, 28., 2005, Poços de Caldas. Anais... Poços de Caldas: Sociedade Brasileira de Química 2005. CD-ROM.

PÊCHEUX, M. Semântica e discurso: uma crítica à afirmação do óbvio. Campinas: Editora da Unicamp, 1995. 317 p.

Análise automática do discurso (AAD-69). In: GADET, F.; HAK, F. (Org) Por uma análise automática do discurso: uma introdução à obra de Michel Pêcheux. Campinas: Pontes, 1997. p. 61-162.

PENROSE, R. O grande, o pequeno e a mente humana. São Paulo: Editora UNESP, 1998. 193 p. 
PEREIRA, L. V. Clonagem: fatos e mitos. São Paulo: Editora Moderna, 2002. $80 \mathrm{p}$.

PEREIRA, M. C.; PINTO NETO, P. C. O uso da revista Superinteressante nas aulas de química. Existe alguma inovação? In: ENCONTRO NACIONAL DE PESQUISA EM EDUCAÇÃO EM CIÊNCIAS, 4., 2003, Bauru. Atas... Bauru: Associação Brasileira de Pesquisa em Educação em Ciências, 2003. CD-ROM.

PEREZ, J. R. B.; CALUZI, J. J. A divulgação científica e as distorções conceituais do invariante massa-energia relativístico. In: ENCONTRO NACIONAL DE PESQUISA EM EDUCAÇÃO EM CIÊNCIAS, 4., 2003, Bauru. Atas... Bauru: Associação Brasileira de Pesquisa em Educação em Ciências, 2003. CD-ROM.

PRESTES, R. F.; SILVA, A. M. M. Artigos de divulgação científica para o estudo de problemas energéticos com enfoque CTS. In: ENCONTRO NACIONAL DE PESQUISA EM EDUCAÇÃO EM CIÊNCIAS, 6., 2007, Florianópolis. Atas... Florianópolis: Associação Brasileira de Pesquisa em Educação em Ciências, 2007. CD-ROM.

PUIATI, L. L.; BOROWSKY, H. G.; TERRAZZAN, E. A. O texto de divulgação científica como recurso para o ensino de ciências na educação básica: um levantamento das produções nos enpec. In: ENCONTRO NACIONAL DE PESQUISA EM EDUCAÇÃO EM CIÊNCIAS, 6., 2007, Florianópolis. Atas... Florianópolis: Associação Brasileira de Pesquisa em Educação em Ciências, 2007. CD-ROM.

QUEIROZ, S. L.; SÁ, L. P. Identificação de termos argumentativos em artigos de divulgação científica por alunos de graduação em química. In:

ENCONTRO DE DEBATES SOBRE O ENSINO DE QUÍMICA, 26., 2006, Santa Cruz do Sul. Anais... Santa Cruz do Sul: UNISC, 2006. CD-ROM.

RIBEIRO, R. A.; KAWAMURA, M. R. A ciência em diferentes vozes: uma análise de textos de divulgação científica. In: ENCONTRO NACIONAL DE PESQUISA EM EDUCAÇÃO EM CIÊNCIAS, 5., 2005, Bauru. Atas... Bauru: Associação Brasileira de Pesquisa em Educação em Ciências, 2005. CD-ROM.

RIBEIRO, M. H. O.; COSTA NETO, J. J. G.; PESSOA, P. A. P.; SILVA, H. R.; SIQUEIRA, L. F. S.; LOPES, R. B.; SANTOS, H. C. C.; FARIAS, T. M.; CARVALHO, R. C. S.; RANGEL, J. H. G.; OLIVEIRA, M. M. O uso de um jornal como uma maneira multidisciplinar e divertida de se aprender a química. In: ENCONTRO NACIONAL DE ENSINO DE QUÍMICA, 13., 2006, Campinas. Anais... Campinas: Sociedade Brasileira de Química, 2006. CD-ROM.

RICON, A. E.; ALMEIDA, M. J. P. M. Ensino da fisica e leitura. Leitura: Teoria e Prática, v. 10, n. 18, p. 716, 1991. 
ROCHA, M. B.; MARTINS, I. O professor e a divulgação científica na sala de aula. In: ENCONTRO NACIONAL DE PESQUISA EM EDUCAÇÃO EM CIÊNCIAS, 3., 2001, Atibaia. Atas... Atibaia: Associação Brasileira de Pesquisa em Educação em Ciências, 2001. CD-ROM.

RODRIGUES, E. Língua e corporalidade: discurso, corpo e a construção de sentidos no mundo social. In: GREGOLIN, M. R.; CRUVINEL, M. F.; KHALIL, M. G. (Org) Análise do discurso: entornos do sentido. São Paulo: Cultura Acadêmica Editora, 2001. p. 273-282.

SÁ, L. P.; QUEIROZ, S. L. Promovendo a argumentação no ensino superior de química. Química Nova, v. 30, n. 8, p. 2035-2042, 2007.

SACKS, O. Tio Tungstênio: memórias de uma infância química. Tradução de Laura Teixeira Motta. São Paulo: Companhia das Letras, 2002. 334 p.

SALÉM, S.; KAWAMURA, M. R. As perguntas dos leitores nas revistas de divulgação científica: possiveis contribuições ao ensino de física. In: ENCONTRO NACIONAL DE PESQUISA EM EDUCAÇÃO EM CIÊNCIAS, 2., 1999, Valinhos. Atas... Valinhos: Associação Brasileira de Pesquisa em Educação em Ciências, 1999. CD-ROM.

SAMET, C.; HIGGINS, P. J. Napoleon's buttons: teaching the role of chemistry in history. Journal of Chemical Education, v. 82, n. 10, p. 1496-1500, 2005.

\section{SANTOS, G. R. 0 artigo científico no ensino superior de química:} desenvolvendo habilidades de leitura e interpretação. 2006. $122 \mathrm{f}$. Dissertação (Mestrado em Ciências) - Instituto de Química de São Carlos, Universidade de São Paulo, São Carlos, 2006.

SANTOS, G. R.; QUEIROZ, S. L. Leitura e interpretação de artigos científicos por alunos de graduação em química. Ciência e Educação, v. 13, n. 2, p. 193-209, 2007.

SARGENTINI, V. M. O. Discurso e história: a construção de identidade do trabalhador brasileiro. In: GREGOLIN, M. R.; CRUVINEL, M. F.; KHALIL, M. G. (Org) Análise do discurso: entornos do sentido. São Paulo: Cultura Acadêmica Editora, 2001. p. 249-261.

SCHWARTZ, A. T. Uncle Tungsten: memories of a chemical boyhood. Book e media reviews. Journal of Chemical Education, v. 79, n. 3, p. 312, 2002.

SERVOS, J.W. Physical chemistry from Ostwald to Pauling: the making a science in America. Princeton: Princeton University Press, 1990. 430 p. 
SILVA, H. C. Discursos escolares sobre gravitação newtoniana: textos e imagens na física do ensino médio. 2002. 233 f. Tese (Doutorado em Educação) - Faculdade de Educação, Universidade Estadual de Campinas, Campinas, 2002. 2006. O que é divulgação científica? Ciência e Ensino, v. 1, n. 1, p. 53-59,

SILVA, H. C.; ALMEIDA, M. J. P. M. O deslocamento de aspectos do funcionamento do discurso pedagógico pela leitura de textos de divulgação científica em aulas de física. Revista Electrónica de Enseñanza de las Ciencias, v. 4, n. 3, p. 155-179, 2005.

SILVA, J. A.; KAWAMURA, M. R. D. A natureza da luz: uma atividade com textos de divulgação científica em sala de aula. Caderno Catarinense de Ensino de Física, v. 18, n. 3, p. 317-340, 2001.

SILVA, L. L.; TERRAZZAN, E. A. As analogias na divulgação científica: o caso da ciência hoje das crianças. In: ENCONTRO NACIONAL DE PESQUISA EM EDUCAÇÃO EM CIÊNCIAS, 4., 2003, Bauru. Atas... Bauru: Associação Brasileira de Pesquisa em Educação em Ciências, 2003. CD-ROM.

SOARES, A. V.; OLIVEIRA, O. M. M. F. Jornalismo científico aplicado ao processo de aprendizagem. In: ENCONTRO NACIONAL DE ENSINO DE QUÍMICA, 13., 2006, Campinas. Anais... Campinas: Sociedade Brasileira de Quimica, 2006. CD-ROM.

STRACK, R. LOGUERCIO. R. C.; DEL PINO, J. C. Os conceitos estruturantes da literatura de divulgação científica como contribuição ao perfil conceitual químico dos alunos. In: ENCONTRO DE DEBATES SOBRE O ENSINO DE QUÍMICA, 25., 2005, Ijuí. Anais... Ijuí: Unijuí, 2005. CD-ROM.

A literatura de divulgação científica como recurso didático na estrutura da matéria. In: ENCONTRO NACIONAL DE ENSINO DE QUÍMICA, 8., 2006, Campinas. Anais... Campinas: Sociedade Brasileira de Química, 2006a. CD-ROM.

- Uma autobiografia e o conhecimento químico: as possiveis contribuições do livro 'Tio Tungstênio' às aulas de química. In: REUNIÃO ANUAL DA SOCIEDADE BRASILEIRA DE QUÍMICA, 29., 2006, Águas de Lindóia. Anais... Águas de Lindóia: Sociedade Brasileira de Química, 2006b. CD-ROM.

Linguagem e interpretações de professores universitários sobre literatura de divulgação científica. In: ENCONTRO NACIONAL DE PESQUISA EM EDUCAÇÃO EM CIÊNCIAS, 6., 2007, Florianópolis. Atas... Florianópolis: Associação Brasileira de Pesquisa em Educação em Ciências, 2007. CD-ROM. 
TERRAZZAN, E. A.; GABANA, M. Um estudo sobre o uso de atividade didática com texto de divulgação científica em aulas de física. In:

ENCONTRO NACIONAL DE PESQUISA EM EDUCAÇÃO EM CIÊNCIAS, 4., 2003, Bauru. Atas... Bauru: Associação Brasileira de Pesquisa em Educação em Ciências, 2003. CD-ROM.

UCHÔA, C. M. A.; SANTOS, S. P.; ARAÚJO, R. C. E. P.; AZEVEDO, A. C. P. Ciência em jornais diários: um estudo de caso de três publicações. In: ENCONTRO NACIONAL DE PESQUISA EM EDUCAÇÃO EM CIÊNCIAS, 5., 2005, Bauru. Atas... Bauru: Associação Brasileira de Pesquisa em Educação em Ciências, 2005. CD-ROM.

VALÉRIO, M. Os desafios da divulgação científica sob o olhar epistemológico de Gaston Bachelard. In: ENCONTRO NACIONAL DE PESQUISA EM EDUCAÇÃO EM CIÊNCIAS, 5., 2005, Bauru. Atas... Bauru: Associação Brasileira de Pesquisa em Educação em Ciências, 2005. CD-ROM.

VÁZQUEZ-ALONSO, A; ACEVEDO-DIAZ, J. A.; MAS, M. A. M. Más allá de la enseñanza de las ciencias para científicos: hacia una educación científica humanística. Revista Electrónica de Enseñanza de las Ciências, v. 4, n. 2, p. 68-97, 2005.

ZAMBON, L. B.; TERRAZZAN, E. A. Estudo sobre o uso de analogias em revista de divulgação científica. In: ENCONTRO NACIONAL DE PESQUISA EM EDUCAÇÃO EM CIÊNCIAS, 6., 2007, Florianópolis. Atas... Florianópolis: Associação Brasileira de Pesquisa em Educação em Ciências, 2007. CD-ROM.

ZAMBONI, L. M. S. Cientistas, jornalistas e a divulgação científica: subjetividade e heterogeneidade no discurso da divulgação científica. Campinas: Autores Associados, 2001. 167 p.

ZANON, D. A. V.; ALMEIDA, M. J. P. M.; QUEIROZ, S. L. Contribuições da leitura de um texto de Bruno Latour e Steve Woolgar para a formação de estudantes em um curso superior de química. Revista Electrónica de Enseñanza de las Ciencias, v. 6, n. 1, p. 56-69, 2007.

ZUCCO, C.; PESSINE, F. B. T.; ANDRADE, J. B. Diretrizes curriculares para os cursos de química. Química Nova, v. 22, n. 3, p. 454-461, 1999.

WHELAN, R. J.; ZARE, R. N. Teaching effective communication in a writing-intensive analytical chemistry course. Journal of Chemical Education, v. 80, n. 8, p. 904-906, 2003. 


\section{APÊNDICE A}

Trabalhos localizados a partir da revisão bibliográfica realizada no periódico Journal of Chemical Education (1988- julho/2008) e nos trabalhos apresentados nos Encontros Nacionais de Pesquisa em Educação em Ciências (1997-2007), Encontros Nacionais de Ensino de Quimica, Encontros de Debates sobre o Ensino de Quimica e Reuniões Anuais da Sociedade Brasileira de Quimica (1999-2007).

1997

ALMEIDA, M. J. P. M. Questões formuladas e representações de alunos e professores na leitura de textos de divulgação científica. In: ENCONTRO NACIONAL DE PESQUISA EM EDUCAÇÃO EM CIÊNCIAS, 1., 1997, Águas de Lindóia. Atas... Águas de Lindóia: Associação Brasileira de Pesquisa em Educação em Ciências, 1997. CD-ROM.

COMEFORD, L. Writing assignments in physical chemistry. Journal of Chemical Education, v. 74, n. 4, p. 392, 1997.

1999

SALÉM, S.; KAWAMURA, M. R. As perguntas dos leitores nas revistas de divulgação científica: possíveis contribuições ao ensino de fisica. In: ENCONTRO NACIONAL DE PESQUISA EM EDUCAÇÃO EM CIÊNCIAS, 2., 1999, Valinhos. Atas... Valinhos: Associação Brasileira de Pesquisa em Educação em Ciências, 1999. CD-ROM.

2001

CARROLL, F. A.; SEEMAN, J. I. Placing science into its human context: using scientific autobiography to teach chemistry. Journal of Chemical Education, v. 78, n. 12, p. 1618-1622, 2001.

CHAVES, T. V.; MEZZOMO, J.; TERRAZZAN, E. A. Textos de divulgação científica como recurso didático para o ensino-aprendizagem da física clássica: exemplos em termodinâmica e eletromagnetismo. In: ENCONTRO NACIONAL DE PESQUISA EM EDUCAÇÃO EM CIÊNCIAS, 3., 2001, Atibaia. Atas... Atibaia: Associação Brasileira de Pesquisa em Educação em Ciências, 2001a. CD-ROM.

CHAVES, T. V.; MEZZOMO, J.; TERRAZZAN, E. A. Textos de divulgação científica como recurso didático para o ensino-aprendizagem da física moderna: um exemplo em relatividade. In: ENCONTRO NACIONAL DE PESQUISA EM EDUCAÇÃO EM CIÊNCIAS, 3., 2001, Atibaia. Atas... Atibaia: Associação Brasileira de Pesquisa em Educação em Ciências, 2001b. CD-ROM. 
CHAVES, T. V.; MEZZOMO, J.; TERRAZZAN, E. A. Avaliando práticas didáticas de utilização de textos de divulgação científica como recurso didático em aulas de física no ensino médio. In: ENCONTRO NACIONAL DE PESQUISA EM EDUCAÇÃO EM CIÊNCIAS, 3., 2001, Atibaia. Atas... Atibaia: Associação Brasileira de Pesquisa em Educação em Ciências, 2001c. CD-ROM.

DYBOWSKI, C. A course in the history of physical chemistry with an emphasis on writing. Journal of Chemical Education, v. 78, n. 12, p. 1623-1625, 2001.

GOUVÊA, G.; BARROS, H. L. Transformação do texto científico em texto de divulgação: o caso da ciência hoje das crianças. In: ENCONTRO NACIONAL DE PESQUISA EM EDUCAÇÃO EM CIÊNCIAS, 3., 2001, Atibaia. Atas... Atibaia: Associação Brasileira de Pesquisa em Educação em Ciências, 2001. CD-ROM.

MARTINS, I.; ANDRADE, I.; TRIGO, E.; ROCHA, M. B.; CRUZ, U. M.; ROCHA, A. D. Divulgação científica na sala de aula: as escolhas dos professores. In: ENCONTRO NACIONAL DE PESQUISA EM EDUCAÇÃO EM CIÊNCIAS, 3., 2001, Atibaia. Atas... Atibaia: Associação Brasileira de Pesquisa em Educação em Ciências, 2001. CD-ROM.

MARTINS, I.; CASSAB, M.; ROCHA, M. B. Análise do processo de re-elaboração discursiva de um texto de divulgação científica para um texto didático. In: ENCONTRO NACIONAL DE PESQUISA EM EDUCAÇÃO EM CIÊNCIAS, 3., 2001, Atibaia. Atas... Atibaia: Associação Brasileira de Pesquisa em Educação em Ciências, 2001. CD-ROM.

ROCHA, M. B.; MARTINS, I. O professor e a divulgação científica na sala de aula. In: ENCONTRO NACIONAL DE PESQUISA EM EDUCAÇÃO EM CIÊNCIAS, 3., 2001, Atibaia. Atas... Atibaia: Associação Brasileira de Pesquisa em Educação em Ciências, 2001. CD-ROM.

2003

AIRES, J. A.; BOER, N.; BRANDT, C. F.; FERRARI, N.; GOMES, M. G.; OLIVEIRA, V. L. B.; PAZ, A. M.; PINHEIRO, N. A. M.; SCHEID, N. M. J. Divulgação científica na sala de aula: um estudo sobre a contribuição da revista ciência hoje das crianças. In: ENCONTRO NACIONAL DE PESQUISA EM EDUCAÇÃO EM CIÊNCIAS, 4., 2003, Bauru. Atas... Bauru: Associação Brasileira de Pesquisa em Educação em Ciências, 2003. CD-ROM.

CABRAL, C. G. Espelho, espelho meu: a clonagem num livro de divulgação cientifica. In: ENCONTRO NACIONAL DE PESQUISA EM EDUCAÇÃO EM CIÊNCIAS, 4., 2003, Bauru. Atas... Bauru: Associação Brasileira de Pesquisa em Educação em Ciências, 2003. CD-ROM. 
COSTA, A. P. B.; CORREA, A. L. L.; NASCIMENTO, S. S. A multimodalidade no discurso da divulgação científica. In: ENCONTRO NACIONAL DE PESQUISA EM EDUCAÇÃO EM CIÊNCIAS, 4., 2003, Bauru. Atas... Bauru: Associação Brasileira de Pesquisa em Educação em Ciências, 2003. CD-ROM.

CUSTÓDIO, J. F.; RICARDO, E. C. Divulgação científica e indústria cultural: considerações acerca de uma semiformação. In: ENCONTRO NACIONAL DE PESQUISA EM EDUCAÇÃO EM CIÊNCIAS, 4., 2003, Bauru. Atas... Bauru: Associação Brasileira de Pesquisa em Educação em Ciências, 2003. CD-ROM.

FERREIRA, M. Temáticas superinteressantes na mídia e temas transversais na educação em uma análise cultural. In: ENCONTRO NACIONAL DE PESQUISA EM EDUCAÇÃO EM CIÊNCIAS, 4., 2003, Bauru. Atas... Bauru: Associação Brasileira de Pesquisa em Educação em Ciências, 2003. CD-ROM.

GABANA, M.; LUNARDI, G.; TERRAZZAN, E. A. Textos de divulgação científica: avaliando uma estratégia didática para o ensino médio. In: ENCONTRO NACIONAL DE PESQUISA EM EDUCAÇÃO EM CIÊNCIAS, 4., 2003, Bauru. Atas... Bauru: Associação Brasileira de Pesquisa em Educação em Ciências, 2003. CD-ROM.

MARANDINO, M.; SILVEIRA, R. V. M.; CHELINI, M. J.; FERNANDES, A. B.; RACHID, V.; MARTINS, L. C.; LOURENÇO, M. F.; FERNANDES, J. A.; FLORENTINO, H. A. A educação não formal e a divulgação científica: o que pensa quem faz. In: ENCONTRO NACIONAL DE PESQUISA EM EDUCAÇÃO EM CIÊNCIAS, 4., 2003, Bauru. Atas... Bauru: Associação Brasileira de Pesquisa em Educação em Ciências, 2003. CD-ROM.

MONTEIRO, M. A.; MONTEIRO, I. C. C.; GASPAR, A. Textos de divulgação científica em sala de aula para o ensino de física. In: ENCONTRO NACIONAL DE PESQUISA EM EDUCAÇÃO EM CIÊNCIAS, 4., 2003, Bauru. Atas... Bauru: Associação Brasileira de Pesquisa em Educação em Ciências, 2003. CD-ROM.

PEREIRA, M. C.; PINTO NETO, P. C. O uso da revista Superinteressante nas aulas de química. Existe alguma inovação? In: ENCONTRO NACIONAL DE PESQUISA EM EDUCAÇÃO EM CIÊNCIAS, 4., 2003, Bauru. Atas... Bauru: Associação Brasileira de Pesquisa em Educação em Ciências, 2003. CD-ROM.

PEREZ, J. R. B.; CALUZI, J. J. A divulgação científica e as distorções conceituais do invariante massa-energia relativístico. In: ENCONTRO NACIONAL DE PESQUISA EM EDUCAÇÃO EM CIÊNCIAS, 4., 2003, Bauru. Atas... Bauru: Associação Brasileira de Pesquisa em Educação em Ciências, 2003. CD-ROM. 
SILVA, L. L.; TERRAZZAN, E. A. As analogias na divulgação científica: o caso da ciência hoje das crianças. In: ENCONTRO NACIONAL DE PESQUISA EM EDUCAÇÃO EM CIÊNCIAS, 4., 2003, Bauru. Atas... Bauru: Associação Brasileira de Pesquisa em Educação em Ciências, 2003. CD-ROM.

TERRAZZAN, E. A.; GABANA, M. Um estudo sobre o uso de atividade didática com texto de divulgação científica em aulas de física. In: ENCONTRO NACIONAL DE PESQUISA EM EDUCAÇÃO EM CIÊNCIAS, 4., 2003, Bauru. Atas... Bauru: Associação Brasileira de Pesquisa em Educação em Ciências, 2003. CD-ROM.

2004

CHAGAS, P.; BARBOSA, E. A.; NAVEGA, E. A. Analfabetismo científico e a mídia: estratégias de integração interdisciplinar. In: ENCONTRO NACIONAL DE ENSINO DE QUÍMICA, 12., 2004, Goiânia. Anais... Goiânia: Sociedade Brasileira de Química, 2004. ref. ENEQ-120.

FIELD'S, K. A. P.; RASTRELO, M. R. O uso de artigos eletrônicos para o ensino de forças intermoleculares para alunos do curso de biologia. In: ENCONTRO NACIONAL DE ENSINO DE QUÍMICA, 12., 2004, Goiânia. Anais... Goiânia: Sociedade Brasileira de Química, 2004. ref. ENEQ-187.

LINDINO, C. A.; CUNHA, M. B. Divulgação científica através de textos em jornal. In: ENCONTRO NACIONAL DE ENSINO DE QUÍMICA, 12., 2004, Goiânia. Anais... Goiânia: Sociedade Brasileira de Química, 2004. ref. ENEQ-064.

2005

AMORIM, L. M.; MASSARANI, L. Jornalismo científico: um estudo de caso de três jornais brasileiros. In: ENCONTRO NACIONAL DE PESQUISA EM EDUCAÇÃO EM CIÊNCIAS, 5., 2005, Bauru. Atas... Bauru: Associação Brasileira de Pesquisa em Educação em Ciências, 2005. CD-ROM.

BROTERO, P. P.; MARCONDES, M. E. R. Análise do discurso na divulgação científica - um caso de química. In: ENCONTRO NACIONAL DE PESQUISA EM EDUCAÇÃO EM CIÊNCIAS, 5., 2005, Bauru. Atas... Bauru: Associação Brasileira de Pesquisa em Educação em Ciências, 2005. CD-ROM.

CAMPOS, P. T.; FONSECA, C. S.; DUARTE, A. T.; LAMEIRO, M. G. S. Diário metálico. In: ENCONTRO DE DEBATES SOBRE O ENSINO DE QUÍMICA, 25., 2005, Ijuí. Anais... Ijuí: Unijuí, 2005. CD-ROM.

FERRARI, P. C.; ANGOTTI, J. A.; CRUZ, F. F. S. A divulgação científica na educação escolar: discutindo um exemplo. In: ENCONTRO NACIONAL DE PESQUISA EM EDUCAÇÃO EM CIÊNCIAS, 5., 2005, Bauru. Atas... Bauru: Associação Brasileira de Pesquisa em Educação em Ciências, 2005. CD-ROM. 
FERRARI, P. C.; ANGOTTI, J. A.; TRAGTENBERG, M. H. R. Utilização de textos de divulgação científica sobre a teoria do caos na educação. In: ENCONTRO NACIONAL DE PESQUISA EM EDUCAÇÃO EM CIÊNCIAS, 5., 2005, Bauru. Atas... Bauru: Associação Brasileira de Pesquisa em Educação em Ciências, 2005. CD-ROM.

GOLDBACH, T.; EL-HANI, C.; MARTINS, R. C. Idéias sobre genes em revistas de divulgação científica e em glossários virtuais. In: ENCONTRO NACIONAL DE PESQUISA EM EDUCAÇÃO EM CIÊNCIAS, 5., 2005, Bauru. Atas...

Bauru: Associação Brasileira de Pesquisa em Educação em Ciências, 2005. CD-ROM.

MIRANDA, A. S. Superinteressante: das bancas para a escola. In: ENCONTRO NACIONAL DE PESQUISA EM EDUCAÇÃO EM CIÊNCIAS, 5., 2005, Bauru. Atas... Bauru: Associação Brasileira de Pesquisa em Educação em Ciências, 2005. CD-ROM.

NASCIMENTO, T. G.; SOUZA, S. C. A produção sobre divulgação científica em eventos de ensino de ciências: vislumbrando tendências. In: ENCONTRO NACIONAL DE PESQUISA EM EDUCAÇÃO EM CIÊNCIAS, 5., 2005, Bauru. Atas... Bauru: Associação Brasileira de Pesquisa em Educação em Ciências, 2005. CD-ROM.

OSORIO, V. K. L.; PORTO, P. A.; TIEDEMANN, P. W.; CORIO, P. Primo Levi e A Tabela Periódica: explorando possibilidades didáticas de um texto literário. In: REUNIÃO ANUAL DA SOCIEDADE BRASILEIRA DE QUÍMICA, 28., 2005, Poços de Caldas. Anais... Poços de Caldas: Sociedade Brasileira de Química 2005. CD-ROM.

RIBEIRO, R. A.; KAWAMURA, M. R. A ciência em diferentes vozes: uma análise de textos de divulgação científica. In: ENCONTRO NACIONAL DE PESQUISA EM EDUCAÇÃO EM CIÊNCIAS, 5., 2005, Bauru. Atas... Bauru: Associação Brasileira de Pesquisa em Educação em Ciências, 2005. CD-ROM.

SAMET, C.; HIGGINS, P. J. Napoleon's buttons: teaching the role of chemistry in history. Journal of Chemical Education, v. 82, n. 10, p. 1496-1500, 2005.

STRACK, R. LOGUERCIO. R. C.; DEL PINO, J. C. Os conceitos estruturantes da literatura de divulgação científica como contribuição ao perfil conceitual químico dos alunos. In: ENCONTRO DE DEBATES SOBRE O ENSINO DE QUÍMICA, 25., 2005, Ijuí. Anais... Ijuí: Unijuí, 2005. CD-ROM.

UCHÔA, C. M. A.; SANTOS, S. P.; ARAÚJO, R. C. E. P.; AZEVEDO, A. C. P. Ciência em jornais diários: um estudo de caso de três publicações. In:

ENCONTRO NACIONAL DE PESQUISA EM EDUCAÇÃO EM CIÊNCIAS, 5., 2005, Bauru. Atas... Bauru: Associação Brasileira de Pesquisa em Educação em Ciências, 2005. CD-ROM. 
VALÉRIO, M. Os desafios da divulgação científica sob o olhar epistemológico de Gaston Bachelard. In: ENCONTRO NACIONAL DE PESQUISA EM EDUCAÇÃO EM CIÊNCIAS, 5., 2005, Bauru. Atas... Bauru: Associação Brasileira de Pesquisa em Educação em Ciências, 2005. CD-ROM.

2006

BROTERO, P. P.; MARCONDES, M. E. R. Uso de texto de divulgação científica no ensino de química no ensino médio - um estudo de discursos. In: ENCONTRO NACIONAL DE ENSINO DE QUÍMICA, 13., 2006, Campinas. Anais... Campinas: Sociedade Brasileira de Química, 2006. CD-ROM.

CUNHA, M. B.; GIORDAN, M. A mídia e o conhecimento químico. In: ENCONTRO NACIONAL DE ENSINO DE QUÍMICA, 13., 2006, Campinas. Anais... Campinas: Sociedade Brasileira de Química, 2006. CD-ROM.

QUEIROZ, S. L.; SÁ, L. P. Identificação de termos argumentativos em artigos de divulgação científica por alunos de graduação em química. In:

ENCONTRO DE DEBATES SOBRE O ENSINO DE QUÍMICA, 26., 2006, Santa Cruz do Sul. Anais... Santa Cruz do Sul: UNISC, 2006. CD-ROM.

RIBEIRO, M. H. O.; COSTA NETO, J. J. G.; PESSOA, P. A. P.; SILVA, H. R.; SIQUEIRA, L. F. S.; LOPES, R. B.; SANTOS, H. C. C.; FARIAS, T. M.; CARVALHO, R. C. S.; RANGEL, J. H. G.; OLIVEIRA, M. M. O uso de um jornal como uma maneira multidisciplinar e divertida de se aprender a química. In: ENCONTRO NACIONAL DE ENSINO DE QUÍMICA, 13., 2006, Campinas. Anais... Campinas: Sociedade Brasileira de Química, 2006. CD-ROM.

SOARES, A. V.; OLIVEIRA, O. M. M. F. Jornalismo científico aplicado ao processo de aprendizagem. In: ENCONTRO NACIONAL DE ENSINO DE QUÍMICA, 13., 2006, Campinas. Anais... Campinas: Sociedade Brasileira de Química, 2006. CD-ROM.

STRACK, R. LOGUERCIO. R. C.; DEL PINO, J. C. A literatura de divulgação científica como recurso didático na estrutura da matéria. In: ENCONTRO NACIONAL DE ENSINO DE QUÍMICA, 13., 2006, Campinas. Anais... Campinas: Sociedade Brasileira de Química, 2006a. CD-ROM.

STRACK, R. LOGUERCIO. R. C.; DEL PINO, J. C. Uma autobiografia e o conhecimento químico: as possiveis contribuições do livro 'Tio Tungstênio' às aulas de química. In: REUNIÃO ANUAL DA SOCIEDADE BRASILEIRA DE QUÍMICA, 29., 2006, Águas de Lindóia. Anais... Águas de Lindóia: Sociedade Brasileira de Química, 2006b. CD-ROM. 
ABREU, L. N.; MASSI, L.; QUEIROZ, S. L. Textos de divulgação científica no ensino superior de Química. In: ENCONTRO NACIONAL DE PESQUISA EM EDUCAÇÃO EM CIÊNCIAS, 6., 2007, Florianópolis. Atas... Florianópolis: Associação Brasileira de Pesquisa em Educação em Ciências, 2007. CD-ROM.

BINSFELD, S. S.; ZANON, L. B. A participação de materiais de divulgação científica no desenvolvimento de uma situação de estudo no ensino médio. In: REUNIÃO ANUAL DA SOCIEDADE BRASILEIRA DE QUÍMICA, 30., 2007, Águas de Lindóia. Anais... Águas de Lindóia: Sociedade Brasileira de Química, 2007. CD-ROM.

GALAGOVSKY, L.; CUÑADO, C.; PALMIÉRI, L. J. QUEIROZ, S. L. Textos de divulgação científica no ensino-aprendizagem dos tópicos "Combustão" e "Tabela Periódica”. In: REUNIÃO ANUAL DA SOCIEDADE BRASILEIRA DE QUÍMICA, 30., 2007, Águas de Lindóia. Anais... Águas de Lindóia: Sociedade Brasileira de Química, 2007. CD-ROM.

GOMES, M. C.; DA POIAN, A. T.; GOLDBACH, T. Revistas de divulgação científica: concepções sobre os temas alimentação-metabolismo energético. In: ENCONTRO NACIONAL DE PESQUISA EM EDUCAÇÃO EM CIÊNCIAS, 6., 2007, Florianópolis. Atas... Florianópolis: Associação Brasileira de Pesquisa em Educação em Ciências, 2007. CD-ROM.

IANINI, A. M. N.; FARES, D. C.; BIZERRA, A.; MARANDINO, M. Pesquisa em divulgação científica: um levantamento de referenciais teóricos nacionais. In: ENCONTRO NACIONAL DE PESQUISA EM EDUCAÇÃO EM CIÊNCIAS, 6., 2007, Florianópolis. Atas... Florianópolis: Associação Brasileira de Pesquisa em Educação em Ciências, 2007. CD-ROM.

KEMPER, A.; ZIMMERMANN, E.; GASTAL, M. L. A. Conceitos de evolução na revista superinteressante. In: ENCONTRO NACIONAL DE PESQUISA EM EDUCAÇÃO EM CIÊNCIAS, 6., 2007, Florianópolis. Atas... Florianópolis: Associação Brasileira de Pesquisa em Educação em Ciências, 2007. CD-ROM.

LEGEY, C.; COUTINHO, C. M. L. M. Divulgação de biologia celular através da mídia impressa brasileira - estudo de caso de dois jornais e três revistas. In: ENCONTRO NACIONAL DE PESQUISA EM EDUCAÇÃO EM CIÊNCIAS, 6., 2007, Florianópolis. Atas... Florianópolis: Associação Brasileira de Pesquisa em Educação em Ciências, 2007. CD-ROM.

MENEGAT, T. M. C.; ClEMENT, L.; TERRAZZAN, E. A. Textos de divulgação cientifica em aulas de física: uma abordagem investigativa. In: ENCONTRO NACIONAL DE PESQUISA EM EDUCAÇÃO EM CIÊNCIAS, 6., 2007, Florianópolis. Atas... Florianópolis: Associação Brasileira de Pesquisa em Educação em Ciências, 2007. CD-ROM. 
NASCIMENTO, T. G.; SOUZA, S. C. Modos de leitura de textos de divulgação científica. In: ENCONTRO NACIONAL DE PESQUISA EM EDUCAÇÃO EM CIÊNCIAS, 6., 2007, Florianópolis. Atas... Florianópolis: Associação Brasileira de Pesquisa em Educação em Ciências, 2007. CD-ROM.

OSORIO, V. K. L.; TIEDEMANN, P. W.; PORTO, P. A. Primo Levi and The Periodic Table: teaching chemistry using a literary text. Journal of Chemical Education, v. 84, n. 5, p. 775-778, 2007.

PRESTES, R. F.; SILVA, A. M. M. Artigos de divulgação científica para o estudo de problemas energéticos com enfoque CTS. In: ENCONTRO NACIONAL DE PESQUISA EM EDUCAÇÃO EM CIÊNCIAS, 6., 2007, Florianópolis. Atas... Florianópolis: Associação Brasileira de Pesquisa em Educação em Ciências, 2007. CD-ROM.

PUIATI, L. L.; BOROWSKY, H. G.; TERRAZZAN, E. A. O texto de divulgação científica como recurso para o ensino de ciências na educação básica: um levantamento das produções nos enpec. In: ENCONTRO NACIONAL DE PESQUISA EM EDUCAÇÃO EM CIÊNCIAS, 6., 2007, Florianópolis. Atas... Florianópolis: Associação Brasileira de Pesquisa em Educação em Ciências, 2007. CD-ROM.

STRACK, R. LOGUERCIO. R. C.; DEL PINO, J. C. Linguagem e interpretações de professores universitários sobre literatura de divulgação científica. In: ENCONTRO NACIONAL DE PESQUISA EM EDUCAÇÃO EM CIÊNCIAS, 6., 2007, Florianópolis. Atas... Florianópolis: Associação Brasileira de Pesquisa em Educação em Ciências, 2007. CD-ROM.

ZAMBON, L. B.; TERRAZZAN, E. A. Estudo sobre o uso de analogias em revista de divulgação científica. In: ENCONTRO NACIONAL DE PESQUISA EM EDUCAÇÃO EM CIÊNCIAS, 6., 2007, Florianópolis. Atas... Florianópolis: Associação Brasileira de Pesquisa em Educação em Ciências, 2007. CD-ROM. 


\section{APÊNDICE B}

\section{Questionário de Caracterização}

Prezado(a) aluno(a),

Por favor, responda com atenção cada uma das questões abaixo

\section{Nome completo:}

\section{Idade:}

\section{Cidade/Estado de Origem:}

\section{BLOCO 1}

1) Quantos livros você lê, em média, por ano? ( ) menos de 1; ( ) 1 a 3; ( ) 3 a 6; ) mais de 6.

2) No seu cotidiano, você lê mais freqüentemente: ( ) livros ( ) jornais ( ) revistas ( ) outros. Quais?

3) Você tem interesse por trabalhos relacionados à Ciência (divulgação de novas descobertas, aspectos históricos, formas de produção, etc.)? Se sim, quais tipos de trabalhos dessa natureza você já leu? Lembre de algum que tenha chamado a sua atenção?

4) A produção e a divulgação do conhecimento científico envolvem diversas formas de comunicação. Algumas delas estão citadas abaixo. Assinale aquelas que você conhece:

( ) Artigos de divulgação científica; ( ) Livros didáticos de ciências; ( ) Relatórios de pesquisa; ( ) Artigos científicos; ( ) Trabalhos apresentados em reuniões científicas; ( ) Projetos de pesquisa; ( ) outros. Quais?

5) Você já participou de algum evento científico? Se sim, qual(is)?

\section{BLOCO 2}

1) Que gênero de leitura você prefere?

2) Na maioria das vezes, com que finalidade você lê?

3) Acha importante a leitura? Por quê? Você tem tempo para ler durante o dia?

4) Você assina ou lê, freqüentemente, alguma revista ou jornal? Se sim, qual(is)? Essa leitura representa alguma contribuição para você? Se sim, qual(is)?

5) Você lia revistas infantis? Relate brevemente as leituras mais marcantes que realizou na sua infância.

6) Já ganhou livro de presente? Qual(is)? Se não ganhou, o que sentiria se ganhasse?

7) Já deu livro a alguém? Qual(is)?

8) Quais os últimos livros que você leu?

9) Tem algum livro que você gostaria de ler, mas não leu? Por quê?

10) Há alguma coisa que você tenha lido e nunca mais tenha esquecido? Por que não esqueceu? Qual o título e o autor?

11) Você relê um texto/livro quando gosta dele? 
12) Você pára na banca de jornal para ler as manchetes do dia?

13) Gosta de escrever? Escreve o que e onde?

14) Quando vai estudar como é a sua relação com a leitura? Quando lê com outro propósito o faz da mesma maneira? 


\section{APENNDICE C}

Questionário sobre as impressões iniciais com relação à leitura dos textos

1. Você consegue estabelecer relações entre o que está dito no texto e seus conhecimentos adquiridos durante as aulas no IQSC, no ensino médio ou no seu dia-a-dia? Justifique a sua resposta da forma mais detalhada e clara possivel.

2. Quais são suas impressões sobre o texto? Que tipo de leitura você fez a partir dele (agradável, dificil, interessante etc.)?

3. Você já havia lido algum livro do Oliver Sacks? Conhece o autor? Se sim, em que situação entrou em contato com seu trabalho? 


\section{APÊNDICE D}

Questionário sobre as impressões dos alunos com relação à primeira atividade

1. Que aspectos do texto você considera que tenham relação com os assuntos apresentados nas aulas teóricas?

2. A leitura do texto contribuiu para um melhor entendimento em relação às aulas teóricas? Justifique a sua resposta.

3. Qual a sua opinião sobre a atividade realizada? Faça um breve comentário. 


\section{APENNDICE E}

Questionário sobre as impressões dos alunos com relação à segunda atividade

1. Que aspectos do texto você considera que tenham relação com os assuntos apresentados nas aulas teóricas?

2. A leitura do texto contribuiu para um melhor entendimento em relação às aulas teóricas? Justifique a sua resposta.

3. Qual a sua opinião sobre a atividade realizada? Faça um breve comentário.

4. Compare as dinâmicas de trabalho (textos do Tio Tungstênio) realizadas na primeira e segunda atividade. 


\section{APÊNDICE F}

\section{Solicitação da produção dos textos}

Produza um texto de gênero livre (narração, carta, poesia, diário etc.) dirigido a um leitor com as características de um calouro do curso de graduação em química. O texto deve tomar como base o capítulo Luz brilhante, capítulo 24 do livro Tio Tungstênio e as aulas ministradas na disciplina de Fundamentos de Química Estrutural. Faça uso de todos os recursos que você julgar necessários para produzir um texto que favoreça o entendimento do leitor sobre o conteúdo(s) de química nele apresentado(s). O texto é individual, deve ser escrito à mão e não existe limite máximo de espaço a ser ocupado pelo texto.

Produza um texto de gênero livre (narração, carta, poesia, diário etc.) dirigido a um leitor com as características de um calouro do curso de graduação em química. O texto deve tomar como base o capítulo O jardim de Mendeleiev, capítulo 16 do livro Tio Tungstênio e as aulas ministradas na disciplina de Fundamentos de Quimica Estrutural. Faça uso de todos os recursos que você julgar necessários para produzir um texto que favoreça o entendimento do leitor sobre o conteúdo(s) de química nele apresentado(s). O texto é individual, deve ser escrito à mão e não existe limite máximo de espaço a ser ocupado pelo texto. 


\section{APENDICE G}

\section{Questionário sobre as impressões dos alunos com relação à proposta de ensino.}

1. No decorrer do semestre, você realizou atividades em grupo que envolveram a leitura de alguns capítulos do livro Tio Tungstênio. Você já havia lido algum texto de divulgação científica (livro, artigo em revista ou jornal etc.) em sala de aula? Se sim, conte como esse processo foi conduzido pelo(a) professor(a) e com quais objetivos. Mencione o(s) texto(s) e quais foram as suas impressões a respeito da atividade e do(s) texto(s) lido(s).

2. Você já havia lido algum texto de divulgação científica (livro, artigo, texto de jornal etc.) sem a solicitação do professor. Ou seja, por opção sua? Se sim, mencione os critérios (ou aspectos que você leva em consideração) para a escolha do texto. Cite alguns exemplos de textos de divulgação escolhidos por você para leitura e quais são as razões /motivações que o (a) levam a fazer isto.

3. Com relação à leitura de alguns capitulos do livro Tio Tungstênio, realizada como atividade didática nesse semestre, responda:

a) $\mathrm{O}$ que você achou dos conteúdos e da forma como eles foram apresentados pelo autor nos capítulos que você leu? Emita sua opinião sobre todos os capítulos lidos, com destaque para o Luz brilhante e $O$ jardim de Mendeleiev.

b) Você acredita que a leitura e discussão dos capitulos Luz brilhante e $O$ jardim de Mendeleiev foram relevantes para o seu aprendizado na disciplina Fundamentos de Quimica Estrutural? Justifique a sua resposta (procure ser muito claro e detalhista na redação desta resposta; ela irá subsidiar atividades didáticas que serão programadas no futuro).

c) Se você respondeu positivamente à questão $\mathbf{b}$, tente estabelecer relações entre o que foi aprendido por você, a partir das aulas e da leitura do texto. $\mathrm{Ou}$ seja, mencione ocasiões em que as atividades de aula foram complementadas (ou acrescentadas) pela atividade de leitura.

d) Quais são as suas impressões a respeito do processo de realização das atividades (leitura em casa e na sala, formulação de perguntas, apresentação de perguntas desafio, tempo de realização da atividade etc.) com o livro Tio Tungstênio? Caso você acredite que elas podem ser aperfeiçoadas, por favor, apresente sugestões para tanto. As suas sugestões serão úteis para a organização de atividades futuras com textos de divulgação no IQSC. 
4. A atividade realizada com o livro Tio Tungstênio na disciplina Fundamentos de Quimica Estrutural, de alguma maneira, influenciou:

a) A sua habilidade de leitura e compreensão de textos de divulgação científica.

SIM ( ) NÃO ( ). Faça comentários sobre a sua resposta.

b) A sua habilidade de realização de trabalhos em grupo.

SIM ( ) NÃO ( ). Faça comentários sobre a sua resposta.

c) A sua habilidade de entendimento sobre a forma como a ciência é construída (ou seja, a forma como a pesquisa em química é realizada).

SIM ( ) NÃO ( ). Faça comentários sobre a sua resposta.

d) A sua habilidade de comunicação escrita e/ou oral.

SIM ( ) NÃO ( ). Faça comentários sobre a sua resposta.

5. Você gostaria de trabalhar novamente com textos de divulgação científica (livro, artigo em revista ou jornal, etc.) em outras disciplinas no IQSC? Justifique a sua resposta.

6- Se existem comentários que você deseja fazer (sobre o texto e/ou a atividade), que não foram inseridos no questionário, faça-os a seguir. 


\section{ANEXO A}

\section{Texto produzido pelo Aluno 1 referente ao capitulo Luz brilhante}

São Carlos, 1 de março de 2008.

Calouros,

Primeiramente, parabenizo muito a todos vocês pelo ingresso na Universidade de São Paulo, e mais ainda pela maravilhosa escolha do curso de Química!

Espero realmente que descubram, ou cultivem todo o encantamento pelo conjunto teórico das matérias que o curso pode oferecer. E para que vocês comecem a ter contato com a química, nada melhor do que falar sobre os elementos químicos. Como se formaram? Como foram organizados em uma tabela? Quem os organizou? Esses são alguns dos muitos questionamentos, que ao longo do curso serão solucionados, mas porque não solucionar pelo menos essas perguntas agora?

As respostas a seguir, será um resumo, perto do que verão durante as aulas teóricas, mas espero que eu introduza o assunto de forma a cativá-los e estimulá-los a querer saber sempre mais.

Comecemos a explicar que a Química é uma ciência que nasceu da curiosidade, necessidade e ambição do homem para entender e dominar a natureza; e é a ciência que estuda as transformações que envolvem matéria e energia.

Apesar de só ser reconhecida como ciência a partir do século XVIII, ela tem uma marca que sempre a caracterizou e identifica, desde seus primórdios, até os dias de hoje: a experimentação.

O objetivo de todo o químico é entender exatamente como as transformações ocorrem, conhecer os principios que regem as transformações para poder prever quando uma transformação é possivel ou não e quando sua reprodução em grande escala é viável.

Os principios que iremos aprender são frutos da observação e da experimentação que o homem vem acumulando a séculos, não são verdades absolutas e acabadas. Há muito ainda que observar, experimentar e descobrir.

Cessando as introduções, vamos às explicações dos questionamentos quanto aos elementos químicos, explicações estas conseguidas ao longo dos séculos XIX e XX.

Houveram, durante este tempo, várias tentativas de determinar como surgiram os elementos e quantos deles eram necessários para construir o universo.

Até 1815 eram conhecidos um pouco mais de cinqüenta elementos. E se a teoria de Dalton fosse válida, seriam um pouco mais de cinqüenta elementos diferentes necessários para construírem o universo.

William Prout, um físico londrino com interesse pela química, durante suas pesquisas, observou que os pesos atômicos eram aproximadamente números inteiros, sendo portanto todos múltiplos do peso atômico do 
hidrogênio. Com isso, Prout quis dizer que todos os elementos eram "oriundos" da condensação do hidrogênio. Porém alguns elementos possuem pesos atômicos fracionários (por exemplo o cloro, com peso atômico 35,5), e foi por isso que a hipótese proposta por Prout apresentou dificuldades de ser sustentada especialmente quando Mendeleiev elaborou a tabela periódica.

Era necessário, acharem alguma propriedade que tirasse esse impasse de organizar a tabela periódica utilizando os pesos atômicos dos elementos. E foi Harry Moseley, um brilhante físico que trabalhava com Rutherford, o grande responsável pela descoberta dessa nova propriedade.

Moseley bombardeou diversos elementos com raios catódicos, fazendo com que emitissem raios $\mathrm{X}$ característicos, depois marcou em um gráfico as raízes quadradas das freqüências em relação ao número atômico dos elementos e obteve uma reta; marcando os pontos do modo inverso, ele demonstrou que o aumento na freqüência indicava passos nítidos e discretos ou saltos quando ele passava de um elemento ao seguinte. A partir disso Moseley julgou que a propriedade fundamental era a carga nuclear. Fora então resolvido o impasse!

Além dos números atômicos estabeleceram a seqüência ordinal dos elementos segundo seu peso atômico, eles indicam as cargas nucleares, as identidades dos elementos, de um modo absoluto e certo.

Vocês devem estar se perguntando, se tudo já estava determinado depois dessa descoberta. Se enganam os que pensaram que sim, pelo contrário, foi depois dessa descoberta que começaram a surgir os "por quês".

O modelo atômico de Rutherford, aquele que vocês viram no ensino médio, estava cada vez mais caindo em desuso, pois pelo que tudo indicava eram os elétrons os responsáveis pelas propriedades químicas dos elementos e também por muitas propriedades físicas.

Então, Niels Bohr, que também trabalhava no laboratório de Rutherford, utilizou a teoria dos quanta de Planck para contornar as impossibilidades do átomo de Rutherford, e elaborou uma nova teoria (acredito que esses postulados já sejam conhecidos de vocês). É importante salientar que conforme aumentava o número atômico, à medida que aumentava a carga nuclear, um número igual de elétrons tinha de ser acrescentado para manter a neutralidade do átomo. Mas essa distribuição de elétrons, segundo Bohr, seria feita de maneira que os elétrons ocupariam primeiro a órbita de menor energia, depois as seguintes (sempre em ordem crescente de energia).

As camadas de Bohr correspondiam aos períodos da tabela periódica de Mendeleiev (veja você mesmo: a primeira camada, como o primeiro período acomoda dois elétrons e dois elementos respectivamente).

Essa formação recebe o nome de aufbau, e por meio dela Bohr pensava que todos os elementos se inseririam naturalmente em seus lugares apropriados na tabela periódica.

Assim, a posição de cada elemento em seus átomos, e a reatividade e ligações de cada elemento podiam agora ser vistas sob o aspecto eletrônico, conforme o preenchimento da camada externa de elétrons, os chamados elétrons de valência. 
A tabela periódica eletrônica de Bohr, baseada na estrutura atômica, era essencialmente igual à tabela periódica empírica de Mendeleiev, baseada na reatividade química.

De forma resumida, o caráter e a identidade dos elementos, ou, enfim, doa parte desse caráter e identidade, agora podiam ser inferidos a partir de seus números atômicos, que não mais indicavam apenas a carga nuclear, mas representavam a própria arquitetura de cada átomo.

Poderiamos ficar páginas e mais páginas discorrendo sobre todas as descobertas, sobre os métodos utilizados para descobri-las, sobre o grau de importância e utilização das mesmas, porém acho que isso tenha sido o suficiente, pelo menos por hora.

Espero que tenha introduzido de maneira satisfatória esse tema, é óbvio que existem muito mais detalhes e peculiaridades sobre isso, e além disso, não pára por aí, mas como disse é apenas um resumo, espero ainda que tenha despertado a curiosidade de vocês de saberem mais sobre o tema.

Sejam todos bem-vindos à nossa Universidade! 


\title{
ANEXO B
}

\section{Texto produzido pelo Aluno 2 referente ao capitulo Luz brilhante}

\author{
O universo da química
}

O universo da química é muito rico e a medida que nós aprendemos novos assuntos de como tudo começou e foi desenvolvido, aumenta muito mais a curiosidade sobre como as coisas funcionam, ou mesmo o porque acontece desse jeito.

De quantos elementos Deus precisaria para construir o universo: Até 1815 apenas conhecia-se 50 elementos diferentes e hoje esse número aumentou muito e estão organizados em uma tabela periódica, de acordo com o número atômico de cada elemento. Mas o que seria número atômico e qual sua importância?

Respostas para tais perguntas parecem simples no contexto atual, mas há alguns séculos atrás essas questões eram um impasse muito grande, que fizeram do século XIX um século de dificuldades para os químicos e fisicos.

$\mathrm{Na}$ descoberta que o número atômico era uma característica única de cada elemento, foi algo completamente revolucionário para os cientistas, tudo isso foi possível graças ao brilhante Moseley. Como esse conseguiu tais resultados em poucos meses, muitos químicos que trabalhavam há anos na área, o acharam muito prepotente em excluir a possibilidade de descobrir novos elementos, além dos que ele indicara.

Mais tarde Moseley foi reconhecido por um dos maiores químicos da época: Urbain.

Depois de várias descobertas no mundo científico, sabe-se que estas estão longe de chegar ao fim.

Outro impasse para a época, foi determinar a órbita dos elétrons. Parecia algo impossivel de se determinar e na verdade até hoje é uma questão em pauta, a tentativa de criar métodos para se determinar a localização exata de um elétron sem interferir em seu curso, mas muito se evoluiu nesses estudos com a teoria dos quanta desenvolvida por Max Planck. Foi Niels Bohr que fez a ligação entre as descobertas de Rutherforf e Planck e concluiu que um átomo poderia ter um elétron em órbita, para sempre sem perder ou ganhar energia. Tempos depois com o surgimento da teoria da incerteza pode-se determinar a probabilidade de se encontrar um elétron em determinado espaço e tempo.

Saindo da discussão de elétrons, átomos, existem ainda inúmeras curiosidades no mundo químico.

Por exemplo, porque no laboratório a mistura de dois líquidos translúcidos pode adquirir cores escuras e diferentes? Por que existem materiais que podem conduzir corrente elétrica e outras não?

Se pararmos para pensar em nosso dia-a-dia, retiramos milhares de curiosidades a serem saciadas, pesquisando e logo você descobrirá que não existe um mundo sem relacionar com a química, pois mesmo as coisas mais 
medíocres, até as mais complexas, são construídas e/ou formadas a partir de átomos, formando moléculas.

Também é impressionante como cada novas descobertas e invenções surgem para facilitar nossas vidas e ajudam desde utilidades em casa como fonte de cura para doenças terminais, ajudando e auxiliando nosso dia-a-dia, despertando cada vez mais o espírito de pesquisar e descobrir. 


\section{ANEXO C}

\section{Texto produzido pelo Aluno 2 referente ao capítulo 0 jardim de Mendeleiev}

Um texto descontraído que mostra conceitos químicos relacionados com o dia-a-dia é muito importante para facilitar o entendimento de inúmeras coisas, dentro do universo da química.

Para pessoas como nós, amantes da química é super interessante ler textos como os do livro tio tungstênio.

Neste livro há um capítulo com o nome de jardim de Mendeleiev onde esse cita uma enorme tabela periódica, localizando nessa as propriedades e formas dos metais e não metais, introduz de maneira simplista conceitos de metais alcalinos, alcalinos terrosos, halogênios, peso atômico, dentro da tabela periódica.

Imagine que interessante poder visitar um museu onde se encontra uma gigante tabela periódica!

Juntando seus conhecimentos adquiridos em suas aulas de química estrutural, com os questionamentos feitos no livro, você poderá perceber o quão importante é o conteúdo ministrado tanto no livro e na disciplina na nossa vida.

Você já se perguntou porque a tabela periódica foi organizada dessa maneira? Porque a tabela começa com o hidrogênio ou porque mesmo dentro de categorias como por exemplo os metais precisam ser colocados exatamente da forma proposta?

Para solucionar as questões acima existem conceitos muito importantes denominados valência e peso atômico.

A valência foi um termo desenvolvido no final de 1850. A valência nada mais é que os elétrons que estão localizados na última camada, mas muito mais que isso. São os elétrons que exigem uma menor energia para formarem ligações químicas. Mendeleiev foi um dos primeiros a aproveitar esse conceito para auxiliá-la a organizar a classificação de sua tabela.

Por exemplo, os metais alcalinos do grupo $1 \mathrm{~A}$ possuem valência 1 , os alcalinos terrosos do grupo $2 \mathrm{~A}$ possuem valência $2 \mathrm{e}$ assim por diante.

$\mathrm{O}$ conceito de peso atômico introduzido por Dalton foi uma descoberta muito importante, uma vez que esse descobriu que o peso atômico era uma característica única de cada elemento.

Mendeleiev estudou em São Petersburgo e era uma pessoa muito curiosa e fanática por princípios organizadores. Foram muitos anos de pesquisa e dedicação para que ele conseguisse organizar os elementos da tabela periódica com uma lógica. Ele começou com a construção de uma pequena tabela que deveria ser ampliada em todos os sentidos.

Num certo dia ele teve um sonho, sonhou com uma imensa tabela periódica e ao acordar colocou o que sonhara num papel, reorganizou alguns elementos que julgava estar em lugar errado e com muita audácia Mendeleiev ainda deixou lugares vazios em sua tabela para colocar elementos que ainda eram desconhecidos e aos poucos com o descobrimento de novos elementos, outros cientistas foram percebendo que esses se 
encaixavam nos espaços vazios deixados na tabela de Mendeleiev e com poucos ajustes abriam espaços para outros elementos.

A partir disso Mendeleiev deixou de ser apenas um teórico sonhador para ser considerado descobridor das leis básicas da natureza. 


\section{ANEXO D}

\section{Texto produzido pelo Aluno 3 referente ao capitulo Luz brilhante}

Querido diário,

Hoje, dia 5 de março de 2007 tive uma das aulas mais interessantes sobre o curso de química, da área bacharelado. Na verdade, o conteúdo faz parte de uma matéria chamada fundamentos da química estrutural, que apesar de ser um pouco dificil, devido algumas coisas e nos mostra como tudo começou.

E é exatamente sobre isso que quero te contar hoje...

Sabia que existiu um físico londrino com bastante interesse pela química que lançou uma hipótese sobre os diferentes elementos? Pois é...

Essa pessoa chamava-se William Prout e após observar os pesos atômicos dos elementos, especulou que todos poderiam ser combinação do elemento primordial, que seria o hidrogênio.

No entanto, com todas as dificuldades para se explicar alguns fenômenos, essa hipótese durou um século, pois era muito bela e muito simples, na qual poderia conter alguma verdade.

É engraçado não é?! Se isso acontecesse agora, nos tempos de hoje, ninguém ia aceitar como explicação algo que não está completo... mas tudo bem!

O fato Fofão é que em 1913 apareceu um outro cara, Harry Moseley, que também era físico e trabalhava para o grande Rutherford (esse é famoso né?!). Ele utilizou uma técnica de espectroscopia dos raios-X e acabou descobrindo uma propriedade atômica, isto é, a carga nuclear, podendo se conhecer agora a ordem correta dos elementos da tabela periódica. Melhor que isso, foi possivel reservar um espaço, uma lacuna nessa tabela para os elementos que ainda não eram conhecidos. Fantástico não é?

Desse modo, esse jovem brilhante conseguiu dar o verdadeiro significado para o número atômico, sendo seu trabalho reconhecido pelos outros químicos, lógico que .

o Moseley... Já pensou eu descobrindo uma coisa nova que surpreendesse o mundo todo? Ai ai... Bom deixa eu continuar!

Apesar desse trabalho do Moseley, ainda haviam algumas questões perturbadoras, várias perguntas ainda continuavam a serem feitas, todas de por quê, por quê, por quê? Como quando a gente é criança e fica se perguntando sobre tudo a nossa volta.

Nosso grande Rutherford, junto com seu aluno exemplar, Moseley, se preocuparam principalmente com o núcleo do átomo, sua massa e sua unidade de carga elétrica.

Rutherford até propôs um modelo atômico em que os elétrons ficavam em órbitas ao redor do núcleo. Contudo, esse modelo não funcionava já que quando os elétrons perdiam energia eram engolidos pelo núcleo.

$\mathrm{E}$ foi por isso que em 1913, Niels Bohr conseguiu elaborar a teoria para o impossivel reunindo o modelo de Rutherforf com a teoria dos quanta de Planck. 
Olha só que interessante Fofão: a energia emitida ou absorvida pelo elétron era em forma de pacotes, os quanta, e não de forma continua. Essa idéia foi utilizada até pelo Einstein para explicar o efeito fotoelétrico.

Bohr utilizou essa idéia para contornar os problemas do modelo de Rutherford. Ele dizia que cada um dos orbitais possuía um nível de energia específico, isto é, um estado quântico. O menos energético (aquele que fica mais perto núcleo) é chamado estado fundamental.

Isso mostra que o elétron poderia saltar de um nível de energia para outro, embora sempre retornasse à sua casa, ou seja, ao seu estado fundamental.

Sendo assim, os elementos se organizavam naturalmente na tabela periódica e cada posição determinava a quantidade de elétrons em cada átomo. Essa tabela proposta por Bohr era igual à tabela empírica de Mendeleiev.

Simplesmente incrivel não é Fofão?

Por isso que a química seduz tanto. Esses mistérios e a dificuldade em resolvê-los deixa tudo muito mais interessante!

Estou cada vez mais apaixonada pelo meu curso...

Bom Fofão, agora eu tenho que ir estudar um pouco de matemática, que também faz parte da química. Mas eu espero que você tenha gostado dessa história sobre os átomos que eu acabei de te contar...

Aliás, tem outras coisas que ainda vou te contar, mas eu estou me informando mais. Deixa que eu te escrevo outro dia.

Beijão.

Obs.: Fofão é o nome que eu dou ao diário. 


\section{ANEXO E}

\section{Texto produzido pelo Aluno 3 referente ao capítulo 0 jardim de Mendeleiev}

Querido diário...

Você se lembra que eu disse que tinha mais coisa pra te contar né? Pois então! Dessa vez minha história é sobre a tabela periódica!

Os metais ocupam-na quase por inteira e são encontrados em todas as formas possiveis: bastões, nacos, cubos, filamentos, folhas, discos, cristais. A maioria cinzenta ou prateada, alguns com um leve toque de azul ou rosa. Alguns tinham um brilho amarelado, e os que mais chamam a atenção é o ouro e o cobre por causa das suas cores vivas.

No canto superior direito ficam os ametais, como o enxofre que se apresenta em cristais amarelos e o selênio em cristais vermelhos translúcidos. Tem também o oxigênio o qual é o gás essencial à nossa respiração que quando unido ao carbono formando $\mathrm{o}^{\mathrm{CO}_{2}}$ provoca o nosso temido efeito estufa.

Nessa tabela há 18 famílias e 7 períodos sendo que os elementos são distribuídos de acordo com a sua valência. Mendeleiev foi um dos primeiros a utilizá-la como base para a sua classificação. E sabe o que é mais fantástico Fofão? Todos os elementos se encaixam perfeitamente e apresentam as características previstas inicialmente.

E pensar que isso já vem de muito tempo... Primeiro com Lavoisier que definiu os elementos, depois com descoberta de Prout de que esses elementos se combinavam em proporções distintas e, é claro, com a idéia de Dalton de que os elementos tinham átomos com pesos atômicos únicos.

Nessa tabela, há famílias A e B. O número das famílias A indica quantos elétrons têm na camada de valência. Por exemplo: a $1 \mathrm{~A}$, cujos elementos são chamados de alcalinos e possuem apenas 1 elétron na camada de valência. Os elementos do $2^{\mathrm{a}}$, chamados alcalino-terrosos apresentam 2 elétrons e assim por diante. Ah! Os elementos da família 6A são chamados de calcogênios e da $7 \mathrm{~A}$ de halogênios (nomes estranhos não é fofão?!).

É claro que alguns elementos, principalmente aqueles descobertos mais tarde, eram dificeis de situar na tabela, como o tálio que ora se assemelhava ao chumbo, ora a prata ou o aluminio e às vezes ao potássio. Mas todos acabavam por achar o seu lugar.

Mendeleiev chegou até a reservar espaços na tabela para os elementos que ainda seriam descobertos. E foi mais além: dizia ainda algumas características dos mesmos como fusibilidade, gravidade específica...

Apesar de Mendeleiev ter feito toda uma estrutura, ele ainda desconhecia os gases nobres, que fazem parte, agora, da família $8 \mathrm{~A}$. O primeiro deles a ser descoberto foi o argônio, em 1814. E a princípio, Mendeleiev negou que ele fosse um elemento, mas depois tudo ficou evidente e foi achado um lugar para todos eles na tabela. 
O mais legal de tudo Fofão é um lugarzinho na tabela, na família 3B, em que temos uma série de elementos e não apenas um. Isso acontece porque eles são muito semelhantes e às vezes indistinguíveis em suas propriedades físico-químicas.

Super interessante essas histórias não é mesmo Fofão?! A tabela periódica é simplesmente fascinante, mesmo porque para tudo nela há uma explicação sendo que tudo se encaixa perfeitamente.

Sabe... Estou adorando entender todas aquelas coisas que são jogadas para nós no ensino fundamental! Super feliz.

Qualquer dia te conto mais sobre o meu curso.

Beijos...

Obs.: Fofão é o apelido que eu dou ao diário. 


\section{ANEXO F}

Texto produzido pelo Aluno 4 referente ao capitulo Luz brilhante

A luz que brilha

Olhe a sua volta quanta coisa bela!

Olhe para mim agora

É grafite, C com C temos que pensar fundo

Assim é feito o mundo!

Assim diz meus pensamentos

pois Deus criou a luz

quando fez-se os elementos

Mas quantos são eles?

São muitos? São poucos?

E se são tantos, de onde foi que vieram?

"Do mais simples", disse Prout

Que idéia genial

Aquele pequeno órfão

criou do dois ao centesimal

Mas isto está errado!!!

Provou Moseley com seu trem

De cato a catódico

Do raio-X criou-se o código

E o peso não é importante

quando existe algo a mais

os elementos vamos enumerar

cada qual com uma carga elementar

Mas os porquês não acabaram

Porquê? Porquê? Porquê?

Somos curiosos, não cansamos de mexer

Encontraremos algo para podermos entender

Olha só que fascinante

Esse pequeno sistema solar

um sol brilha no centro

com elétrons a radiar

Quem criou esse não foi Deus

foi cientista, Rutherford

Por isso, talvez, não deu certo

A energia dos planetas some

e do sol fica muito perto 
Mas não é por não ser Deus

É algo que iremos estudar pois com os mistérios da natureza vamos acabar

Quem sabe os quanta de Planck Seguiu Niels Bohr Planck de quanta? Que mundo é esse? Ora, não se lembra do que Planck falou: "A energia está a flutuar e os planetas a rodar quando querem ir para outro lugar um quanta de energia irão pega".

E o que era impossível se tornou real fazendo um mix genial unindo 'Ruth' aos quanta Seus pensamentos, Bohr canta:

Então mais músicas veremos do velho Niels Bohr contaremos quantos elétrons temos $\mathrm{E}$ vamos juntar o que sabemos

E assim como os prótons os elétrons a chegar Num sistema de tantas órbitas onde é que eles vão ficar?

Os primeiros lá no centro pertinho do "grande" núcleo E se mais planetas chegar Botem atrás, até bastar

E para cada átomo um número de acordo com o número de planetas um número para ele na tabela que coisa grandiosa aquela...!

Grandiosa de tão bela Bela de tão grandiosa Aquela era a lei da tabela as músicas de Moseley e Bohr estavam nela

E os pensamentos foram profundos

$\mathrm{Na}$ minha cabeça de jovem

A química comigo vem

E a luz que ilumina meus mundos 
E assim foi durante toda minha vida

Cercado de pensamentos, feito uma ilha

A química é minha querida

no fim do túnel é a luz que me brilha... 


\section{ANEXO G}

Texto produzido pelo Aluno 4 referente ao capitulo 0 jardim de Mendeleiev

O jardim

Flores e rosas

no mais belo jardim

da vida de um cientista

o jardim que grudou em mim

Margaridas à esquerda

ou à direita?

Vamos contar quantas

pétalas têm!

Mendeleiev, o jardineiro

o fez.

Quem sabe seja hora de começar

a plantar?

Sim, sim...

Mendeleiev esperto

Fez um bom trabalho

... excepcional

Fez de números e complicações

uma coisa simples

para cada átomo contou

as pétalas de valência

Arrumando o jardim assim

$\mathrm{E}$ belo ficou

Simples, organizado

como nenhum jardineiro

nunca fez

Sim está na hora de plantar...

Durante anos eu quis

Mas as atrofias

não deixaram

Que a porta do finado

museu se abrisse

São as mais belas

rosas, margaridas e violetas 
que já vi.

O mais impressionante

é o pré-dizer

isso é

Entre violetas e orquídeas

Uma planta irá nascer

Sei que será a flor de maio

Será simples de dizer

Seu caule é grosso

suas folhas escuras

Então 7 lindas pétalas há de ter

E o jardim me fascinara

em toda a sua extensão

subia onde ficava as rosas brancas

em que parte as raízes eram longas

ou quais eram as flores venenosas

Visitei-o por muitos dias

E ficava a admirar

feito um beija-flor noviço

não via o tempo passar

E o jardim era fantástico

naquela ordem periódica

um elemento na posição certa

Formando a tabela periódica. 


\title{
ANEXO H
}

Texto produzido pelo Aluno 5 referente ao capitulo $O$ jardim de Mendeleiev

\author{
Um passeio pelo jardim
}

Quem admira o jardim pronto

pode não se aperceber:

Organizá-lo levou tempo,

ficou bonito de se ver.

O primeiro passo dado rumo ao desconhecido: Séries de três elementos.

Eram canteiros divididos.

\begin{tabular}{|c|c|c|c|}
\hline $\mathrm{Ca}$ & $\mathrm{S}$ & $\mathrm{Li}$ & $\mathrm{Cl}$ \\
\hline $\mathrm{Sr}$ & $\mathrm{Se}$ & $\mathrm{Na}$ & $\mathrm{Br}$ \\
\hline $\mathrm{Ba}$ & $\mathrm{Te}$ & $\mathrm{K}$ & $\mathrm{I}$ \\
\hline
\end{tabular}

Como juntar estes canteiros?

Ninguém fazia idéia...

Quem resolveu o problema

foi um cara da Sibéria!

O jardim ganhou fileiras,

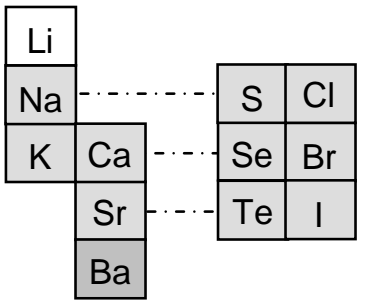
perceba as verticais:

Os elementos que as ocupam terão suas valências iguais.

O elemento logo abaixo, o pessoal tinha notado:

Se parece com o de cima, é só um primo mais pesado.

Alguns lugares ficaram vazios,

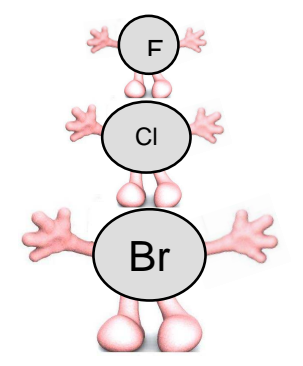
será que isto estava certo?

Esperando um elemento que ainda não fora descoberto.

Era possivel predizer cada um que ainda faltava mas a família dos gases nobres, esta foi inesperada!

\begin{tabular}{|c|c|c|c|}
\hline $\mathrm{V}$ & $\mathrm{Cr}$ & $\mathrm{M}$ & $\mathrm{Fe}$ \\
\hline $\mathrm{Nb}$ & $\mathrm{M}$ & $\substack{\text { HÁ } \\
\text { VAGAS }}$ & $\mathrm{Ru}$ \\
\hline $\mathrm{Ta}$ & $\mathrm{W}$ & $\mathrm{Re}$ & $\mathrm{Os}$ \\
\hline
\end{tabular}

O jardim só se completou quando vieram as terras-raras mas elas eram tão parecidas que foi difícil separá-las.

Quando o jardim estava pronto 
sobreveio uma surpresa:

A Ciência criou novos elementos, Desconhecidos na natureza.

O Urânio não é mais

o extremo dos canteiros, é o portal de outro jardim onde somos pioneiros. 


\section{ANEXO I}

\section{Texto produzido pelo Aluno 5 referente ao capitulo Luz brilhante}

Caro estudante de Química,

Há muito queria falar-lhe, mas peço que compreenda que me faltaram oportunidades. Me utilizo, portanto, deste meio pouco usual para chegar até você. Talvez não lhe seja familiar manter contatos desta maneira, mas estou convicto de que valerá a intenção.

Chegarão até você, mais cedo ou mais tarde, as teorias do século XX sobre a estrutura atômica. Você deve saber o quanto me interesso por elas, e espero que você também se interesse, mas não é apenas para introduzir-lhe nesse assunto que escrevo agora.

Tenho certeza de que você terá a oportunidade de aprender muita coisa sobre os átomos com seus professores e livros. Por isto mesmo eu prefiro tratar de um tema sobre o qual você via ouvir falar muito pouco, mas que foi a base de todo o avanço na compreensão do mundo que temos hoje: Eu gostaria de falar sobre a importância da criatividade para a ciência. Vou contar, para que sirva de exemplo, a minha própria história.

Quando eu era jovem como você, a ciência desconhecia muita coisa que sabemos hoje. A origem dos elementos químicos, por exemplo, era um mistério intocável. Sabiamos apenas que eles existiam e sabíamos organizá-los numa tabela periódica conforme suas propriedades. O motivo pelo qual estas propriedades variavam periodicamente parecia estar longe de ser esclarecido.

Foi justamente nesta época que eu tive a oportunidade de trabalhar com gente muito boa no que fazia. Um rapaz tão jovem quanto eu - seu nome era Moseley - acabara de sacudir a Química demonstrando que a propriedade fundamental de um elemento era a carga de seu núcleo, e não sua massa como todo mundo acreditava. A carga do núcleo aumentava em unidades discretas de um elemento para o seu sucessor na tabela periódica e esta unidade era a carga do elétron.

Refleti muito sobre este assunto. Percebi que todo elemento precisava ter um elétron a mais que seu anterior para neutralizar sua carga nuclear extra e foi inevitável para mim imaginar que estes elétrons ocupavam vagas com valores diferentes de energia potencial.

Muita gente criticou minhas teorias quando propus que o átomo de Hidrogênio era um sistema com um núcleo e um único elétron e a radiação emitida pelo Hidrogênio excitado era conseqüência do decaimento do elétron de uma vaga de maior energia potencial para uma de menor.

As críticas se concentravam no fato de eu acreditar que as leis da Física conhecidas não valiam no mundo angstrométrico do átomo. Parecia ousada demais, mas eu acabaria descobrindo que é justamente destas ousadias que a ciência é construída. Quando não conseguimos seguir adiante com aquilo que sabemos, é preciso desconfiar da existência de detalhes que desconhecemos e não hesitar em pensar com a própria cabeça. 
Foram necessários dez anos para reconhecer o valor das minhas idéias, mas eu acabei recebendo o Nobel por elas. Cinco anos mais tarde o surgimento de uma nova Física me absolveu definitivamente.

Minha teoria de que os elétrons se adicionavam ordenadamente aos átomos explicou a lógica da periodicidade na tabela. A idéia de que a radiação era absorvida e emitida devido a transições de elétrons serviu para decifrar o funcionamento do Sol e revelar a sintese dos elementos nos núcleos das estrelas.

Você, estudante de Química, terá a oportunidade rara de compreender o mundo. Não se contente apenas com as respostas que a ciência pode lhe dar: Explore por si mesmo os problemas sem solução. Não existe alegria maior do que o poder da descoberta.

Pode contar comigo, se você chamar, eu apareço.

Niels Bohr 


\section{ANEXO J}

\section{Texto produzido pelo Aluno 6 referente ao capitulo Luz brilhante}

\section{Princípios de Química}

Escolher pela carreira de química, a princípio, nos traz a idéia de um laboratório, com experimentos coloridos, nos quais saem fumaças e sempre resultam em uma conclusão eficaz. Tudo parede simples e ao mesmo tempo de grande responsabilidade. A imagem do químico se traduz a um jaleco e a um óculos de proteção.

Não está muito longe disso a imagem em que um aluno novato carrega ao iniciar sua graduação em química. Há uma grande ansiedade por saber qual será o ponto de partida de seu aprendizado, e a isso se mescla a vontade de conhecer e adquirir toda a teoria em pouco tempo, para que assim possa logo começar sua vida profissional.

Contudo, as primeiras aulas do curso causam um grande impacto, fazendo até com que o aluno pense que não é o curso que gostaria. Há mais aulas de matemática do que a própria química. O laboratório é seguido por um roteiro, no qual muitas vezes o aluno nem sabe o que está fazendo, e finalmente as aulas de química são muito complexas para quem acabou de sair de um ensino médio voltado apenas para o vestibular. Sendo assim a ansiedade dá lugar ao desespero.

Aos poucos, através de estudo, dúvidas e discussões, a matéria começa a ser compreendida, mesmo que ainda apareçam pontos conflituosos.

As aulas referentes a disciplina Fundamentos de Química Estrutural são as mais intrigantes, pois pertencem à estrutura microscópica, ou seja, não é possivel, a princípio, empregar o conteúdo no dia-a-dia, tornando assim de difícil visualização e portanto de dificil entendimento.

A rotina acaba trazendo aos alunos a normalidade da disciplina, e o que antes era impossivel, agora é fascinante. Entender apenas uma porcentagem do interior dos átomos já é algo indescritivel. Como foram feitas as descobertas, os experimentos, as inúmeras tentativas, os erros, os acertos, as previsões, tido gira em torno de apenas um eixo: a Tabela Periódica.

Para chegar nessa organização fundamental dos elementos tendo por base dados obtidos por muitos pesquisadores em um grande período, foram estabelecidos dois modelos: mecânica clássica e mecânica quântica, sendo que o insucesso do primeiro deu o início deste.

A mecânica clássica, na qual constam os modelos de Dalton, Thomson, Rutherford, Bohr, entre outros, foi um sucesso na explicação de várias forças nos movimentos de objetos, mas em contradição, não soube descrever o movimento de pequenas partículas, como os elétrons. Dessa maneira, a mecânica quântica surge como aperfeiçoamento e correção de alguns principios antes estabelecidos. Sendo assim, agora fica mais evidente a forma com que se ocorrem as ligações químicas. 
A compreensão da periodicidade da Tabela Periódica causa grande curiosidade entre os alunos iniciantes. É intrigante a forma com que os elementos se distribuem. Há perfeita harmonia entre o número atômico e a distribuição eletrônica, assim como a organização em grupos e períodos, conforme suas semelhanças. Tudo se torna interessante, há cada vez mais vontade de entender o interior dos átomos e o motivo de suas exceções. Além disso há ainda um dos pontos mais sensacionais na disciplina, que é a própria relação entre átomos, o modo como eles se unem e emitem espectros luminosos, assim como mudam seus estados físicos, suas propriedades e seu comportamento. Ocorre então, a base de toda pesquisa e teoria química.

Dessa forma, estabelece a relação entre as estruturas microscópicas e macroscópicas, sendo que estas dependem fundamentalmente das primeiras. Entender a capacidade de cada elemento torna-se um desafio. Desafio este que cada vez mais une os alunos a química, desmanchando a primeira imagem de laboratório e construindo em suas mentes um novo mundo, no qual é possível visualizar além do que seus olhos os permitem, ou seja, é possível descrever um comportamento microscópico, o qual ocorre a todo momento ao redor de todos. 


\section{ANEXO K}

\section{Texto produzido pelo Aluno 7 referente ao capitulo $O$ jardim de Mendeleiev}

Muitas pessoas acham que a profissão de Químico não tem muita importância ou que acham que se formam quimicos apenas para serem professores. Pois todos que têm essa idéia estão muito enganados.

A "Química" está muito mais presente no nosso dia-a-dia do que imaginamos. Desde as reações químicas que acontecem no nosso corpo (por exemplo o ar que respiramos nas células) à todas as outras que acontecem ao nosso redor (por exemplo o simples fato de abrir um refrigerante ou até mesmo água e a comida que nos sustentam) e também aquelas mais sofisticadas como por exemplo a manipulação de um novo fármaco ou o lançamento de um iogurte.

Como vimos, tudo o que acontece no Universo, podemos olhar com olhos de químicos. Mas para que todas as reações aconteçam, foi necessário um dia descobrirem os elementos químicos e suas características. No entanto, isso levou um grande tempo, pois não foi necessário apenas descobri-los, mas também foi necessário organizá-los. Para isso muitos cientistas, quimicos e fisicos tiveram que gastar longas horas em seus experimentos para chegar no que conhecemos como "TABELA PERIÓDICA".

Esta tão poderosa arma dos cientistas é como se fosse nossa lista telefônica. Nela encontramos o "endereço" de cada elemento químico. Encontramos por exemplo o seu nome, o seu símbolo, o seu número atômico, o seu número de massa entre outras informações. Se procurarmos o elemento de hidrogênio na tabela periódica encontraremos:

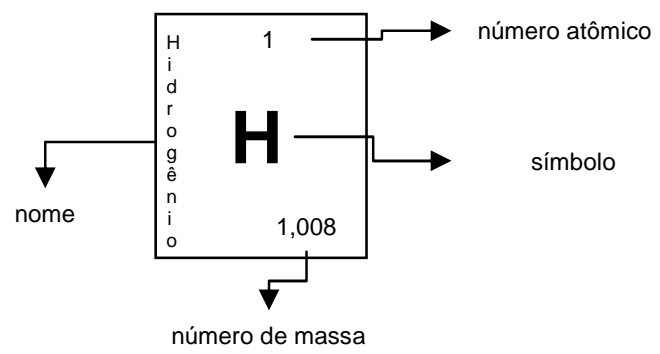

Atualmente, sabe-se que existe por volta de 118 elementos químicos (entre naturais e artificiais).

O elementos estão dispostos em ordem crescente do número atômico e do número de massa (com exceções). Podemos também dispô-los em tamanho do raio atômico, o valor da energia de ligação, da eletronegatividade entre outros.

Há muitos outros estudos mais aprofundados sobre os elementos. Ao fazer a distribuição eletrônica de um elemento químico, podemos identificá-lo na tabela periódica e saber todas as suas características. Por exemplo, um elemento que tem a seguinte configuração: $1 s^{2}-2 s^{2}-2 p^{6}-3 s^{2}$ $-3 p^{6}-4 s^{2}-3 d^{10}-4 p^{6}-5 s^{2}-4 d^{8}$. Somando seus números atômicos temos 
46. Sabemos que ele pertence aos elementos de transição pois termina com o subnível "d" e está no $4^{\circ}$ período e que está na $8^{a}$ família dos elementos de transição. Com tais características, buscamos na tabela periódica e encontramos o elemento químico "PALÁDIO". Podemos ir um pouco mais além e descobrir que na sua camada de valência existem 16 elétrons $\left(4 s^{2}-\right.$ $\left.4 p^{6}-4 d^{8}\right)$ e que seus elétrons estão distribuídos da seguinte forma em seus orbitais:

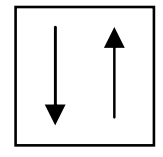

$4 s^{2}$

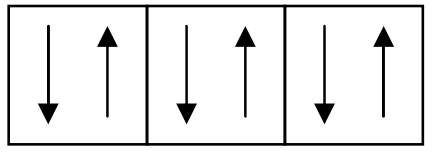

$4 p^{6}$

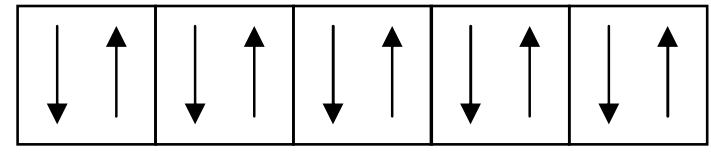

$4 d^{8}$

Com essas informações, podemos descobrir também, que tipo de ligação o elemento faz, com quem ele pode se ligar, qual o composto que formará entre outros.

Sabendo tudo isso, os químicos podem ajudar em muito (ou até mesmo prejudicar) a humanidade. Podem descobrir qual substância seria eficaz ao combate da AIDS e assim compor um novo remédio, descobrir qual substância que é mais resistente a um material ou até mesmo (infelizmente) manipular um veneno.

Esperamos que o homem use todas essas poderosas ferramentas apenas para ajudar a si próprios e esquecer todo o ma que pode causar. 


\title{
ANEXO L
}

\section{Texto produzido pelo Aluno 8 referente ao capitulo Luz brilhante}

\author{
Espetáculo quântico
}

Os séculos XIX e XX foram, sem dúvidas, dos mais produtivos no campo das ciências da natureza. Mais especificamente no final do século XIX e início do século XX ocorreram as mais significativas mudanças nas teorias das ciências. Foi em 1900, após um bom tempo de impasses e discussões improdutivas, devido às amarras da física clássica, que um cientista chamado Max Planck resolveu inovar. O problema em questão era: Como associar o aumento da emissão de altas freqüências num corpo negro com o aumento da temperatura?

Um corpo-negro é um objeto que emite toda energia que nele é incidida. A física de Planck não explicava essa emissão porque segundo as leis vigentes qualquer objeto que tivesse energia (ou seja, corpos que não estão a $0 \mathrm{~K}$ ) deveria emitir radiação ultravioleta. Então Planck postulou que a troca de energia entre ondas eletromagnéticas e átomos não deveria ocorrer continuamente, mas sim discretamente por meio de pequenos pacotes de energia. Este pacote de energia chamaria-se quantum e cada quantum deveria ser portador de uma energia $E=h v$, onde $h$ é chamada de constante de Planck, determinada empiricamente, e $v$ é a freqüência da onda emitida. Então se energia $\mathrm{E}$ é fornecida por aquecimento a um corpo-negro, o mesmo deve emitir uma onda de freqüência $\mathrm{E} / \mathrm{h}$, pois a maioria dos átomos de corpo-negro teria agora uma energia maior E. Assim Planck explicou a emissão num corpo negro e evitou a catástrofe ultravioleta, mas não somente isso, abriu também novas portas para a interpretação do mundo dos átomos e, conseqüentemente, nosso mundo. $\mathrm{O}$ primeiro grande trabalho baseado na teoria de Planck foi de Albert Einstein, para o efeito fotoelétrico, em 1905.

O efeito fotoelétrico consiste na emissão de elétrons de uma superficie metálica pela incidência de ondas eletromagnéticas sobre essa superficie. $O$ que era observado e ainda não se tinha explicações era: A emissão dos elétrons somente ocorria a partir de uma determinada freqüência das ondas incidentes, e não aumentava conforme aumentava a freqüência, aumentava somente se a intensidade da onda era aumentada. $\mathrm{O}$ aumento da freqüência somente aumentava a energia cinética do elétron ejetado.

A explicação de Einstein, que lhe rendeu o prêmio Nobel daquele ano, foi que as ondas eletromagnéticas seriam compostas por partículas chamadas fótons. Cada fóton teria uma energia $\mathrm{E}=\mathrm{h} v$. Então, quando ondas eletromagnéticas são incididas numa superficie metálica, faz-se fótons chocarem-se contra os elétrons do metal. Assim, se o elétron receber energia suficiente, ele saltará da superfície metálica. Caso contrário, continua no metal. Então, conforme aumenta-se a freqüência da onda, aumenta-se a energia do fóton que irá chocar-se com o elétron e retirá-lo do metal com energia cinética cada vez maior. Uma vez que aumenta-se a intensidade da onda, aumenta-se o $\mathrm{n}^{\mathrm{o}}$ de fótons que irão se chocar, ou seja, com mais 
colisões terá também um maior $\mathrm{n}^{\circ}$ de elétrons ejetados. Esse resultado é utilizado em células fotoelétricas para automação de sistemas dependentes da luz do dia, como postes, controles-remoto e até mesmo para a geração de energia elétrica por meio de raios solares.

Mas não foi só essa a conseqüência de Planck. Foi Niels Bohr que deu ao quantum uma fantástica interpretação. Bohr uniu o modelo atômico desenvolvido por Rutherford com a teoria dos quanta de Planck e a dualidade onda-partícula de De Broglie. Segundo Bohr o átomo seria composto por um núcleo positivo muito denso e pequeno. Os elétrons ocupariam niveis de energia em torno do núcleo. Ou seja, um elétron não poderia ter qualquer energia, mas sim múltiplos de uma energia fundamental. Então, para ele, o momento angular do elétron seria quantizado. O interessante desta teoria é que nos diz também a respeito da luminescência e das cores do espectro de emissão. Segundo seu modelo, um elétron inicialmente encontra-se em seu estado de menor energia, denominado fundamental. Após receber certa quantidade de energia, o elétron poderia realizar "saltos", ou seja, passar a ocupar niveis mais energéticos, e após isso retornaria ao seu nível fundamental e emitiria um fóton com a mesma energia que o fez saltar. Sendo assim, com o sódio, por exemplo, ao colocarmos um sal seu numa chama, observariamos uma coloração amarelada na chama, que seria resultante do recebimento de energia, pelos elétrons, do fogo, e conseqüente retorno do elétron ao seu estado fundamental com a emissão de um fóton na freqüência do amarelo. Assim, cada sal de metal emite uma cor ao ser aquecido e este fato é utilizado, por exemplo nos fogos de artificio, que não são nada menos do que pólvora com sais de diferentes metais. Quando a pólvora queima, libera energia suficiente para possibilitar o salto dos elétrons nos átomos dos metais, proporcionando-nos assim um verdadeiro espetáculo quântico. 


\section{ANEXO M}

\section{Texto produzido pelo Aluno 9 referente ao capitulo 0 jardim de Mendeleiev}

São Carlos, abril de 2007

Caro colega,

Queria felicitá-lo pelo ingresso em uma das maiores universidades do Brasil. Pode parecer estranho o que vou te dizer, mas é a verdade que deve guiar seus pensamentos, entrar é a parte mais fácil, dificil é conseguir acompanhar o ritmo de estudos impresso, principalmente no primeiro semestre. Esse é o momento em que muitos desistem, porém é essencial ter garra e fé que tudo pode ser melhorado.

Soube também o curso escolhido: química. Então vou tentar deixar claro os princípios da tabela periódica, sua companheira de todas as horas a partir de agora.

A tabela é dividida em 18 grupos ou famílias, os membros de cada família possuem configurações eletrônicas de valências idênticas.

Muitas propriedades variam no sentido horizontal e vou descrever detalhadamente para você.

Os elementos podem ser metais, não metais e semi-metais, tendo em vista a condutividade elétrica.

Os não metais são considerados isolantes elétricos. Os semi-metais possuem pequena condutividade, mas é mensural e aumenta com a temperatura. E pode-se concluir que os metais são condutores e na maioria dúcteis e maleáveis.

$\mathrm{Na}$ tabela os elementos metálicos aparecem do lado esquerdo e são separados por uma linha diagonal de semi-metais que vai do boro ao telúrio. E após estes fica complicada a classificação, pois os elementos dos grupos 14,15 e 16 aparecem em formas alotrópicas, cada qual com propriedades diferentes. Sendo assim, os elementos não podem ser classificados exclusivamente em um único tipo, sem mencionar a variação alotrópica do elemento.

Esta não é a única propriedade, então passemos às próximas.

A energia de ionização tende a aumentar com o raio atômico, e o comportamento metálico está relacionado com os elementos de baixa energia de ionização e consequentemente, o aumento dessa energia no sentido da esquerda para direita ao longo do periodo faz com que haja a perda de caráter metálico.

Já para a família a energia tende a diminuir com o aumento do número atômico. Isto é, mais claro entre os elementos representativos e se relaciona com o aparecimento de propriedades metálicas que ocorrem a medida que os números atômicos aumentam no grupo.

Porém é mais difícil falar a respeito do comportamento periódico das afinidades eletrônicas, são maiores nos halogênios e menores nos alcalinos. 
A variação da energia de ionização e a afinidade eletrônica com o número atômico deixa claro que os não metais tem tendência de adquirir elétrons.

O oposto, perder elétrons, tem o nome de eletronegatividade. A escala mais utilizada e comum é a que foi proposta por L. Pauling, baseada em energias de ligação. É sabido que a energia do $\mathrm{H}-\mathrm{Cl}$ é maior que a média do $\mathrm{H}_{2}$ e $\mathrm{Cl}_{2}$.

Ele imaginou que esse aumento seria a diferença de eletronegatividade do $\mathrm{H}$ e do $\mathrm{Cl}$ e poderia ser atribuído ao caráter iônico da ligação $\mathrm{HCl}$ e as contribuições iônicas nos casos do $\mathrm{H}_{2}$ e $\mathrm{Cl}_{2}$ seriam nulas.

Uma outra definição de eletronegatividade proposta por R. S. Mulliken propôs que seria a média da energia de ionização com a afinidade eletrônica.

A variação ocorre numa família, os átomos maiores são mais eletronegativos que os grandes. Isso faz com que o flúor seja o elemento mais eletronegativo. Pode-se perceber ainda que os átomos com eletronegatividades parecidas estão dispostos na diagonal.

Passemos ao tamanho do átomo. A variação periódica no tamanho atômico foi notada primeiramente por Lothar Meyer em 1870. Calculou o volume atômico de um elemento dividindo o peso atômico por sua densidade. E colocando no gráfico esse volume aparente em função do número o resultado é uma curva com formato de serra. Quando calculado deste modo é, na melhor das hipóteses, uma indicação qualitativa, pois a densidade depende da temperatura e estrutura cristalina. E os que possuem mais de uma forma de cristalinos pode ter mais de um volume atômico.

Há também o fato de a nuvem eletrônica de um átomo não poder ser definida de forma simples. Entretanto, a única medida válida de tamanho atômico é o parâmetro de Lennard-Jones, que representa a distância de maior aproximação dos núcleos de dois átomos livres, gasosos, do mesmo elemento. Fica claro que na família, o raio atômico aumenta com o número atômico. Contudo no período o tamanho diminui com o aumento do número atômico. Ambas as tendências são esperadas com base nas mudanças na estrutura eletrônica. A medida que o número atômico aumenta em uma dada família, o número quântico principal dos elétrons de valência aumenta, e conseqüentemente esses elétrons ficam a distâncias crescentes do núcleo. Ao longo de um dado período da tabela periódica, o número quântico é constante, porém a carga nuclear aumenta, os elétrons tendem a ficar mais próximos do núcleo.

Outra forma quantitativa, mas útil na compreensão das propriedades químicas é o raio iônico e sugerimos como eles estão relacionados com a geometria do cristal. Entretanto só darei ênfase às tendências regulares no tamanho atômico que ocorrem na tabela periódica.

Pode ser notado para qualquer seqüência isoeletrônica, isto é, para qualquer série de íons que apresentam o mesmo número de elétrons, o raio iônico diminui a medida que o número atômico aumenta.

Vou relatar algumas idéias importantes sobre óxidos e hidretos.

A maioria dos elementos formam óxidos. São todos estáveis com respeito aos elementos, com exceção de óxidos de nitrogênios e dos halogênios. Os óxidos metálicos, tais como os dos grupos 1 e 2, são básicos, os formados pelos grupos 15, 16 e 17 são ácidos e os formados pela diagonal que vai do berílio ao chumbo são anfóteros. Os hidretos podem ser 
classificados como iônico, covalente, ou do tipo metal de transição. Os hidretos iônicos apresentam o íon $\mathrm{H}^{-}$e constituem sólidos cristalinos bastante reativos. Muitos hidretos covalentes formam pontes de hidrogênio em fase condensada. A ligação de hidrogênio na água determina as propriedades do gelo e da água líquida. As estabilidades dos óxidos e dos hidretos dos elementos representativos são consistentes com as eletronegatividades de Pauling.

Já vimos as propriedades da tabela, mas também é importante saber como os átomos se ligam.

Existem basicamente 2 tipos de ligação: a iônica e a covalente.

Para ocorrer um ligação iônica é preciso que haja uma grande diferença na eletronegatividade dos elementos envolvidos. Normalmente ocorre entre um metal e um ametal.

Os sais são um bom exemplo desse tipo de ligação.

A ligação covalente ocorre entre os não metais, pois estes apresentam baixa diferença na eletronegatividade.

A maioria dos compostos orgânicos apresentam este tipo de ligação.

A ligação covalente pode ser ainda dividida em polar e apolar.

Para uma molécula ser apolar é necessário que a soma dos momentos dipolo seja igual a zero.

Pode-se presumir que para ser polar é preciso que o momento dipolo seja diferente de zero.

Só não podemos confundir ligação polar com molécula polar. Uma molécula pode possuir somente ligações polares e no conjunto ser apolar. Um bom exemplo é o $\mathrm{CO}_{2}$.

Existem muitas teorias para explicar o compartilhamento dos pares eletrônicos em ligações covalentes, mas não vou explicá-las, pois necessita que você tenha conhecimento um pouco profundo sobre mecânica quântica. Vou, portanto, apenas citá-las, teoria dos orbitais moleculares e teoria da ligação de valência.

Acho que escrevi demais, em todo o caso desejo sorte e que esta pequena carta lhe ajude em algo no futuro. 


\section{ANEXO N}

\section{Texto produzido pelo Aluno 10 referente ao capitulo Luz brilhante}

Em 1815, cerca de cinqüenta elementos eram conhecidos e segundo Dalton isso implicaria em cinqüenta tipos diferentes de átomos. Especulava-se que o hidrogênio era o elemento primordial e que todos os outros foram construídos a partir dele, pois William Prout, físico com interesse em química, observou que os pesos atômicos eram múltiplos do peso atômico do hidrogênio. No entanto, alguns elementos apresentavam pesos atômicos fracionários e só podia-se arredondar os pesos que fossem ligeiramente menor ou maior que um número inteiro. Isso dificultou a aceitação da idéia de Prout, e essa dificuldade só aumentou quando Mendeleiev elaborou a tabela periódica; elementos, no aspecto químico, vinham antes e, no peso atômico, vinham depois. Apesar desses grandes obstáculos, a hipótese de Prout nunca foi esquecida e mais adiante veremos que foi comprovada.

Em 1913, Harry Moseley, um físico que trabalhava com Rutherford, começou a investigar o núcleo dos átomos através da espectroscopia de raios $\mathrm{X}$, bombardeando cada elemento com raios catódicos, fazendo com que emitissem raios X definidos. Moseley "graficou" as freqüências desses raios, obtendo uma reta; ao marcar os pontos inversamente demonstrava-se que o aumento na freqüência indicava "saltos" nítidos quando passava de um elemento para outro. Assim Moseley concluiu que esse fato refletia uma propriedade fundamental, a carga nuclear.

A partir dai passou-se a identificar cada elemento através da sua carga nuclear, o número atômico, única. Ao dispor os elementos na seqüência crescente de número atômico não deveria existir nenhuma lacuna, pois isso significaria que estava faltando um elemento. Com isso, as "anomalias" causadas pelo peso atômico foram solucionadas; o que importava era o número atômico.

Ainda que Moseley tenha mostrado a quantidade a posição dos elementos, outras dúvidas fundamentais permaneciam e que posteriormente seriam respondidas.

Rutherford e Moseley dedicaram-se aos estudos do núcleo do átomo, sua massa e carga elétrica. Mas eram os elétrons em órbita, sua organização e ligações que determinavam as propriedades físicas e químicas dos elementos. E é nesse aspecto do estudo do átomo que o modelo de Rutherford se desestabilizava, pois segundo a física clássica, um átomo semelhante a um sistema solar não era viável, porque os elétrons em órbita ao redor do núcleo com velocidade altíssima gerariam uma radiação em forma de luz visível.

Fazia-se necessário apelar para princípios novos que eram capazes de conciliar essa inviabilidade.

Foi Niels Bohr, que também trabalhava no laboratório de Rutherford no mesmo período, quem uniu o modelo de Rutherford à nova teoria fisica de Planck, dos quanta. Havia sido deixada de lado a idéia de que a energia era absorvida ou emitida de forma não contínua, desde 1900. Albert Einstein 
utiliza essa idéia na explicação do efeito fotoelétrico, mas ainda assim essa teoria de Planck era ignorada até que Bohr a utilizasse para reverter as inviabilidades do modelo de Rutherford. Bohr postulou um átomo com número limitado de órbitas, cada uma com nível energético específico; o menos energético foi chamado de "estado fundamental", onde o elétron podia permanecer em órbita sem emitir ou perder energia. Postulou também que haviam órbitas de maior energia, os "estados estacionários" de maior energia, para onde os elétrons podiam momentaneamente se deslocar; quando um átomo absorvesse energia, um elétron podia passar do seu estado fundamental para outro de maior energia, e, ao retornar, emitiria energia de mesma freqüência que absorveu.

Para Bohr, os intervalos entre niveis de energia diminuiam com a distância do núcleo e calculou que correspondiam às linhas no espectro de hidrogênio. Essa coincidência foi a primeira vitória de Niels Bohr.

Com o aumento do número atômico (o número de prótons no núcleo), um mesmo numero de elétrons deveria ser acrescentado, afim de preservar a neutralidade do átomo, de maneira organizada. Bohr ampliou os estudos das órbitas do hidrogênio para todos os elementos. Essas órbitas tinham níveis energéticos definidos, dessa forma, se os elétrons fossem adicionados um de cada vez, ocupariam primeiro a órbita de menor energia, e assim sucessivamente. Esses eram os periodos de Mendeleiev, estudados a partir de outro raciocínio.

A posição de cada elemento na tabela periódica representava o número de elétrons dos átomos, e a reatividade e ligações de cada elemento podiam ser analisados de acordo com o preenchimento da camada de valência; o que acabou explicando a quase total não reatividade dos gases inertes, uma vez que têm completos 8 elétrons na camada de valência.

A localização dos elementos de transição externa e interna na tabela causaram problemas. Então Bohr propôs que os elementos de transição continham uma camada adicional de dez elétrons (nd ${ }^{10}$ ) e os de transição interna de catorze $\left(\mathrm{nf}^{14}\right)$.

A tabela periódica segundo as características eletrônicas de Bohr, baseada na estrutura atômica, era igual à tabela empírica de Mendeleiev, baseada na reatividade química. Moseley e Bohr deixaram claro que a tabela tinha uma série numérica fundamental, o que determinava a quantidade de elementos em cada período (linha), $(2,8,8,18,18,32)$. As características de cada elemento podiam ser explicadas e determinadas ou sugeridas através de seus números atômicos. Por exemplo, algumas propriedades dos metais, como as densidades a altos pontos de fusão eram explicados de acordo com a intensidade com que os elétrons estavam ligados ao núcleo. Um átomo intensamente ligado correspondia a dureza e densidade e alto ponto de fusão, típicos dos metais. Já a condutividade foi atribuída a uma nuvem de elétrons livres de grande mobilidade, o que também explicava seu brilho, pois oscilavam sob o impacto da luz e se dispersavam ou refletiam a luz.

Outra questão fascinante era com relação à natureza dual da luz, comportamento de onda e partícula. A luz ou a radiação apresentavam-se em unidades minimas, ou quanta (pacotes discretos de energia), cuja energia depende de sua freqüência. Um quantum de luz de comprimento curto, da luz violeta por exemplo, tinha mais energia que um vermelho, e um quantum 
de raios tinha ainda mais energia. Cada tipo de átomo ou molécula requer uma certa quantidade específica de energia para gerar uma resposta. Toda luz provem de átomos ou moléculas que foram excitados e retornaram ao seu estado fundamental, liberando o excesso de energia na forma de radiação visível.

No entanto o sol e as estrelas não são como as luzes da Terra. E podemos concluir que sua temperatura superficial era de cerca de 6000 graus. Sabe-se também que grande parte das reações químicas cessam acima de 1000 graus. Em 1929, uma nova idéia surgiu: devido às altíssimas temperatura e pressão do interior de uma estrela, átomos poderiam fundir-se uns com os outros, gerando átomos mais pesados, o que levou à conclusão de que a fonte de energia das estrelas é termonuclear. Explicamos o processo da seguinte maneira: diante de temperaturas e pressões tão altas, os núcleos dos átomos, desprovidos de seus elétrons, deslocam-se, a velocidades muito altas, e freqüentemente colidem-se um contra os outros, fundindo-se, e originando elementos mais pesados. A conversão e hidrogênio $(Z=1)$ em hélio $(Z=2)$ produz imensa quantidade de calor e luz, e a energia gerada pelo sol, a cada segundo consumia centenas de milhões de toneladas de hidrogênio convertidas em hélio, mas como sua massa é imensa, apenas uma pequena fração do hidrogênio que o compõe foi consumido.

A conversão do hidrogênio em hélio possibilita concluir que, na presença de calor e pressão suficiente, podiam-se fundir e formar elementos mais pesados e assim sucessivamente.

O hidrogênio, primeiro elemento da tabela periódica, era sim o átomo essencial e primordial do universo, como propusera Prout em 1815, o ponto inicial dessa dissertação. 


\section{ANEXO O}

\section{Texto produzido pelo Aluno 11 referente ao capitulo 0 jardim de Mendeleiev}

Já teve a oportunidade de ver quão diferentes e fascinantes são os elementos, mesmo que seja só na aparência? Se não, não sabe o que está perdendo como químico.

Definiremos, neste texto, algumas propriedades da tabela periódica e como foram desenvolvidas. A princípio, deve ser salientado a importância da valência, termo definido adequadamente em 1850, apresentando, para valência, um caráter racional, uma base para que eles possam formar famílias e servir como base para analogias químicas e físicas.

A valência segue em ordem crescente acompanhando seu grupo (valência 1 no grupo I - valência 8 no grupo VIII).

Mendeleiev observou que a classificação por valência coincidiu com o peso atômico. Após montada a tabela, pode-se observar que cada elemento imita as propriedades do elemento acima e é um pouco mais pesado.

Com relação à parte histórica do seu desenvolvimento, Mendeleiev demorou quase vinte anos para se aplicar na classificação da tabela, período o qual pode ser marcado por reflexão e incubação, o que explica o conhecimento demonstrado por ele ao publicar "Principios de Química".

Mendeleiev apresentou uma tabulação de trinta e tantos elementos, porém, conta-se que na noite de 16 de fevereiro de 1869, Mendeleiev teve um sonho no qual viu todos os elementos conhecidos organizados numa grande tabela. Na manhã seguinte, ele pôs no papel.

Após mudanças que foram questionadas por muitos, Mendeleiev pôde até prever as propriedades do desconhecido gálio. De sonhador, Mendeleiev foi considerado o descobridor da tabela periódica e seus elementos.

O grupo referente aos gases nobres só veio a ser descoberto posteriormente com a descoberta do Argônio, que fez com que percebêssemos a necessidade de existir um grupo entre os halogênios e alcalinos.

Outro problema na determinação da tabela periódica foi os elementos de terras raras, os quais eram dificeis de serem achados. Isso gerou inúmeras tentativas de tabela, só para se ter idéia mais de cem foram feitas enquanto Mendeleiev era vivo.

Um fato interessante e fascinante são os elementos transurânicos, os quais são novos e não se sabe até qual número atômico pode chegar, parecendo ser indeterminado.

Através desta resumida historia, pode-se comprovar a real importância dos fatos representados na tabela, verdades, até agora, fortes e, aparentemente, irrefutáveis. 


\section{ANEXO P}

\section{Texto produzido pelo Aluno 12 referente ao capitulo Luz brilhante}

Em 1815 eram conhecidos aproximadamente cinqüenta elementos, e segundo Dalton haviam então cinqüenta tipos diferentes de átomos. Mais tarde, o cientista William Prout observou que o peso atômico dos átomos eram próximos de números inteiros e, portanto, múltiplos do peso atômico do hidrogênio. Logo propôs que o hidrogênio era a base dos elementos, e todos os outros teriam sido feitos a partir dele. Porém alguns elementos tinham pesos fracionários, os quais não podiam ser arredondados como os que eram ligeiramente menores ou maiores que o número inteiro. As dificuldades de sustentar a hipótese de Prout foram agravadas quando Mendeleiev elaborou a tabela periódica, onde o telúrio, por exemplo, vinha antes do iodo, mas seu peso atômico era maior, e não menor.

Em 1913, Harry Moseley começou a investigar átomos com a recém desenvolvida técnica da espectroscopia de raios $X$, onde Moseley bombardeava cada elemento, no vácuo, com raios catódicos, fazendo com que emitissem raios $\mathrm{X}$ característicos. Moseley fez um gráfico das raízes quadradas das freqüências em relação ao número atômico, e obteve uma reta. Ao marcar inversamente os pontos, ele demonstrou que o aumento na freqüência indicava passos nítidos e discretos, ou saltos quando passava ao elemento seguinte. Moseley julgou que isto era uma propriedade atômica fundamental, e esta só poderia ser a carga nuclear.

Com isto, determinou-se com certeza a ordem dos elementos, onde a presença de alguma lacuna indicava a falta de um elemento, e sabia-se que havia 92 elementos e estava claro que faltavam sete elementos, e mais nenhum. Logo as dificuldades quanto ao peso atômico foram resolvidas, como no caso do iodo e do telúrio, com a determinação de que o que importava era o $\mathrm{n}^{\circ}$ atômico e não o peso atômico.

Os números atômicos, usados anteriormente para denotar a seqüência ordinal dos elementos classificados segundo seu peso atômico, agora indicavam a carga nuclear, a identidade do elemento, de um modo absoluto e certo.

Rutherford e Moseley imaginavam, eram os elétrons em órbita, sua organização, suas ligações, que determinavam as propriedades químicas de um elemento, e também muitas de suas propriedades físicas. E, com os elétrons, o modelo do átomo de Rutherford "afundava". Segundo a física clássica, um átomo assemelhado a um sistema solar, não poderia funcionar, pois os elétrons girando ao redor do núcleo milhares de vezes por segundo criariam radiação em forma de luz visivel, e um átomo assim emitiria uma centelha de luz momentânea e então implodiria quando seus elétrons, tendo perdido a energia, seriam impelidos para o núcleo.

Na mesma época, Niels Bohr reuniu o modelo atômico de Rutherford à teoria dos quanta de Planck, de que a energia era absorvida ou emitida não de maneira contínua, mas em pacotes discretos, os quanta. Essa teoria foi usada por Einstein no contexto dos efeitos fotoelétricos, e Bohr a empregou para contornar as impossibilidades do átomo de Rutherford. 
O sistema solar atômico, com sua infinidade de órbitas e seus elétrons emitindo energia não era capaz de produzir as linhas espectrais discretas dos elementos, mas apenas um espectro contínuo. Bohr então afirmou um átomo com um número limitado de órbitas discretas, cada qual com um nível de energia específico, ou estado quântico. O menos energético destes, o mais próximo do núcleo, Bohr denominou de "estado fundamental", onde um elétron podia permanecer, orbitando o núcleo, sem emitir ou perder energia, para sempre. Junto a isso, Bohr afirmou também que haviam órbitas de maior energia, estados estacionários, de maior energia, para os quais os elétrons podiam ser brevemente deslocados, com uma absorção de energia sofrida pelo átomo, e retornariam com a emissão da mesma quantidade de energia, o que explicava as linhas de absorção e a emissão espectral.

Conforme aumentava a carga nuclear, um número igual de elétrons tinha que ser acrescentado para preservar a neutralidade do átomo. Segundo Bohr, esses elétrons ocupariam camadas com niveis de energia discretos, e se fossem adicionados um a um, ocupariam primeiro a órbita de menor energia disponivel.

As camadas de Bohr correspondiam aos períodos de Mendeleiev, onde a camada mais interna acomodava somente dois elétrons, e assim que esta fosse completada, começaria uma segunda com oito elétrons. O mesmo ocorria para o terceiro período.

Por meio desta conformação, denominada aufbau, para Bohr todos os elementos podiam ser naturalmente inseridos em seu lugar na tabela periódica. 